Joel Dias Pinheiro Filho

\title{
DEGRADAÇÃO DE ALQUILBENZENO LINEAR SULFONADO EM REATOR ANAERÓBIO OPERADO EM BATELADAS SEQÜENCIAIS COM BIOMASSA IMOBILIZADA EM CARVÃO
}

\section{VEGETAL}

Dissertação apresentada à Escola de Engenharia de São Carlos da Universidade de São Paulo, como parte dos requisitos para a obtenção do Título de Mestre em Hidráulica e Saneamento.

Orientadora: Maria Bernadete Amâncio Varesche Silva

São Carlos 


\section{AUTORIZO A REPRODUÇÃO E DIVULGAÇÃO TOTAL OU PARCIAL DESTE TRABALHO, POR QUALQUER MEIO CONVENCIONAL OU ELETRÔNICO, PARA FINS DE ESTUDO E PESQUISA, DESDE QUE CITADA A FONTE.}

Ficha catalográfica preparada pela Seção de Tratamento da Informação do Serviço de Biblioteca - EESC/USP

P654d

Pinheiro Filho, Joel Dias

Degradação de alquilbenzeno linear sulfonado em reator anaeróbio operado em bateladas seqüenciais com biomassa. imobilizada em carvão vegetal / Joel Dias Pinheiro Filho ; orientador Maria Bernadete Amâncio Varesche Silva. -São Carlos, 2008.

Dissertação (Mestrado-Programa de Pós-Graduação e Área de Concentração em Hidráulica e Saneamento) -- Escola de Engenharia de são Carlos da Universidade de São Paulo, 2008.

1. Saneamento. 2. Absorção. 3. Carvão vegetal. 4. LAS. 5. Surfactante. I. Título. 
Candidate: Bacharel JOEL DIAS PINTIE.IRO FILIIO

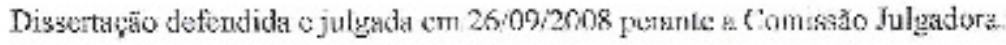

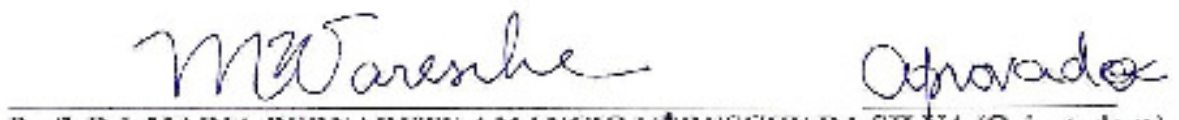

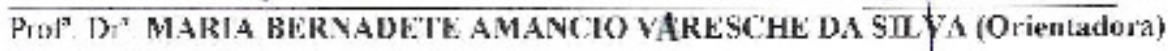
(Tscola de Tngenharin de Săo Carlos LASP)

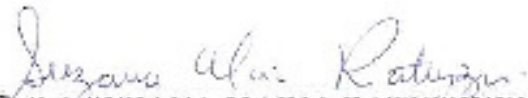

PrOf. Di $\mathrm{L}^{-1}$ SIIZANA MARIA RATUSZNEI

(Fuciala de Fnusenharia de Mang/F.FM)

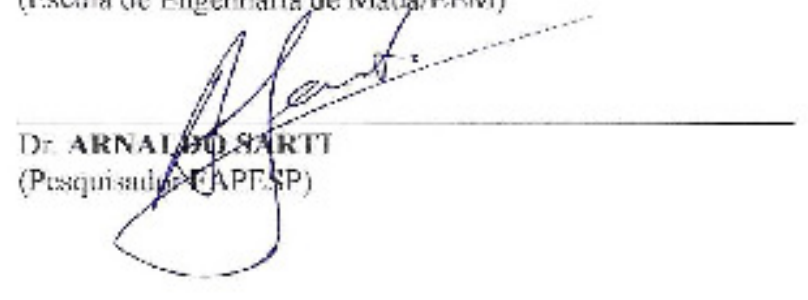

AYMOUALO

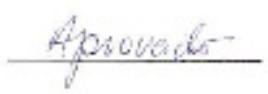

$(\ldots, \ldots$

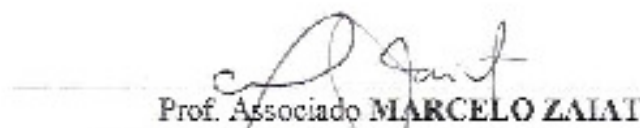

Conodenador do Progranna de Pós-Graduação cm

Engenharia (Hidráulica Saneamento)

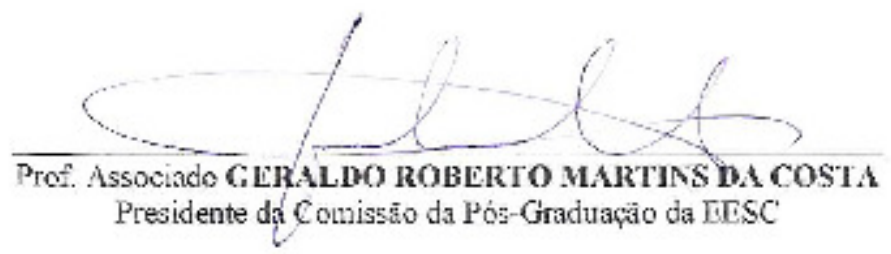



A Joel e Maria Lúcia, exemplo de pais dedicados, que muito trabalharam para proporcionar a seus filhos Educação, bem libertador maior. 



\section{AGRADECIMENTOS}

À Profa. Dra. Maria Bernadete A. Varesche, pela orientação.

A Tininha e Lorena, pela disposição em repassar suas experiências com o LAS e também pela imensa ajuda no decorrer de todo o trabalho.

À Katita, que sempre esteve disposta a ajudar com a maior boa vontade do mundo com a Biomol.

À Dani, que tem o dom de zelar pelas relações sociais no ambiente de trabalho, pela ajuda nas microscopias.

Ao Prof. Marcelo Zaiat, pelas críticas e sugestões bem colocadas durantes os exames de qualificação.

A Janja, Elô e Profa. Beth, por toda a atenção e explicações dadas nos vários momentos de "dúvidas de bancada".

Ao estagiário Eduardo, pelo auxílio com o monitoramento do reator.

Ao Prof. Roberto Alves de Oliveira da UNESP de Jaboticabal, pelo fornecimento do inóculo.

Às secretárias Sá e Pavi, por sempre terem resolvido os problemas burocráticos insolúveis.

Ao Cnpq, pela bolsa de estudo concedida.

À Lissa, que entrou em minha vida de maneira tão arrebatadora, por todo carinho, atenção e incentivo.

Aos amigos do LPB: Dani, Márcia, Léo, Mércia, Sandra, Gunther, Ono, Carol, Bruna, Dago, Maurício, Arnaldo, Júlia, Madá, Monique, Renata, Lara, Isabel, Amanda, pelas valiosas conversas no café e na bancada.

Aos amigos da turma do mestrado: Dibeatles, Curió, Neyzão, Jorge, Pescoço, Patrick, Tati cabeção, Tati Catarina, Felipe, Flávia, Gaúcho, Baiana, Camila Tchu, Gustavo, Paraíba, Guma, pelos bons momentos vividos em São Carlos.

Aos amigos da Bio: Rodrigo, Cabeção, Fernando, Moita, Karina, Lil, Marina, Mari, Cassi, Ivãzinho, Jorge, Maria, pelo companheirismo e pela boa influência que as amizades causam. 
A meus pais, Joel e Malú, por terem me oferecido apoio incondicional em todos os momentos de minha vida.

A meus irmãos, Thi e Carol, por nossas infâncias compartilhadas.

A toda minha grande família, que nunca entendeu o título desse trabalho, mas que sempre me incentivou e esteve aguardando ansiosamente a realização de mais essa etapa da minha vida. 
"No es el encuentro programado, el simposio, la conferencia o la cita lo que genera cultura: estas sólo la difunden; lo que la genera es el encuentro fortuito, la conversación en la calle, la visita espontánea al taller, el paseo inesperado donde se encuentra un amigo y se le comunican las preocupaciones creatives del día, la conversación desinteresada. Por definición, la creatividad no se puede programar: surge oscuramente, a su aire, azarosa, incontrolada, inspirada que no forzada. Por lo mismo, es en un ambiente informal y no programado donde se dan los intercambios e impulsos a la creatividad. Por encuentro programado no puede salir nada nuevo; el brain storming es um método de publicitarios, no de creadores."

Luis Racionero 



\section{RESUMO}

PINHEIRO FILHO, J. D. Degradação de alquilbenzeno linear sulfonado em reator anaeróbio operado em bateladas seqüenciais com biomassa imobilizada em carvão vegetal. Dissertação (Mestrado) - Escola de Engenharia de São Carlos, Universidade de São Paulo, São Carlos, 2008.

Neste trabalho foi utilizado reator anaeróbio operado em bateladas seqüenciais com biomassa imobilizada para avaliação da remoção e degradação de alquilbenzeno sulfonado linear (LAS). O volume útil do sistema foi de 2,6 L, sendo a temperatura mantida constante a $30 \pm 1^{\circ} \mathrm{C}$. O inóculo, lodo proveniente de reator UASB utilizado no tratamento de resíduos de suinocultura, foi imobilizado em partículas de carvão vegetal. A alimentação consistiu de substrato sintético acrescido de LAS. A operação foi dividida em quatro etapas: (1) substrato sintético sem LAS, (2) substrato sintético acrescido de $12 \pm 3 \mathrm{mg} / \mathrm{L}$ de LAS, (3) substrato sintético acrescido de $32 \pm 5 \mathrm{mg} / \mathrm{L}$ de LAS e (4) substrato sintético sem sacarose acrescido de $10 \pm 2 \mathrm{mg} / \mathrm{L}$ de LAS. O reator, operado durante 256 dias, mostrou estabilidade operacional sob baixas concentrações de LAS (12 \pm 3 e $10 \pm 2 \mathrm{mg} / \mathrm{L}$ ). A elevação da concentração de LAS a $32 \pm 5 \mathrm{mg} / \mathrm{L}$ influenciou negativamente o processo de digestão anaeróbia. Nessa concentração, atingiu-se a mínima eficiência de remoção média de DQO (53\% \pm 12 p.p.) e houve consumo de alcalinidade (valor mínimo de $241 \mathrm{mgCaCO}_{3} / \mathrm{L}$ ) associado ao acúmulo de ácidos voláteis (concentração máxima de $97 \mathrm{mgHAc} / \mathrm{L}$ ). Sob essas condições, atribui-se o inadequado desempenho do reator possivelmente ao comprometimento de suas condições hidrodinâmicas, que podem ter sido afetadas pela produção excessiva de exopolímeros. Com a diminuição da concentração de LAS a $10 \pm 2 \mathrm{mg} / \mathrm{L}$ o sistema mostrou recuperação. Nessa última fase foi verificada remoção de $70 \% \pm 5$ p.p. de DQO, para 61 dias de operação. O balanço de massa do LAS indicou remoção de $18 \%$, enquanto que sua degradação biológica atingiu $16 \%$. Concluiu-se que configuração testada, com biomassa imobilizada, não foi considerada adequada ao tratamento de águas residuárias contendo LAS. As análises microscópicas revelaram ampla variedade morfológica e não se constatou diferenças significativas quanto as morfologias encontradas no inóculo e durante as fases de operação. Por meio de técnicas de Biologia Molecular (PCR/DGGE), constatou-se que o meio suporte foi seletivo para o Domínio Bacteria.

Palavras-chave: adsorção, ASBBR, carvão vegetal, LAS, surfactante 



\section{ABSTRACT}

PINHEIRO FILHO, J. D. Biodegradation of linear alkylbenzene sulfonate in anaerobic sequencing biofilm batch reactor with biomass immobilization in charcoal. Dissertation (Master) - Escola de Engenharia de São Carlos, Universidade de São Paulo, São Carlos, 2008.

This work used an anaerobic sequencing biofilm batch reactor aiming the removal and degradation of the linear alkylbenzene sulfonate (LAS). Biomass from an UASB reactor treating suine wastewater was immobilized in charcoal fragments. The reactor was fed with synthetic substrate with addition of LAS. Feeding happened in four stages: (1) synthetic substrate without LAS, (2) synthetic substrate with LAS at $12 \pm 3 \mathrm{mg} / \mathrm{L}$, (3) synthetic substrate with LAS at $32 \pm 5 \mathrm{mg} / \mathrm{L}$ and (4) synthetic substrate with LAS at $10 \pm 2 \mathrm{mg} / \mathrm{L}$. The reactor, which was monitored for 256 days, has shown good stability under low LAS concentrations $(12 \pm 3$ e $10 \pm 2 \mathrm{mg} / \mathrm{L})$. Rising in LAS concentration to $32 \pm 5 \mathrm{mg} / \mathrm{L}$ have negatively influenced anaerobic digestion. At this concentration, the lowest organic matter removal efficiency $(55 \% \pm 12$ p.p.) was attained and alkalinity consumption took place (lowest value of $241 \mathrm{mgCaCO}_{3} / \mathrm{L}$ ) associated with amassing of volatile acids (peak value of $97 \mathrm{mgHAc} / \mathrm{L}$ ). Under these conditions, the ill-suited performance shown by the reactor is assumed to be caused by the compromising of the reactor's hydrodynamics properties, which could have been affected by the observed extracellular polymers overproduction. The reactor showed good performance recovery when the LAS concentration was lowered to $10 \pm 2 \mathrm{mg} / \mathrm{L}$. The last stage reached $70 \% \pm 5$ p.p. of organic matter removal efficiency within 61 days. LAS mass balance indicated that $18 \%$ of the mass affluent to the reactor were removed by biodegradation and adsorption, while $16 \%$ were biologically degraded. Upon the obtained results, it was concluded that the proposed configuration is not suited in treating wastewaters containing LAS. Microscopic investigations have revealed notable microbial morphological variety and it could not been distinguished significative differences between inoculum's and reactor's samples microbial morphologies. Through Molecular Biology techniques (PCR/DGGE), it was observed that the support material has allowed growth of some bacterial populations that were not found in the inoculum.

Keywords: adsorption, ASBBR, charcoal, LAS, surfactant 



\section{LISTA DE FIGURAS}

Figura 3.1 Estrutura do alquilbenzeno linear sulfonado 5

Figura 4.1 Fluxograma experimental geral 15

Figura 4.2 Esquema do reator anaeróbio operado em bateladas seqüenciais 16

Figura 5.1 Ajuste médio do modelo de Boltzmann aos valores normalizados de pH do sistema a $200 \mathrm{rpm}$

Figura 5.2 Ajuste médio do modelo de Boltzmann aos valores normalizados de $\mathrm{pH}$ do sistema a $300 \mathrm{rpm}$

Figura 5.3 Ajuste médio do modelo de Boltzmann aos valores normalizados de $\mathrm{pH}$ do sistema a $400 \mathrm{rpm}$

Figura 5.4 Ajuste médio do modelo de Boltzmann aos valores normalizados de $\mathrm{pH}$ do sistema a $500 \mathrm{rpm}$

Figura 5.5 Ajuste médio do modelo de Boltzmann aos valores normalizados de $\mathrm{pH}$ do sistema a $600 \mathrm{rpm}$

Figura 5.6 Ajuste médio do modelo de Boltzmann aos valores normalizados de $\mathrm{pH}$ do sistema a $700 \mathrm{rpm}$

Figura 5.7 Tempo de mistura em função da freqüência de agitação nos ensaios hidrodinâmicos

Figura 5.8 Adsorção de LAS durante o primeiro ensaio de adsorção (27 mg/L) no meio suporte em função do tempo de contato

Figura 5.9 Adsorção de LAS durante o segundo ensaio de adsorção (57 mg/L) no meio suporte em função do tempo de contato .....

Figura 5.10 Evolução temporal da massa de LAS acumulada no afluente (•) e efluente (o) e eficiência de remoção de LAS (

Figura 5.11 pH médio afluente ( $\square$ ) e efluente ( $\square$ ) nas fases de operação 40 
Figura 5.12 Variação temporal da DQO afluente ( $\square$ ) e efluente (ロ) do reator ...... 41

Figura 5.13 DQO média afluente ( $\square$ ) e efluente (ロ) em cada etapa de operação. 42

Figura 5.14 Variação temporal da eficiência de remoção de DQO no reator. 43

Figura 5.15 Variação temporal da alcalinidade a bicarbonato no reator. 45

Figura 5.16 Variação temporal da alcalinidade parcial afluente (०) e efluente $(\bullet)$ e alcalinidade total afluente $(\square)$ e efluente $(\square)$ do reator .45

Figura 5.17 Variação temporal de ácidos voláteis totais no reator. 46

Figura 5.18 Microscopia de contraste de fase de morfologias microbianas presentes no inóculo: (a) Methanosaeta sp. e bacilos retos e curvos; (b) Methanosarcina sp.

Figura 5.19 Microscopia de contraste de fase de morfologias microbianas presentes no reator durante a primeira etapa de operação: (a) bacilos, (b) Methanosarcina $\mathrm{sp}$

Figura 5.20 Microscopia de contraste de fase de morfologias microbianas presentes no reator durante a segunda fase de operação: (a) bacilos curvos, (b) Methanosaeta sp.

Figura 5.21 Microscopia de contraste de fase de morfologias presentes no reator durante a terceira fase de operação: (a) Methanosaeta sp. e Methanosarcina sp., (b) bacilos 49

Figura 5.22 Microscopia de contraste de fase de morfologias presentes no reator durante a quarta fase de operação: (a) bacilos, (b) Methanosarcina sp....... 49

Figura 5.23 Perfil das bandas de DGGE para o Domínio Bacteria de amostras do (a) inóculo e (b) carvão vegetal ao final de 256 dias de operação 


\section{LISTA DE TABELAS}

Tabela 4.1 Caracterização do material suporte.

Tabela 4.2 Composição do substrato sintético 18

Tabela 4.3 Composição da solução de sais 19

Tabela 4.4 Fases de operação do reator 20

Tabela 4.5 Análises de monitoramento do reator .21

Tabela 4.6 Condições cromatográficas para quantificação do LAS. 21

Tabela 4.7 Condições utilizadas na reação em cadeia da polimerase 25

Tabela 4.8 Primers filogenéticos utilizados para o Domínio Bacteria .25

Tabela 5.1 Valores da Constante de tempo $(\tau)$, do Centro da Sigmóide $\left(\mathrm{t}_{0}\right)$ e do Tempo de Mistura $\left(\mathrm{t}_{\mathrm{M}}\right)$, calculados pelo modelo de Boltzmann para as velocidades de agitação aplicadas ao sistema nos ensaios hidrodinâmicos ........30

Tabela 5.2 Balanço de massa do LAS para o primeiro ensaio de adsorção (27 mg/L)........33

Tabela 5.3 Balanço de massa do LAS para o segundo ensaio de adsorção (57 mg/L) ........33

Tabela 5.4 Balanço de massa do LAS 35

Tabela 5.5 Pesquisas do Laboratório de Processos Biológicos da EESC/USP visando a degradação do LAS

Tabela 5.6 Valores de pH máximos e mínimos observados durante o monitoramento 39

Tabela 5.7 Caracterização morfológica microbiana do reator. .50 



\section{LISTA DE ABREVIATURAS}

AB Alcalinidade a bicarbonato

ASBBR Reator anaeróbio operado em bateladas seqüenciais com biomassa imobilizada (anaerobic sequencing biofilm batch reactor)

ASBR Reator anaeróbio operado em bateladas seqüenciais (anaerobic sequencing batch reactor)

AVT Ácidos voláteis totais

BTEX Benzeno, toluene, etilbenzeno e xilenos

CSTR Reator contínuo tipo tanque agitado (continuous stirred tank reactor)

DGGE Eletroforese em gel de gradiente desnaturante (denaturing gradient gel electrophoresis)

DNA Ácido desoxiribonucléico

DQO Demanda química de oxigênio

ETE Estação de tratamento de esgoto

HPLC Cromatografia líquida de alta eficiência (high performance liquid chromatografy)

LAB Alquilbenxeno linear (linear alkylbenzene)

LAS Aquilbenzeno linear sulfonado (linear alkylbenzene sulfonate)

LPB Laboratório de Processos Biológicos

L/D Relação comprimento/diâmetro (length/diameter)

PCR Reação em cadeia da Polimerase

RAHLF reator anaeróbio horizontal de leito fixo

SPC Sulfofenil carboxilato

TDH Tempo de detenção hidráulica 
UASB Reator anaeróbio de fluxo ascendente e manta de lodo (upflow anaerobic sludge blanket reactor)

UNESP Universidade Estadual Paulista "Júlio de Mesquita Filho"

USP Universidade de São Paulo 


\section{LISTA DE SÍMBOLOS}

HAc ácido acético

p. p. ponto percentual

$\mathrm{t}_{0} \quad$ centro da curva sigmóide

$\mathrm{t}_{\mathrm{M}} \quad$ tempo de mistura

$\sigma \quad$ desvio padrão

$\tau \quad$ constante de tempo 



\section{SUMÁRIO}

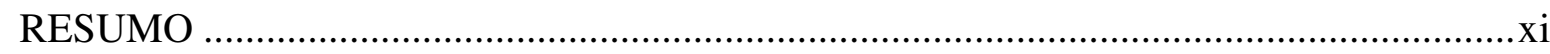

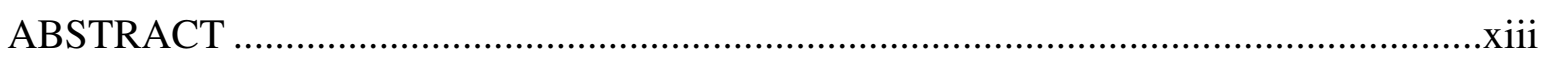

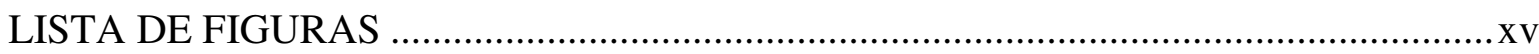

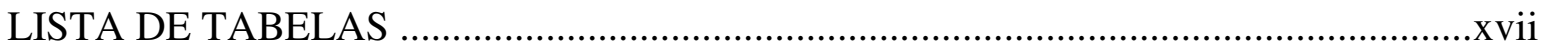

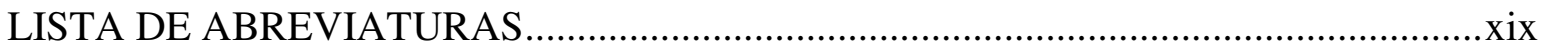

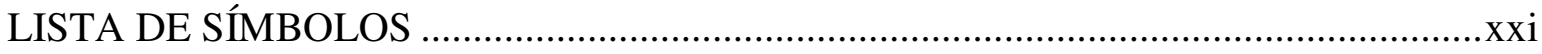

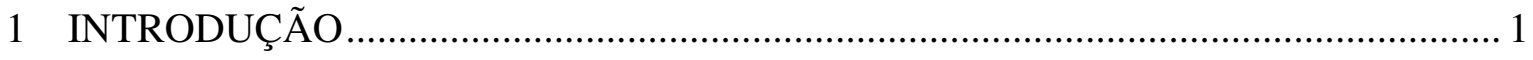

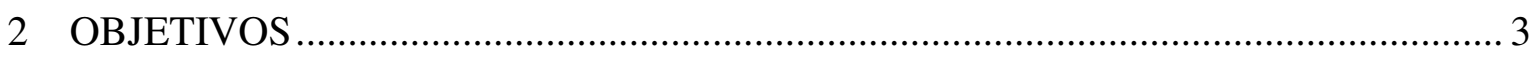

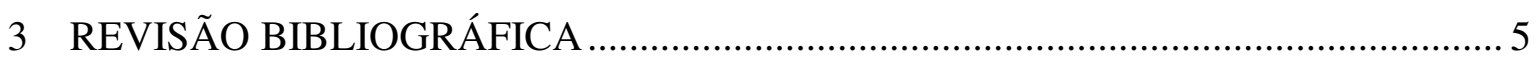

3.1 Caracterização do Alquilbenzeno Linear Sulfonado ................................................ 5

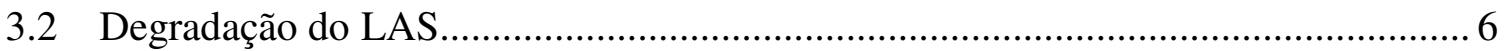

3.3 Microrganismos envolvidos na degradação de LAS ................................................ 9

3.4 Reator Anaeróbio operado em Bateladas Seqüenciais com Biomassa Imobilizada 11

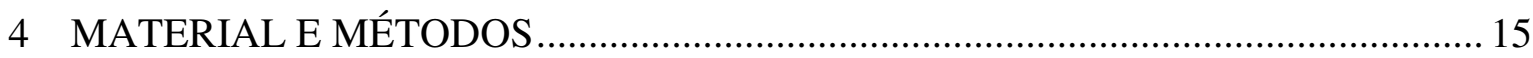

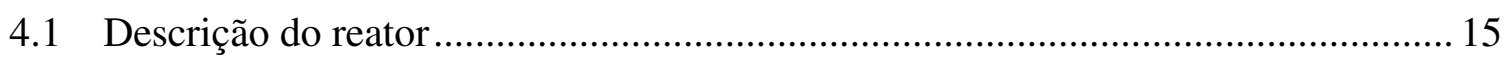

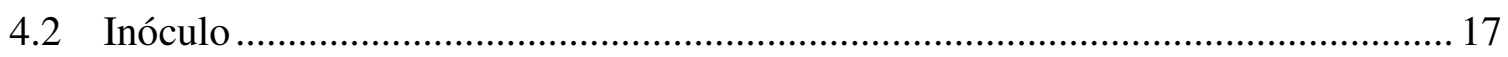

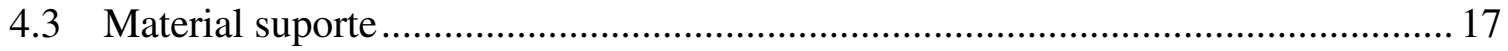

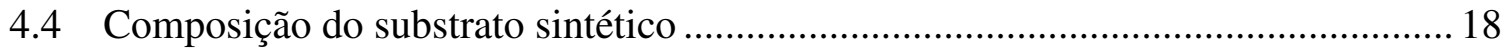

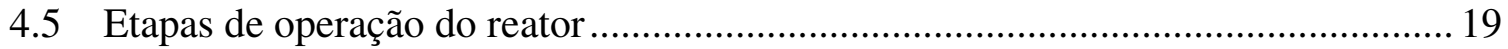

4.6 Análises físico-químicas e cromatográficas .......................................................... 20

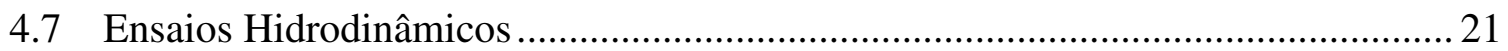

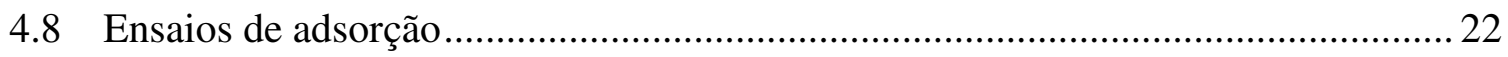

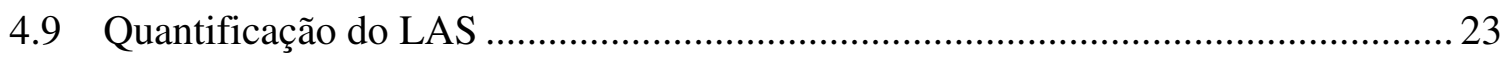

4.9.1 Extração do LAS adsorvido no material suporte............................................. 23

4.9.2 Purificação da Amostra contendo LAS em Coluna de Troca Iônica............... 24

4.9.3 Concentração do LAS em Coluna de Fase Sólida............................................ 24

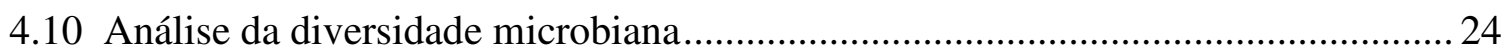

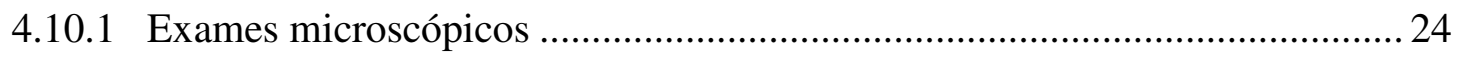

4.10.2 Técnicas de Biologia Molecular ................................................................. 25

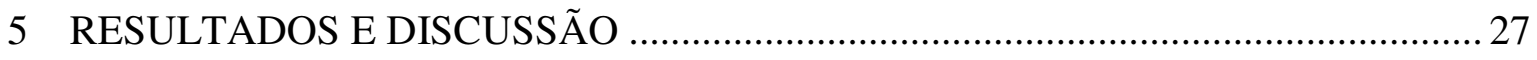

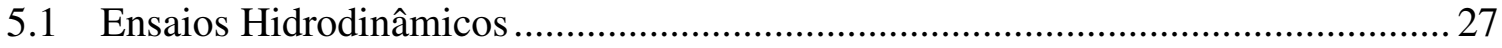

5.2 Adsorção de LAS no material suporte.................................................................. 31

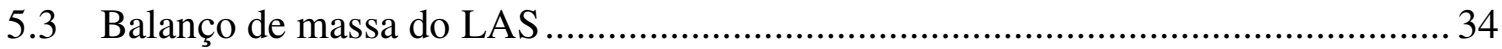




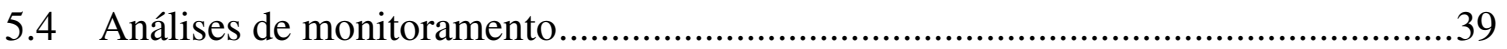

5.4.1 Potencial Hidrogeniônico..................................................................................

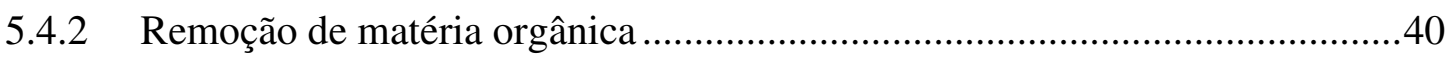

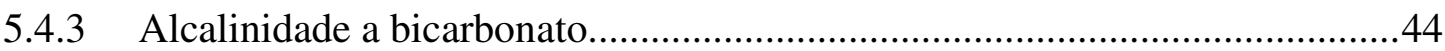

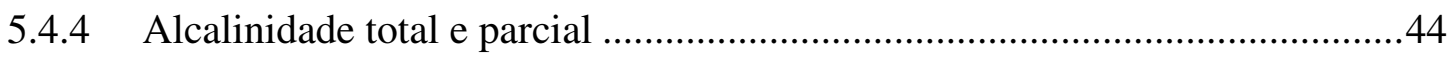

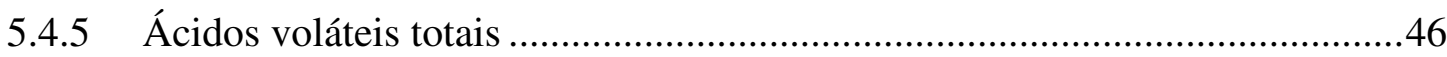

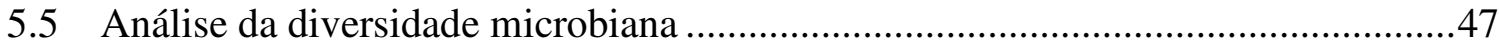

5.5.1 Caracterização do inóculo ...........................................................................

5.5.2 Caracterização das amostras do reator ..............................................................48

5.5.3 Técnicas de Biologia Molecular .......................................................................50

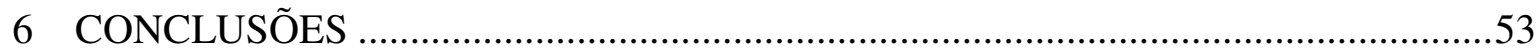

7 SUGESTÕES PARA TRABALHOS FUTUROS …....................................................55

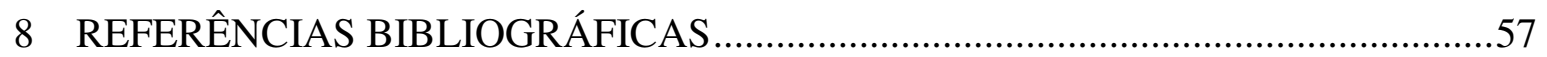




\section{INTRODUÇÃO}

A crescente preocupação com a questão ambiental, particularmente em relação à poluição das águas, tem criado demanda pelo desenvolvimento de novas tecnologias que visam remoção de compostos orgânicos provenientes dos efluentes industriais e domésticos. Tal preocupação surge, dentre outras razões, da necessidade de se degradar ou remover os compostos sintéticos produzidos pelo homem.

Dentre esses compostos de interesse ambiental encontra-se o alquilbenzeno linear sulfonado (LAS). O LAS é um surfactante e representa um dos principais constituintes do detergente comercial. Depois do sabão, o LAS é o surfactante mais produzido e consumido em todo o mundo. Seu consumo em 2000 foi estimado em 2,5 milhões de toneladas (SANZ et al., 2003). Esta elevada demanda estimulou extensivas investigações, tanto em âmbito industrial quanto acadêmico, o que propiciou a produção de farta literatura a respeito de seus destinos e efeitos no ambiente (OLIVEIRA, 2006). Contudo, o LAS ainda representa uma importante fonte poluidora dos ecossistemas naturais.

Devido à porção hidrofílica da molécula, considerável porção do LAS adsorve ao lodo gerado durante o processo de tratamento aeróbio, por exemplo. Freqüentemente, o lodo gerado passa pelo processo de digestão anaeróbia como técnica de estabilização antes de sua disposição final. Apesar de a degradação aeróbia do LAS já ter sido bem estudada, sua degradação sob condições anaeróbias ainda carece de investigação mais aprofundada.

O LAS é considerado recalcitrante aos processos anaeróbios. Contudo, alguns trabalhos já foram realizados (GAVALA \& AHRING, 2002; SANZ et al., 2003; MOGENSEN et al., 2003; LÖBNER et al., 2005; DUARTE, 2006 e OLIVEIRA, 2006) e mostraram a viabilidade de se degradar esse surfactante sob condições anaeróbias. 
Surge assim, a importância de se continuar estudando a degradação anaeróbia desse surfactante, buscando configurações alternativas de sistemas de tratamento.

Recentemente, propostas alternativas têm sido investigadas pelo Laboratório de Processos Biológicos (LPB) da Escola de Engenharia de São Carlos (EESC-USP). Essas configurações utilizam reatores em escala de bancada e têm enfatizado a importância da aplicação dos processos anaeróbios na degradação de compostos tóxicos.

Assim, o presente trabalho baseou-se na experiência adquirida de trabalhos anteriores (DUARTE, 2006; OLIVEIRA, 2006) e procurou dar continuidade à busca de alternativas para a biodegradação anaeróbia de LAS. Para tanto, foi utilizado um reator anaeróbio operado em bateladas seqüenciais com biomassa imobilizada (ASBBR). A configuração proposta, ao utilizar biomassa imobilizada, pode constituir alternativa atrativa para a degradação de xenobióticos, uma vez que essa configuração tem obtido resultados promissores (PINHO et al., 2005; MIQUELETO, 2006; SARTI \& FORESTI, 2007; FRIEDL, 2008). 


\section{OBJETIVOS}

O objetivo geral dessa pesquisa foi avaliar a remoção e biodegradação do LAS em ASBBR com biomassa imobilizada em carvão vegetal.

Os objetivos específicos foram:

$\checkmark$ Avaliar o potencial adsortivo do LAS em relação ao meio suporte por meio de ensaios de adsorção;

$\checkmark$ Determinar a frequiência de agitação a ser utilizada durante toda a operação do reator, utilizando-se ensaios hidrodinâmicos;

Quantificar o LAS adsorvido no meio suporte e biofilme nas diferentes fases de operação do reator;

$\checkmark$ Analisar o desempenho global do reator pelo monitoramento de parâmetros físicoquímicos;

Avaliar a comunidade bacteriana por meio de exames microscópicos e técnicas de Biologia Molecular (PCR/DGGE). 



\section{REVISÃO BIBLIOGRÁFICA}

\subsection{Caracterização do Alquilbenzeno Linear Sulfonado (LAS)}

A molécula de LAS (Figura 3.1) é constituída por uma porção hidrofóbica, representada por uma cadeia alquílica; e uma hidrofílica, constituída por um anel aromático sulfonado. A cadeia alquílica pode variar em tamanho (10 a 14 átomos de carbono), o que caracteriza a existência de diferentes homólogos desse composto. O anel aromático pode ligar-se à cadeia alquílica em qualquer posição (exceto nos carbonos terminais), o que caracteriza a existência de diferentes isômeros de LAS. Assim, o termo LAS abrange todo o conjunto de isômeros e homólogos do alquilbenzeno linear sulfonado. O LAS comercial é constituído de uma mistura desses isômeros e homólogos em diferentes concentrações.

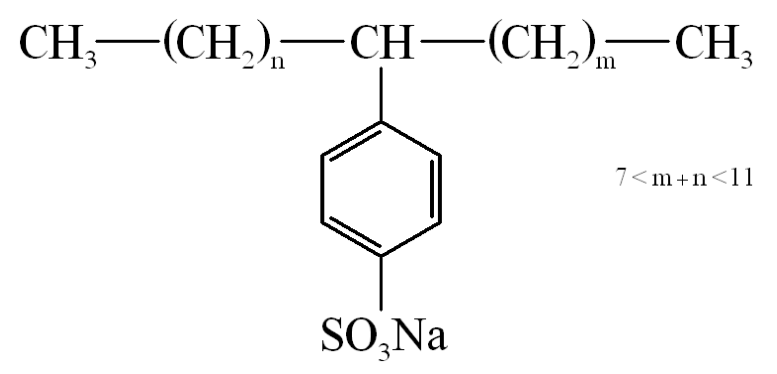

Figura 3.1 Estrutura do alquilbenzeno linear sulfonado

A síntese do LAS é realizada por meio da reação entre o alquilbenzeno linear (LAB) e o ácido sulfúrico seguida de neutralização com hidróxido de sódio (FERRER et al., 2002).

O LAS representa mais de $40 \%$ de todo surfactante utilizado no mundo, assim, atenção especial deve ser dada a sua ocorrência e destino no ambiente. A degradação aeróbia do LAS já foi tema de diversos trabalhos e eficiências de degradação de 97-99\% já foram relatadas (SCOTT \& JONES, 2000). Contudo, sob essas condições de tratamento pode-se ter eficiência reduzida, quando são utilizadas concentrações de LAS entre 20 a 50 mg/L. Além disso, concentrações maiores que essas podem inibir totalmente o processo de tratamento aeróbio (PATTERSON et al., 2001). 


\subsection{Degradação do LAS}

Em estações de tratamento, o LAS é parcialmente biodegradado. Considerável porção fica adsorvida ao lodo, que via de regra, tem a disposição no solo como destino final (geralmente, em aterros). Cerca de 10 a 20\% do LAS presente no esgoto estão associados aos sólidos suspensos e não são degradados nos sistemas aeróbios de tratamento (BERNA et al., 2000).

Em relação à sua toxicidade, tem sido relatado que mesmo a $0,2 \mathrm{mg} / \mathrm{L}$ o LAS pode ter efeito tóxico crônico sobre a biota aquática (HOFER et al. 1995). Berna et al. (2000) relatam que concentrações de LAS entre 5 a $17 \mathrm{mg} / \mathrm{kg}$ encontradas em sedimento de rios não mostraram efeito inibitório sobre o metabolismo bacteriano.

Considerando-se a microbiota, alguns problemas associados à presença de surfactantes se devem à formação de espuma, inibidora dos processos autodepurativos e que pode disseminar microrganismos patogênicos, metais pesados e impurezas. Neste caso, podem diminuir a dissolução de oxigênio atmosférico na água e afetar o transporte dessa molécula através das membranas celulares dos microrganismos. Também, influenciam negativamente a homeostase microbiana, já que podem causar a desnaturação de enzimas e o rompimento das membranas celulares, dificultando a excreção de metabólitos tóxicos (CSERHÁTI et al., 2002).

Na degradação aeróbia do LAS, os produtos intermediários mais conhecidos são os sulfofenis carboxilatos (SPC). Contudo, esses intermediários também foram encontrados em sedimentos marinhos anaeróbios da Baia de Cádiz, na Espanha (LEÓN et al., 2000). Os intermediários da degradação anaeróbia em condições mesofílicas ainda não foram totalmente identificados. Em condições termofílicas, foi constatado no efluente de UASB utilizado no tratamento de LAS (2 mg/L.dia) com tempo de detenção hidráulica (TDH) de 12 horas a presença de ácido benzenosulfônico, ácido sulfônico p-tolueno, 1-fenildodecano, ácido 2- 
fenilbutírico, 2-butilbenzeno, 1-fenilhexano e ácido acético (MOGENSEN \& AHRING, 2002).

Nos sistemas aeróbios, a mineralização do LAS envolve as seguintes etapas: (1) clivagem da cadeia alquílica, (2) degradação do grupo sulfonado e (3) rompimento do anel benzênico (PERALES et al., 1999). Mais especificamente, segundo Schöberl (1989), as vias para a degradação aeróbia de LAS compreendem as seguintes etapas: (1) conversão oxidativa de um ou dois grupos metila da cadeia alquílica a um grupo carboxila ( $\omega$-/ $\beta$-oxidação); (2) oxidação da cadeia alquílica ( $\beta$-oxidação); (3) oxidação do anel aromático e (4) rompimento da ligação C-S, liberando sulfato (dessulfonação). A etapa mais difícil é a ruptura da ligação do radical alquila com o anel aromático sulfonado (CAVALLI et al., 1996).

Schöberl (1989) distingue duas etapas na degradação biológica do LAS: a biodegradação primária e final. Na primeira, ocorre alteração na estrutura do composto de maneira que a molécula perde suas propriedades surfactantes, enquanto que por biodegradação final entende-se a completa mineralização do composto, isto é, sua conversão a gás carbônico, água e sais minerais.

Em relação à degradação anaeróbia, Shcherbakova et al. (1999) propuseram um mecanismo hipotético de clivagem do anel aromático. Neste caso, os autores concluíram que ocorre a formação de compostos aromáticos e cíclicos que podem inibir alguns estágios da metanogênese. Mesmo assim, deve-se ressaltar que as etapas da degradação anaeróbia do LAS ainda não estão claramente definidas, assim como as informações sobre a influência dos compostos intermediários gerados no processo sobre o crescimento dos microrganismos.

Surfactantes em geral são prejudiciais (GAVALA \& AHRING, 2002) e considerados inibidores severos (FEITKENHAUER \& MEYER, 2002) da digestão anaeróbia. Segundo Gavala \& Ahring (2002), a recalcitrância do LAS na digestão anaeróbia pode explicar a distribuição desse composto no ambiente já que o lodo anaeróbio gerado em ETEs, com LAS adsorvido, pode ter disposição final em aterros e terras cultiváveis. 
Angelidaki et al. (2000) e Mogensen et al. (2003) sugeriram que os insucessos obtidos em trabalhos anteriores se deveram possivelmente à falta de biodisponibilidade de LAS. Angelidaki et al. (2000) relataram a degradação anaeróbia de LAS em dois reatores (CSTR) operados com TDH de 15 dias. Os autores avaliaram o efeito da concentração de LAS afluente (102 a 268 mg/L) e de sólidos totais (11 e 20 g/L) sobre a degradação do surfactante, sendo constatadas eficiências de degradação entre 14 e $25 \%$.

Mongensen et al. (2003) avaliaram CSTR operado de maneira semi-contínua com concentração de sólidos totais inicial de 20 g/L e LAS a 100 mg/L. Os autores observaram que a degradação de LAS aumentou de $20 \%$ para $28 \%$ quando a concentração de sólidos foi reduzida pela metade. Corroborando com os relatos de Angelidaki et al. (2000), concluiu-se que a velocidade de remoção de LAS esteve correlacionada à biodisponibilidade desse composto e quanto menor a concentração de sólidos, maior a degradação de LAS. Assim, a presença de LAS adsorvido ao lodo pode ser determinante na eficiência do processo. Daí a importância de se considerar o processo de adsorção em estudos com LAS.

Alguns trabalhos desenvolvidos no Laboratório de Processos Biológicos da Escola de Engenharia de São Carlos buscaram avaliar a degradação de LAS em reatores anaeróbios. Duarte (2006) utilizou dois reatores anaeróbios horizontais de leito fixo (RAHLF) preenchidos com espuma de poliuretano visando a degradação desse surfactante. Um reator foi inoculado com lodo de reator UASB usado no tratamento de esgoto sanitário e o outro com lodo proveniente de reator UASB utilizado no tratamento de dejetos de suinocultura.

Pelos resultados obtidos verificou-se que aproximadamente $35 \%$ de todo LAS adicionado aos reatores foi removido por degradação biológica para concentração afluente de 14 mg/L, após 313 dias de operação e tempo de detenção hidráulica (TDH) de 12 horas. No entanto, a autora relatou formação excessiva de exopolímeros, o que acabou por dificultar o escoamento hidrodinâmico do sistema. A clonagem de fragmentos do RNAr 16S de amostras 
obtidas da biomassa aderida ao meio suporte revelou que $81 \%$ dos clones obtidos pertenciam à Classe Clostridia.

Miqueleto (2006) afirma que a produção de exopolímeros em sistemas anaeróbios está relacionada a diversos fatores, tais como, fonte de carbono utilizada, altas relações carbono/nitrogênio, condições microaerofílicas.

Outro trabalho visando a remoção de LAS foi realizado por Oliveira (2006). Esta autora avaliou diferentes materiais (argila expandida, carvão vegetal e espuma de poliuretano) quando utilizados como meio suporte em RAHLF. Foram operados dois reatores, ambos com TDH de 12 horas e volume de 2 litros. Um reator foi preenchido com carvão vegetal, enquanto no outro foi utilizado leito composto de espuma de poliuretano e argila expandida na proporção 80/20 (v/v). Os dois reatores comportaram-se de maneira semelhante em relação à degradação de LAS, apresentando aproximadamente $27 \%$ de remoção biológica, para concentração afluente média de $14 \mathrm{mg} / \mathrm{L}$. A autora concluiu que o reator preenchido com carvão vegetal foi mais adequado para a degradação do LAS, já que o surfactante apresentou menor adsorção ao meio suporte. Houve ampla diversidade microbiana e os meios suportes foram capazes de selecionar populações. Após a retirada dos substratos orgânicos da alimentação, a remoção em ambos os reatores passou de aproximadamente $30 \%$ para $70 \%$.

\subsection{Microrganismos envolvidos na degradação de LAS}

É sabido que várias espécies de microrganismos interagem sinergicamente na degradação do LAS. Jimenez et al. (1991) estudaram o consórcio microbiano constituído por três espécies de Pseudomonas sp. e uma de Aeromonas sp. em quimiostato Bioflow. O LAS foi adicionado a $10 \mathrm{mg} / \mathrm{L}$ como única fonte de carbono e enxofre. O consórcio estudado foi capaz de degradar mais de $25 \%$ do LAS adicionado.

Culturas de bactérias puras ou mistas em condições fermentativas vêm sendo empregadas com a finalidade de melhorar a decomposição de surfactantes (CSERHÁTI et al., 2002). Segundo Goudar et al. (1999), a degradação de surfactantes aniônicos torna-se mais 
rápida com utilização de culturas mistas do que culturas isoladas. De acordo com Cook \& Hrsak (2000), o uso de culturas puras para mineralização do LAS não foi bem sucedida. Sob tais condições, provavelmente, não foram sintetizadas todas as enzimas necessárias para promover a ruptura da molécula. Os autores concluíram que a degradação total ocorre somente pela cooperação de várias populações microbianas atuando em sinergismo.

Denger \& Cook (1999) usaram culturas enriquecidas com LAS em condições anaeróbias em meio contendo glicose a $10 \mathrm{mmol} / \mathrm{L}$. Essas culturas utilizaram o surfactante como fonte de enxofre para o crescimento microbiano. Uma das linhagens isoladas foi denominada RZLAS, que por meio de seqüenciamento de fragmentos do RNAr 16S, foi classificada como pertencendo à subdivisão $\gamma$ de Proteobacteria. Os autores obtiveram valores de maior similaridade para Aeromonas $(88,2-90,1 \%)$ e Shewanella $(87,0-88,1 \%)$.

Nesse sentido, Khleifat (2006) relatou a ocorrência de biodegradação de LAS por cocultura anaeróbia facultativa constituída por Pantoea agglomerans e Serratia odorifera 2. Verificou-se que a degradação ocorreu mais eficientemente quando as duas espécies mantiveram-se em consórcio do que quando mantidas separadamente. Os experimentos foram realizados em batelada em frascos de $250 \mathrm{~mL}$ com LAS a $200 \mathrm{mg} / \mathrm{L}$ e duração de 120 horas. Em co-cultura as espécies degradaram $70 \%$ do LAS. Isoladamente $P$. aglomerans e $S$. odorifera degradaram $30 \%$ e $25 \%$, respectivamente. Esses resultados indicaram possível cooperação catabólica na degradação do LAS.

Almendariz et al. (2001) avaliaram a degradação de LAS a 20 e $50 \mathrm{mg} / \mathrm{L}$ em reatores UASB acidogênico e metanogênico dispostos em série. Os autores relataram eficiência de remoção de LAS de $41 \%$. Essa remoção se deu somente no compartimento acidogênico. Esses resultados são concordantes com a argumentação de Speece (1996), que defende que as bactérias acidogênicas crescem mais rapidamente e são menos sensíveis a variações ambientais quando comparadas com as metanogênicas acetoclásticas. O LAS foi inibitório ao 
reator metanogênico, contudo, o sistema voltava a apresentar remoção de matéria orgânica quando o LAS era excluído da alimentação. Assim, essa inibição além de apresentar-se tanto parcial quanto total, foi reversível.

Gavala \& Ahring (2002) testaram a inibição do LAS em lodo anaeróbio de um CSTR e culturas enriquecidas previamente em meio contendo acetato e propionato. $\mathrm{O}$ experimento foi realizado em frascos de antibiótico de $60 \mathrm{~mL}$. No meio de cultura dos ensaios com lodo anaeróbio, acetato ou propionato foram adicionados como fonte de carbono a $0,5 \mathrm{~g} / \mathrm{L}$, enquanto que nos frascos das culturas enriquecidas esses compostos foram adicionados a 1,0 g/L. Os autores observaram que as bactérias utilizadoras de propionato foram mais sensíveis, para a mesma concentração de LAS, do que as utilizadoras de acetato.

Sanz et al. (2003) compararam o desempenho de dois reatores UASB de 5,4 L para a remoção de LAS. Um reator (R1) foi alimentado com substrato sintético acrescido de LAS a 5 $\mathrm{mg} / \mathrm{L}$ e o outro (R2) somente com solução isotônica de LAS, também a $5 \mathrm{mg} / \mathrm{L}$. Os autores constataram que a presença de fontes orgânicas de carbono que não o LAS, diminuiu a biodegradação do surfactante, que apresentou média de $64 \%$. No reator 2, essa eficiência foi de $85 \%$. Ainda, os autores relataram que o LAS não causou nenhum efeito sobre a biomassa e a atividade metanogênica foi estável em todo o experimento.

Entre as diversas configurações de reatores anaeróbios empregados no tratamento de águas residuárias, a mais utilizada na degradação de alquilbenzeno linear sulfonado foi o UASB, mas outras configurações vêm sendo testadas. Entre elas, inclui-se o reator anaeróbio operado em bateladas seqüenciais (ASBR).

\subsection{Reator Anaeróbio operado em Bateladas Seqüenciais com Biomassa Imobilizada}

Nas últimas décadas, o reator operado em bateladas seqüenciais tem recebido maior atenção da comunidade científica devido, especialmente, a seus aspectos práticos de operação e automação para o tratamento de águas residuárias em geral. Tal interesse contribui para 
difusão dessa tecnologia, que hoje pode ser aplicada a maior diversidade de efluentes (VELA, 2006), já que se conhecem melhor os fatores que afetam o desempenho do sistema (ZAIAT et al., 2001).

Por favorecer a equalização de seu conteúdo, o ASBR apresenta certa vantagem sobre sistemas contínuos, especialmente em situações em que o efluente é produzido de modo intermitente, no qual há variações significativas de vazão ou de carga orgânica. Sua aplicação no tratamento de águas residuárias de difícil degradação pode se mostrar atrativa (ZAIAT et al., 2001). Este é o caso, por exemplo, de efluentes com compostos tóxicos e xenobióticos, reconhecidamente de maior recalcitrância aos processos de tratamento convencionais.

Um ciclo típico de um ASBR constitui-se de quatro etapas: (1) alimentação, na qual ocorre a entrada de determinado volume a ser tratado; (2) reação, onde há conversão da matéria orgânica a biogás pela ação microbiana; (3) sedimentação, na qual ocorre a separação entre as fases líquida e sólida e; (4) descarga, com a retirada do conteúdo já tratado e clarificado.

A partir da inserção de meio suporte no interior do ASBR, sua configuração é denominada Reator anaeróbio operado em bateladas seqüenciais com biomassa imobilizada (ASBBR). Tal possibilidade apresenta vantagens em relação ao reator sem meio suporte uma vez que se suprimem as incertezas referentes à granulação do lodo e elimina-se a etapa de sedimentação, reduzindo e otimizando o tempo de ciclo do reator.

De acordo com Cohen (2001), na degradação de poluentes, os reatores com biomassa imobilizada apresentam inúmeras vantagens frente aos sistemas operados com biomassa suspensa. Devido à elevada concentração de biomassa e de nutrientes aderidos ao biofilme, aumenta-se a atividade metabólica, ao mesmo tempo em que a matriz extracelular comportase como uma barreira de difusão, conferindo ao sistema resistência à toxidade do composto tratado. 
Segundo Camargo et al. (2002), a inserção de meio suporte é útil em promover maior retenção de biomassa. Entretanto, o meio suporte impõe resistência aos fenômenos de transferência de massa que ocorrem entre a fase líquida e a biomassa anaeróbia. Dessa maneira, podem-se comprometer as velocidades de assimilação de nutrientes e matéria orgânica por parte dos microrganismos, diminuindo a eficiência do reator. Assim, faz-se importante a presença de um sistema efetivo de agitação com o intuito de elevar as velocidades de transferência de massa.

Reatores anaeróbios operados em bateladas seqüenciais com espuma de poliuretano como meio suporte e providos de sistema de agitação tem sido considerados adequados para o tratamento de águas residuárias com baixa carga orgânica e reduzida concentração de sólidos suspensos (RATUSZNEI et al., 2003). Além disso, essa configuração pode ser também adequada para o tratamento de águas residuárias parcialmente solúveis já que agitação eficiente aumentaria a suspensão de partículas e aceleraria a solubilização da matéria orgânica suspensa (PINHO et al., 2005a).

Cubas et al. (2004) estudaram a influência das velocidades de agitação na transferência de massa na fase líquida e no desempenho global de um ASBBR de 4,2 L de volume útil. As velocidades de agitação testadas variaram entre 300 e 1100 rpm. O tempo de ciclo utilizado foi de 8 horas e a água residuária sintética apresentava DQO de aproximadamente $500 \mathrm{mg} / \mathrm{L}$. O sistema apresentou eficiência máxima de remoção de DQO de 78\%. Os autores constataram que o desempenho do reator e o tempo de ciclo ótimo (máxima eficiência) foram afetados pela transferência de massa na fase líquida. Assim, o tempo de ciclo para alcançar a mesma eficiência de remoção da matéria orgânica com 300 rpm foi três vezes maior que o tempo necessário quando o reator operou com 900 rpm.

Miqueleto et al. (2005) estudaram o desempenho de ASBBR com aumento progressivo da concentração de matéria orgânica em substrato de fácil degradação. O reator foi alimentado com glicose nas concentrações de 500, 1000 e 2000 mg/L, com ciclos de 3 e 
8 horas e velocidade de agitação de $300 \mathrm{rpm}$. Quando o reator foi alimentado com concentrações de glicose acima de $1000 \mathrm{mg} / \mathrm{L}$ verificou-se diminuição no desempenho do sistema devido à produção significativa de polímeros extracelulares, que dificultaram a transferência de massa da fase líquida para a fase sólida.

Pinho et al. (2005b) estudaram a influência do tamanho da biopartícula afluente na cinética de degradação de substrato parcialmente solúvel. Como meio suporte foi utilizado espuma de poliuretano de diversos tamanhos $(0,5,1,0,2,0$ e $3,0 \mathrm{~cm}$ de aresta). O reator foi operado com 4,5 L, a $30^{\circ} \mathrm{C}$ e intensidade de agitação de $500 \mathrm{rpm}$. O sistema foi alimentado com substrato sintético com DQO de aproximadamente $1000 \mathrm{mg} / \mathrm{L}$, sendo $50 \%$ correspondente a material em suspensão. Os autores verificaram que o tamanho da biopartícula exerceu influência decisiva no desempenho do processo anaeróbio nestas condições. A velocidade de dissolução foi aparentemente influenciada, principalmente, pelo tamanho da espuma, enquanto o consumo da DQO filtrada envolveu fatores mais complexos.

Os trabalhos apresentados anteriormente reforçam a importância da continuidade nas pesquisas sobre o aprimoramento do ASBBR relacionando sua eficiência global com diferentes condições de operação para diferentes águas residuárias. Assim, procurou-se neste trabalho, avaliar a utilização do ASBBR com biomassa imobilizada em carvão vegetal na degradação de LAS. O meio suporte foi escolhido tendo em vista a menor adsorção apresentada pelos LAS em relação a outros meios suportes (espuma de poliuretano e argila expandida), conforme verificado por Oliveira (2006). 


\section{MATERIAL E MÉTODOS}

Neste trabalho, foi avaliada a degradação do LAS em reator anaeróbio operado em bateladas seqüenciais utilizando carvão vegetal como meio suporte. O fluxograma mostrado na Figura 4.1 detalha as etapas experimentais realizadas neste trabalho.

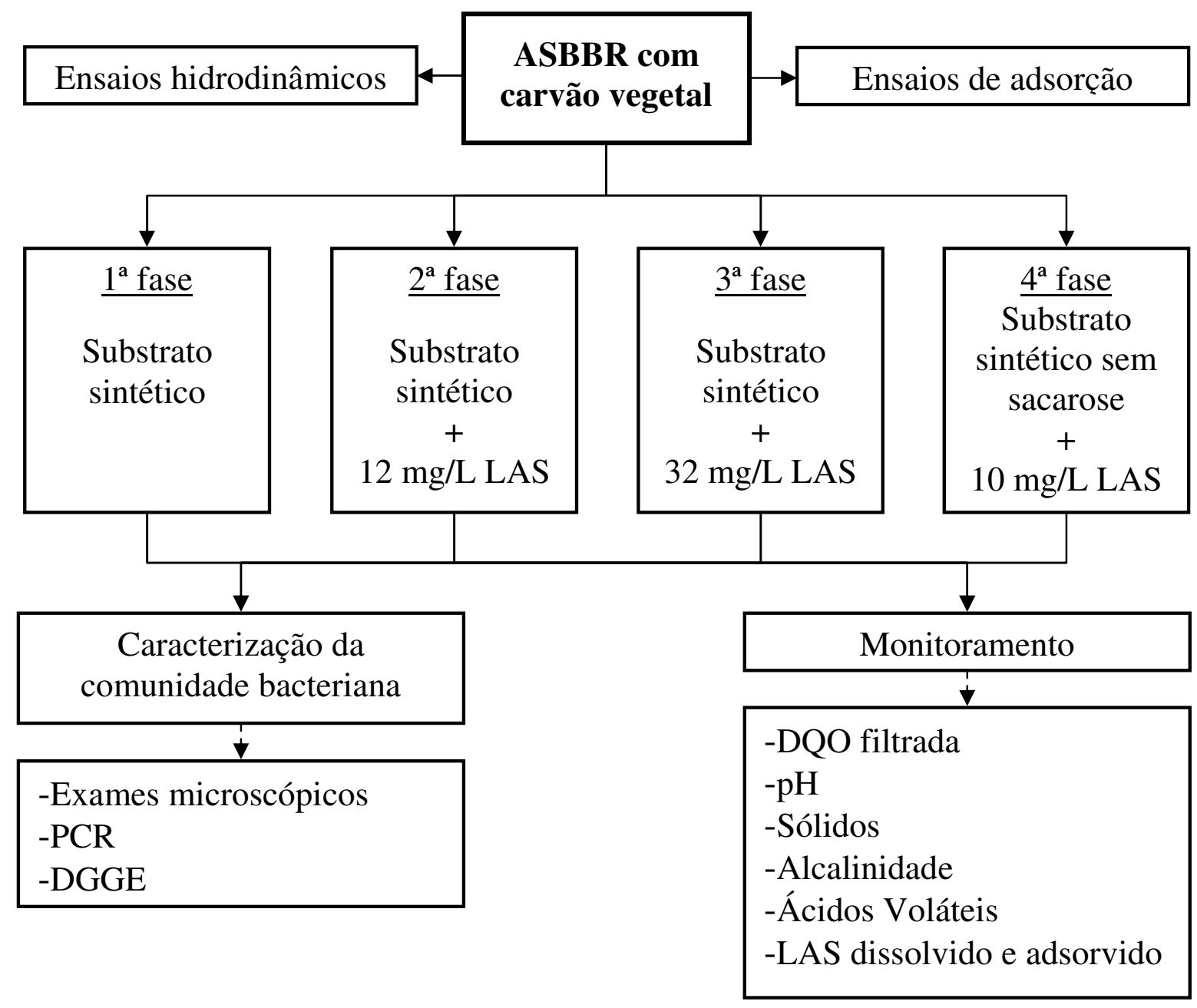

Figura 4.1 Fluxograma experimental geral

\subsection{Descrição do reator}

O reator, confeccionado em vidro borossilicato, consistia de um frasco de $22 \mathrm{~cm}$ de diâmetro e $26 \mathrm{~cm}$ de altura, com volume total de 5 L (Figura 4.2). Contudo, devido ao volume ocupado pelo meio suporte, o volume útil do sistema foi de 2,6 L. A temperatura do reator foi mantida pela circulação de água proveniente de banho térmico (Banho Ultratermostatizado Marconi modelo BTC-9090) a $30 \pm 1^{\circ} \mathrm{C}$. 


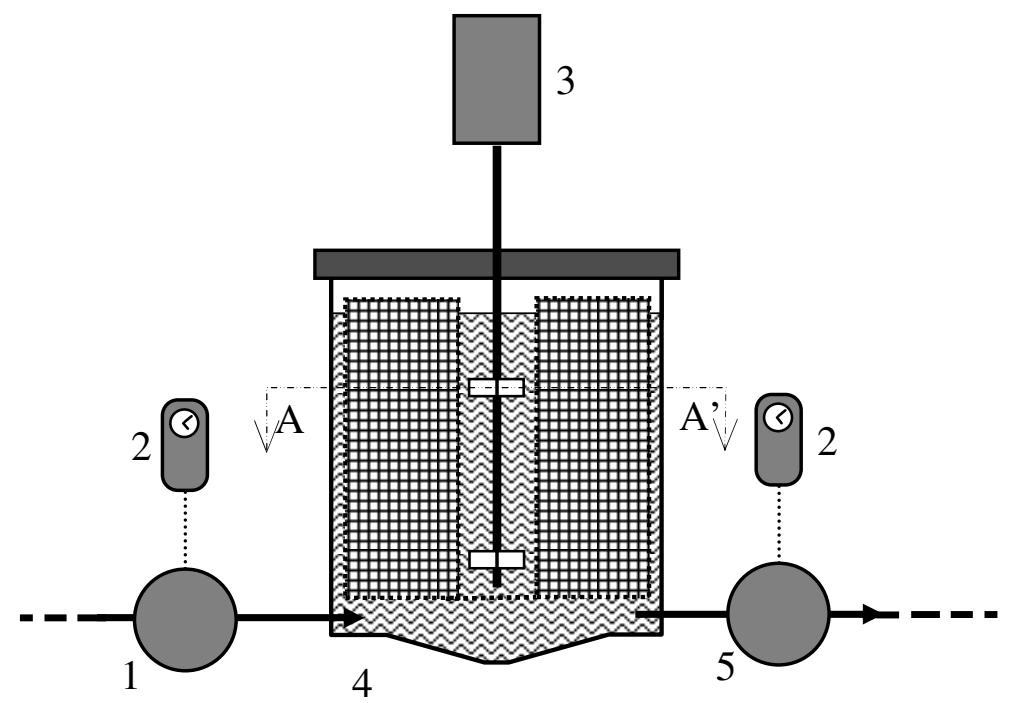

(a)

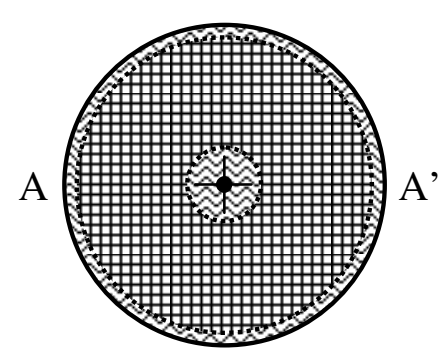

(b) (a)- Esquema geral do reator

1 - Bomba de alimentação

2 - Temporizador

3 - Sistema de agitação

4 - Reator e cesto

5 - Bomba de descarga

(b)- Corte transversal do

reator na altura de um

impelidor

Figura 4.2 Esquema do reator anaeróbio operado em bateladas seqüenciais

Alimentação e descarga eram realizadas por duas bombas tipo diafragma ProMinent modelo $\alpha$ ligadas a temporizadores pré-programados e automatizados. Considerando um tempo de ciclo de 12 horas, os tempos de alimentação, de reação e de descarga utilizados foram os seguintes: 7, 702 e 11 minutos, respectivamente. Ao final da descarga das bateladas, foi deixado intervalo de segurança de 1 minuto para o acionamento da bomba de alimentação. Este intervalo evitava o funcionamento conjunto das duas bombas utilizadas.

$\mathrm{O}$ meio suporte era confinado em um cesto, acomodado no interior do reator. $\mathrm{O}$ cesto foi fabricado em aço inox 316 perfurado e apresentava um cilindro central oco de $4 \mathrm{~cm}$ de diâmetro, por onde era introduzida a barra de agitação, na qual, os propulsores estavam afixados. Foram utilizados dois propulsores tipo turbina com quatro pás planas cada um medindo $3 \mathrm{~cm}$ de diâmetro. 


\subsection{Inóculo}

Utilizou-se como inóculo lodo proveniente de reator UASB utilizado no tratamento de resíduos de suinocultura, obtido junto ao Departamento de Engenharia Rural da Universidade Estadual Paulista (UNESP), Campus de Jaboticabal - SP.

O reator foi inoculado de acordo com o procedimento experimental utilizado por Pinho et al. (2004). Para isso, o lodo foi batido em liquidificador até se obter pasta homogênea. Amostras desse material foram retiradas para determinação de sólidos totais, sólidos totais voláteis e fixos de acordo com metodologia descrita em Standard Methods for Examination of Water and Wastewater (APHA, 1998). Esse inóculo foi misturado manualmente ao carvão previamente selecionado. O conjunto carvão-biomassa foi deixado em repouso por 24 horas, em frasco apropriado, antes de ser colocado no cesto e acomodado no reator.

\subsection{Material suporte}

O carvão vegetal utilizado como meio suporte foi quebrado manualmente e peneirado de acordo com metodologia realizada por Oliveira (2006). As partículas de carvão vegetal selecionadas foram aquelas com dimensões entre 4,70 mm e 5,16 mm. A caracterização do carvão vegetal está apresentada na Tabela 4.1.

Tabela 4.1 Caracterização do carvão vegetal

\begin{tabular}{lc}
\hline Forma & Pellet irregular \\
Densidade aparente $(\mathrm{g} / \mathrm{mL})$ & 0,51 \\
Diâmetro equivalente $(\mathrm{cm})$ & 0,5 \\
Porosidade & 0,43 \\
Área superficial $\left(\mathrm{m}^{2} / \mathrm{g}\right)$ & 3,51 \\
\hline Fonte: OLIVEIRA $(2006)$ &
\end{tabular}

A massa de carvão vegetal utilizada nos ensaios hidrodinâmicos e de adsorção, bem como durante a operação do reator foi de $620 \mathrm{~g}$. 


\subsection{Composição do substrato sintético}

O surfactante utilizado neste trabalho foi o dodecilbenzeno sulfonado de sódio, também conhecido como LAS comercial. Este composto foi fabricado pela empresa Sigma e apresentava pureza de $80 \%$. O restante (20\%) corresponde a sulfato de sódio (15\%) e impurezas orgânicas (5\%) provenientes da fabricação (HOUSE \& FARR, 1989).

O reator foi alimentado com substrato sintético acrescido de LAS (Tabela 4.2 e 4.3) cujo armazenamento se deu sob refrigeração. A composição do substrato sintético foi adaptada de Torres (1992). Algumas modificações foram necessárias, como por exemplo, a não inclusão de óleo e detergente de cozinha, uma vez que, a presença dos mesmos poderia prejudicar as análises de LAS. Nesta nova composição também não foram adicionados amido e celulose para evitar a excessiva formação de polímeros extracelulares e, dessa forma, evitar a colmatação do leito (DUARTE, 2006). Além disso, o extrato de carne foi substituído pelo extrato de levedura, em virtude deste ser rico em vitaminas do complexo B e ter sido utilizado com sucesso nos processos de degradação anaeróbia de fenol (MAINTINGUER, 2004).

O substrato sintético utilizado, sem adição de LAS, apresentou DQO média de $479 \pm 26 \mathrm{mg} / \mathrm{L}$.

Tabela 4.2 Composição do substrato sintético

\begin{tabular}{lc}
\hline \multicolumn{1}{c}{ Nutrientes } & Concentração \\
\hline Extrato levedura & $500 \mathrm{mg} / \mathrm{L}$ \\
$\mathrm{NaHCO}_{3}$ & $400 \mathrm{mg} / \mathrm{L}$ \\
Sacarose & $80 \mathrm{mg} / \mathrm{L}$ \\
Solução de sais (Tabela 4.3) & $5 \mathrm{~mL} / \mathrm{L}$ \\
\hline
\end{tabular}

Fonte: modificado de Torres (1992) 
Tabela 4.3 Composição da solução de sais

\begin{tabular}{lc}
\hline \multicolumn{1}{c}{ Sais Inorgânicos } & Concentração (g/L) \\
\hline $\mathrm{NaCl}$ & 50,0 \\
$\mathrm{MgCl}_{2} \bullet 6 \mathrm{H}_{2} \mathrm{O}$ & 1,4 \\
$\mathrm{CaCl}_{2} \cdot 2 \mathrm{H}_{2} \mathrm{O}$ & 0,9 \\
\hline
\end{tabular}

Fonte: Torres (1992)

Os componentes do substrato sintético eram preparados da seguinte maneira: (a) a solução de sais era preparada previamente e mantida em frasco âmbar de 1,0 L sob refrigeração; (b) os demais componentes do substrato eram preparados semanalmente e mantidos em frascos tampados sem umidade; (c) LAS era mantido sob refrigeração na forma de solução estoque a $13 \mathrm{~g} / \mathrm{L}$.

O substrato sintético, armazenado sob refrigeração antes da alimentação, era preparado semanalmente pelo seguinte protocolo:

a) Enchia-se parcialmente o galão de alimentação (volume total de 13 L) com água da rede pública de abastecimento;

b) Adicionava-se a sacarose, extrato de levedura e bicarbonato de sódio;

c) Adicionava-se a solução de sais;

d) Agitava-se vigorosamente o galão para solubilização total dos componentes previamente adicionados;

e) Adicionava-se LAS à solução;

f) Completava-se o volume do galão até atingir a concentração estabelecida dos componentes do substrato sintético.

\subsection{Etapas de operação do reator}

A operação do reator foi dividida em 4 etapas, determinadas conforme a composição da alimentação (Tabela 4.4). O tempo de ciclo utilizado para a primeira etapa foi de 24 horas; e nas etapas posteriores, 12 horas. 
Tabela 4.4 Etapas de operação do reator

\begin{tabular}{cccc}
\hline Etapa & Composição da alimentação & $\begin{array}{c}\text { Duração } \\
\text { (dias) }\end{array}$ & $\begin{array}{c}\text { Tempo de } \\
\text { ciclo } \\
\text { (horas) }\end{array}$ \\
\hline I & Substrato sintético & 63 & 24 \\
II & Substrato sintético + LAS 12 $\pm 3 \mathrm{mg} / \mathrm{L}$ & 84 & 12 \\
III & Substrato sintético + LAS 32 $\pm 5 \mathrm{mg} / \mathrm{L}$ & 48 & 12 \\
IV & Substrato sintético sem sacarose + LAS $10 \pm 2 \mathrm{mg} / \mathrm{L}$ & 61 & 12 \\
\hline
\end{tabular}

Considerando que os microrganismos apresentam preferência metabólica por substratos de fácil degradação, decidiu-se na quarta etapa retirar a sacarose da alimentação com o intuito de diminuir a concentração dos co-substratos e elevar a degradação do LAS.

\subsection{Análises físico-químicas e cromatográficas}

As análises de DQO, sólidos totais (ST) e sólidos voláteis (SV) foram realizadas de acordo com APHA (1998). Análises volumétricas de ácidos graxos totais e alcalinidade a bicarbonato foram realizadas como descrito por Dillalo \& Albertson (1961) e Dillalo \& Albertson (1961) modificado por Ripley et al. (1986), respectivamente. Todas essas análises foram realizadas com freqüência de 2 vezes por semana (Tabela 4.5). O LAS foi determinado por cromatografia líquida de alta pressão (HPLC), segundo método desenvolvido por Duarte (2006). As condições cromatográficas empregadas estão descritas na Tabela 4.6. 
Tabela 4.5 Análises de monitoramento do reator

\begin{tabular}{lcc}
\hline Parâmetro & Método & Referência \\
\hline $\mathrm{pH}$ & potenciométrico & APHA (1998) \\
DQO filtrada $(\mathrm{mg} / \mathrm{L})$ & espectrofotométrico & APHA (1998) \\
Ácidos voláteis totais $\left(\mathrm{mg}_{\mathrm{HAc}} / \mathrm{L}\right)$ & titulométrico & DILLALO \& \\
& & ALBERTSON (1961) \\
Alcalinidade $\left(\mathrm{mg}_{\left.\mathrm{CaCO}_{3} / \mathrm{L}\right)}\right.$ & titulométrico & DLILLALO \& \\
& & modificado por RIPLEY \\
LAS $\left(\mathrm{mg}_{\mathrm{LAS}} / \mathrm{L}\right)$ & ct al. (1986) & DUARTE (2006) \\
\hline
\end{tabular}

Tabela 4.6 Condições cromatográficas para quantificação do LAS

\begin{tabular}{ll}
\hline Coluna & C-8 Supelco, $5 \mu \mathrm{m}, 15 \mathrm{~cm}$ x 4,6 mm \\
Solvente A & solução de $\mathrm{NaClO}_{4} 0,075 \mathrm{M}$ em água ultra purificada \\
Solvente B & Metanol puro \\
Fluxo & $0,5 \mathrm{~mL} / \mathrm{min}$ \\
Detector & fluorescência, com $\lambda_{\text {excitação }} 225 \mathrm{~nm}$ e $\lambda_{\text {emissão }} 290 \mathrm{~nm}$ \\
Forno & $35^{\circ} \mathrm{C}$ \\
\hline
\end{tabular}

\subsection{Ensaios Hidrodinâmicos}

Para obter o tempo de mistura e determinar a freqüência de agitação utilizada no decorrer de toda a operação, foram realizados preliminarmente ensaios hidrodinâmicos de estímulo/resposta ao pulso, nos quais se utilizou solução de ácido sulfúrico $1 \mathrm{M}$ como traçador, sendo o $\mathrm{pH}$ da fase líquida monitorada por método potenciométrico.

O reator foi preenchido com meio suporte livre de biomassa e testou-se frequiências de agitação de 200 a $700 \mathrm{rpm}$, com incrementos de $100 \mathrm{rpm}$. Todos os ensaios foram realizados em duplicata. Os valores de $\mathrm{pH}$ obtidos em resposta ao pulso foram plotados em função do tempo e normalizados para cada freqüência de agitação. 
Os dados foram analisados com o software Microcal Origin $6.0^{\circledR}$ e ajustados para o modelo sigmoidal Boltzmann. Assim, pôde ser calculado o tempo de mistura $\left(t_{M}\right)$ do reator, conforme realizado por Silva (2005).

A Equação 4.1 representa matematicamente o modelo sigmoidal.

$$
\mathrm{y}=\frac{\mathrm{pH}_{\mathrm{f}}-\mathrm{pH}}{\mathrm{pH}_{\mathrm{f}}-\mathrm{pH}_{0}}=\frac{\mathrm{y}_{\mathrm{i}}-\mathrm{y}_{\mathrm{f}}}{1+\mathrm{e}^{\frac{\mathrm{t}-\mathrm{t}_{0}}{\tau}}}+\mathrm{y}_{\mathrm{f}}
$$

$\mathrm{Na}$ equação 4.1, y é o valor normalizado do $\mathrm{pH}$; $\mathrm{pH}_{\mathrm{f}}$ é o $\mathrm{pH}$ final, atingido após a estabilização da resposta ao pulso; $\mathrm{pH}_{0}$ é o $\mathrm{pH}$ inicial da água no reator, antes do pulso; $\mathrm{y}_{\mathrm{i}}$ é o valor de y quando $\mathrm{pH}$ igual a $\mathrm{pH}_{0}$ (igual a 1); $\mathrm{y}_{\mathrm{f}}$ é o valor de y quando o $\mathrm{pH}$ é igual a $\mathrm{pH}_{\mathrm{f}}$ (igual a 0 ); $\mathrm{t}_{0}$ é o tempo correspondente ao centro da sigmóide e $\tau$ é a constante de tempo.

Admitindo-se que, o tempo de mistura $\left(\mathrm{t}_{\mathrm{M}}\right)$ significa o tempo para se atingir $99,9 \%$ da resposta final, ou seja, quando $\left(\mathrm{pH}_{\mathrm{f}}-\mathrm{pH}\right)$ for igual a $\left[0,001\left(\mathrm{pH}_{\mathrm{f}}-\mathrm{pH}_{0}\right)\right], \mathrm{t}_{\mathrm{M}}$ pode ser calculado pela resolução das equações 4.2 a 4.6 .

$$
\begin{gathered}
y=\frac{1-0}{1+e^{\frac{t-t_{0}}{\tau}}+0} \\
0,001=\frac{1}{1+e^{\frac{t_{M}-t_{0}}{\tau}}}
\end{gathered}
$$

$\ln 0,001=\ln \frac{1}{1+e^{\frac{t_{M}-t_{0}}{\tau}}}=\ln 1-\ln 1-\ln e^{\frac{t_{M}-t_{0}}{\tau}}$

$-6,91=\frac{-t_{M}+t_{0}}{\tau}$

$$
t_{M}=6,91 \cdot \tau+t_{0}
$$

\subsection{Ensaios de adsorção}

Ensaios de adsorção foram realizados com a finalidade de verificar o potencial adsortivo do carvão vegetal livre de biomassa, em relação ao LAS, em função do tempo. 
Os ensaios foram realizados no próprio reator e simularam um ciclo de operação. $\mathrm{O}$ reator foi preenchido com carvão e sua alimentação consistiu de solução de LAS. Dois ensaios foram realizados, testando-se as concentrações de 27 e $57 \mathrm{mg} / \mathrm{L}$.

Amostras em duplicata foram coletadas da solução inicial, imediatamente após o enchimento do reator e após intervalos de tempo regulares até completar 24 horas.

Por meio da comparação entre a concentração de LAS na solução inicial e durante os ensaios, foi possível calcular a massa de LAS adsorvida ao meio suporte ao longo do tempo e assim, estimar o tempo de contato necessário para a saturação do carvão presente no sistema.

\subsection{Quantificação do LAS}

\subsubsection{Extração do LAS adsorvido no material suporte}

As análises do LAS foram realizadas em HPLC, conforme método desenvolvido por Duarte (2006). Para isso, amostras em triplicata do carvão foram retiradas e mantidas em estufa a $110^{\circ} \mathrm{C}$ por 24 horas. Após esse período as amostras foram pesadas e suas massas, anotadas. Posteriormente, aplicou-se o protocolo de extração do LAS por ultra-som nas amostras, que consistiu em:

a) À amostra de carvão, adicionou-se $50 \mathrm{~mL}$ de metanol puro;

b) Material suporte mais metanol foram levados a ultra-som durante 30 minutos a temperatura de aproximadamente $50^{\circ} \mathrm{C}$;

c) Os pedaços de carvão da solução foram retirados, coletando-se a fase líquida;

d) As etapas (b) e (c) foram repetidas mais duas vezes;

e) Ao suporte adicionou-se $20 \mathrm{~mL}$ de água destilada;

f) As etapas (c) e (d) foram repetidas;

g) A solução formada pelo metanol coletado em cada etapa mais a água foi filtrada em membrana de $0,2 \mu \mathrm{m}$;

h) Evaporou-se o extrato metanólico em banho-maria a $\left(60^{\circ} \mathrm{C}\right)$ até o volume ser reduzido a aproximadamente $20 \mathrm{~mL}$; 
i) A solução resultante foi transferida para uma coluna de troca iônica (SAX).

\subsubsection{Purificação da Amostra Contendo LAS em Coluna de Troca Iônica}

Antes de sua utilização, as colunas de troca iônica (SAX) foram condicionadas com 5 $\mathrm{mL}$ de hexano, $5 \mathrm{~mL}$ de metanol puro e $5 \mathrm{~mL}$ de água ultra purificada.

A limpeza da amostra consistiu na transferência da solução proveniente da extração por ultra-som para a coluna SAX já condicionada. A coluna foi então lavada com $5 \mathrm{~mL}$ de solução metanol/água na proporção 35:65 (v/v) e essa fração, desprezada. O surfactante foi eluído com $5 \mathrm{~mL}$ de $\mathrm{HCl} 4 \mathrm{~N}$ em metanol, e em seguida, com $1 \mathrm{~mL}$ de metanol. Coletou-se essas frações em balão volumétrico de $50 \mathrm{~mL}$ e 1 gota de fenolftaleína (solução $1 \%$ em metanol) foi adicionada para posterior neutralização com $\mathrm{NaOH} 4 \mathrm{~N}$. Adicionou-se cerca de 25 mL de água ultra purificada para completar o volume do balão volumétrico e transferiu-se esse volume para a coluna de fase sólida C18.

\subsubsection{Concentração do LAS em Coluna de Fase Sólida}

A coluna $\mathrm{C} 18$ foi condicionadas passando-se $5 \mathrm{~mL}$ de metanol e em seguida $5 \mathrm{~mL}$ de água ultra purificada. Então a amostra proveniente da coluna SAX, livre de impurezas e neutralizada, foi transferida para a coluna C18 previamente condicionada. O LAS retido nessa coluna foi extraído com $5 \mathrm{~mL}$ de metanol. Essa fração foi coletada em balão volumétrico (10 $\mathrm{mL}$ ) aferido com água ultra purificada. A amostra foi filtrada em membrana de $0,22 \mu \mathrm{m}$ para análise em HPLC.

\subsection{Análise da diversidade microbiana}

\subsubsection{Exames microscópicos}

Amostras microbianas dos reatores foram retiradas do inóculo e do reator em cada fase de operação e examinadas em microscópio Leica DMLB em contraste de fase. Para isso, em lâminas de vidro previamente limpas com álcool, foram colocadas finas camadas de ágar (2\%). Após a solidificação do ágar, uma gota de amostra foi adicionada, recoberta com 
lamínula e examinada ao microscópio. A captura das imagens foi realizada por câmera Optronics e o processamento por meio do software Image Pro Plus versão 3.0.1.

\subsubsection{Técnicas de Biologia Molecular}

Ao final da operação do reator, amostras de carvão e do lodo utilizado para inocular o reator foram coletadas, embaladas e congeladas até o momento da extração. As amostras foram centrifugadas a $6.000 \mathrm{rpm}$, a $4^{\circ} \mathrm{C}$ por 10 minutos. $\mathrm{O}$ pellet obtido foi lavado com 5,0 mL de tampão PBS (137,0 mM de $\mathrm{NaCl} ; 2,6 \mathrm{mM}$ de $\mathrm{KCl} ; 1,7 \mathrm{mM}$ de $\mathrm{KH}_{2} \mathrm{PO}_{4} ; \mathrm{pH}$ 7,4). Posteriormente, foi realizada a extração do ácido nucléico de acordo com o protocolo realizado por Griffiths et al. (2000), utilizando glass beads, e fenol:clorofórmio:tampão $(1: 1: 1, \mathrm{v} / \mathrm{v})$.

A partir do DNA extraído das amostras, foram obtidos fragmentos do gene do DNAr 16S utilizando-se primers para o Domínio Bacteria, e condições de amplificação descritas por Nielsen et al. (1999) (Tabela 4.7). Na reação em cadeia da polimerase (PCR) foi utilizado termociclador “Gene Amp. PCR System 2400” (Perkin-Elmer Cetus, Norwalk, Conn.). Os primers (Tabela 4.8) foram sintetizados pela empresa Invitrogem®.

Tabela 4.7 Condições utilizadas na reação em cadeia da polimerase

\begin{tabular}{|c|c|c|c|c|c|c|}
\hline $\begin{array}{c}\text { Número } \\
\text { de } \\
\text { ciclos }\end{array}$ & $\begin{array}{c}\text { Desnaturação } \\
\text { inicial }\end{array}$ & Desnaturação & Anelamento & Extensão & $\begin{array}{l}\text { Final da } \\
\text { extensão }\end{array}$ & Resfriamento \\
\hline \multirow{2}{*}{35} & $94^{\circ} \mathrm{C}$ & $94^{\circ} \mathrm{C}$ & $38^{\circ} \mathrm{C}$ & $72^{\circ} \mathrm{C}$ & $72^{\circ} \mathrm{C}$ & \multirow{2}{*}{$4^{\circ} \mathrm{C}$} \\
\hline & 5 minutos & 45 segundos & 1 minuto & 2 minutos & 10 minutos & \\
\hline
\end{tabular}

Tabela 4.8 Primers filogenéticos utilizados para o Domínio Bacteria

\begin{tabular}{ll}
\hline \multicolumn{1}{c}{ Primer } & \multicolumn{1}{c}{ Seqüência $\left(5^{\prime} \rightarrow 3^{\prime}\right)$} \\
\hline 968FGC & AACGCGAAGAACCTTAC \\
GC clamp & CGCCCGGGGCGCGCCCCGGGCGGGGCGGGGGCACGGGGGG \\
$1392 \mathrm{R}$ & ACGGGCGGTGTGTAC \\
\hline
\end{tabular}

Fonte: NIELSEN et al. (1999). 
A eletroforese em gel de agarose foi aplicada para avaliar o produto resultante da extração do ácido nucléico e da amplificação por PCR. O procedimento experimental foi o mesmo, diferindo apenas no marcador molecular. Para verificar o produto da extração do ácido nucléico usou-se gel de agarose $1 \%$ e High, como marcador de elevada massa molecular. Para avaliar o produto da amplificação por PCR foram usados agarose 1\% e Low, como marcador de baixa massa molecular.

A técnica de Eletroforese em gel de gradiente desnaturante (DGGE) foi realizada segundo o protocolo de Muyzer et al. (1993) e tem por objetivo a separação dos fragmentos dos genes amplificados por PCR. A separação desses fragmentos ocorre de acordo com o grau de desnaturação da dupla hélice de DNA, sob a ação de agentes desnaturantes como uréia e formamida. Para o Domínio Bacteria foram utilizados gradiente desnaturante de 30-70\%, com tempo de corrida de $16 \mathrm{~h}, 75 \mathrm{~V}$ e temperatura de $65^{\circ} \mathrm{C}$. Em seguida, o gel foi corado com brometo de etídio por 20 minutos e depois transferido para o fotodocumentador Eagle Eye TM III (Stratagene). A visualização das bandas foi analisada pelo software Eagle Slight UV, sob exposição à UV de $254 \mathrm{~nm}$. 


\section{RESULTADOS E DISCUSSÃO}

\subsection{Ensaios Hidrodinâmicos}

Nas Figuras 5.1 a 5.6 estão representados os valores de pH normalizados em função do tempo obtidos antes e após o pulso do traçador. A análise gráfica revelou diminuição sigmoidal do $\mathrm{pH}$ do sistema. Assim, por meio do software Microcal Origin $6.0^{\circledR}$, os dados experimentais foram ajustados ao modelo sigmoidal Boltzmann para cada frequiência de agitação testada, conforme realizado por Silva (2005).

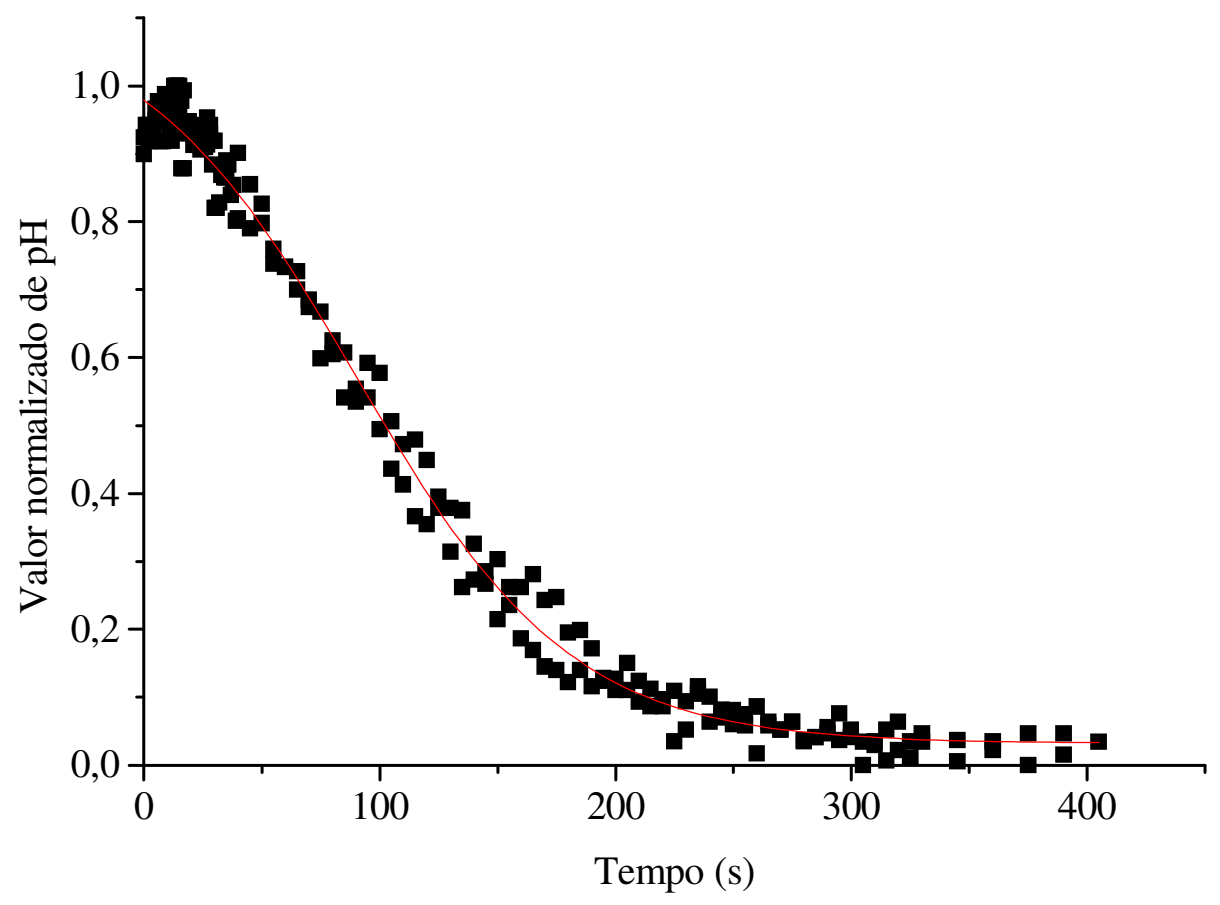

Figura 5.1 Ajuste médio do modelo de Boltzmann aos valores normalizados de $\mathrm{pH}$ do sistema a $200 \mathrm{rpm}$ 


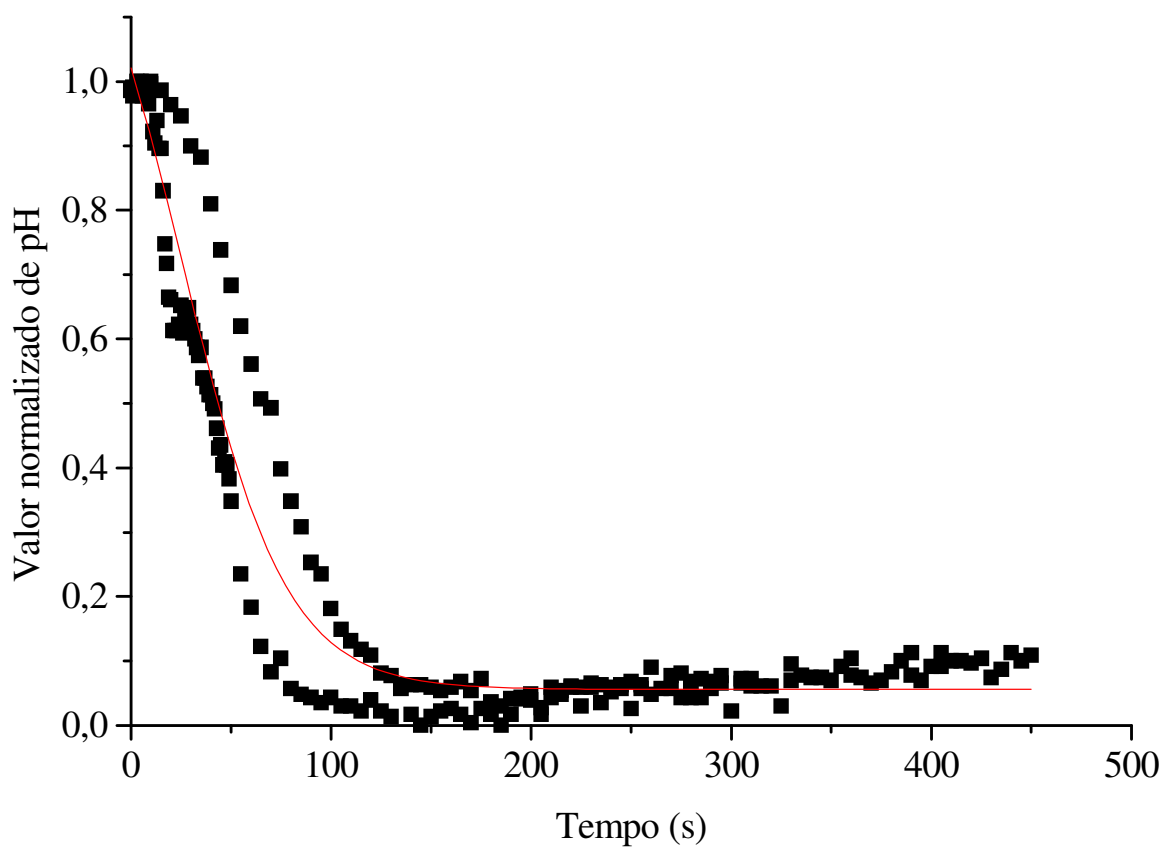

Figura 5.2 Ajuste médio do modelo de Boltzmann aos valores normalizados de $\mathrm{pH}$ do sistema a $300 \mathrm{rpm}$

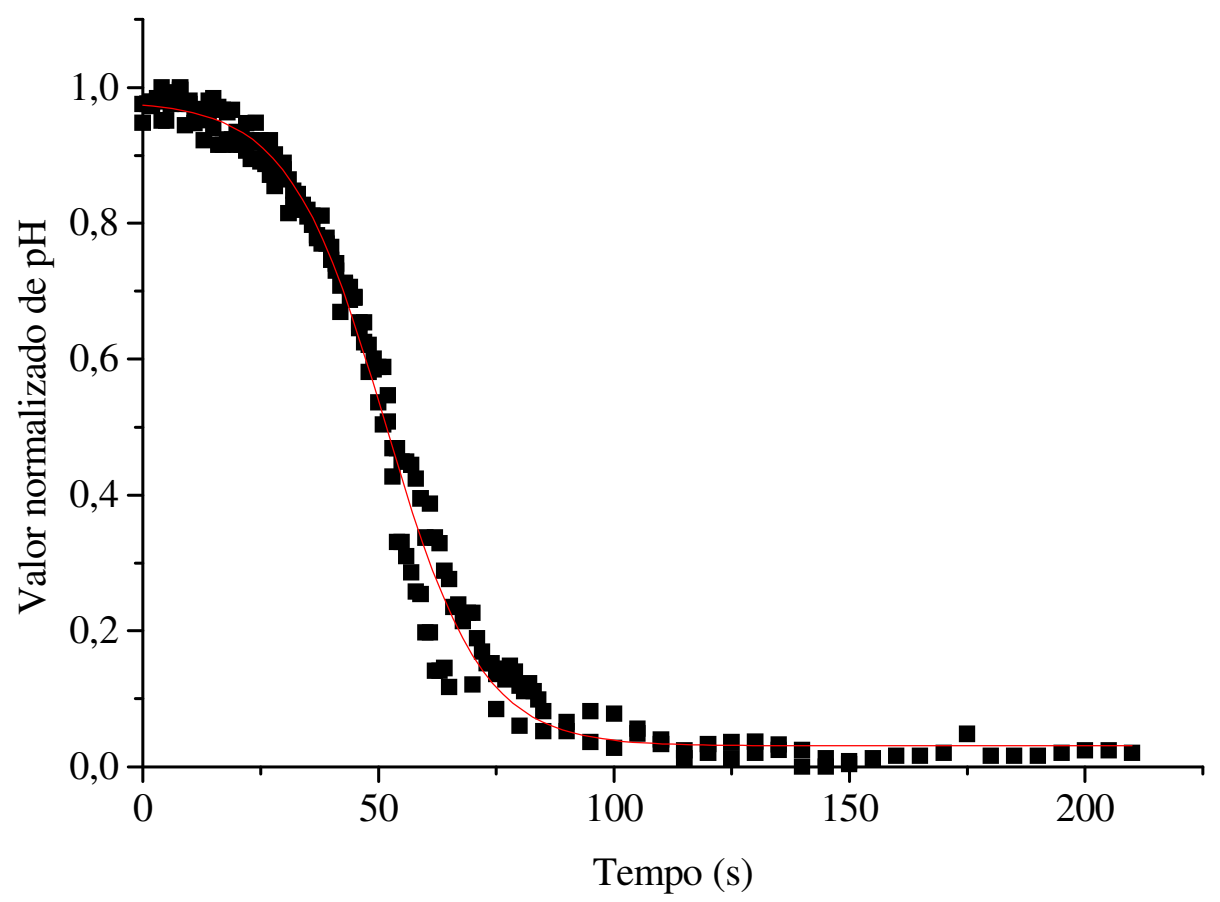

Figura 5.3 Ajuste médio do modelo de Boltzmann aos valores normalizados de $\mathrm{pH}$ do sistema a $400 \mathrm{rpm}$ 


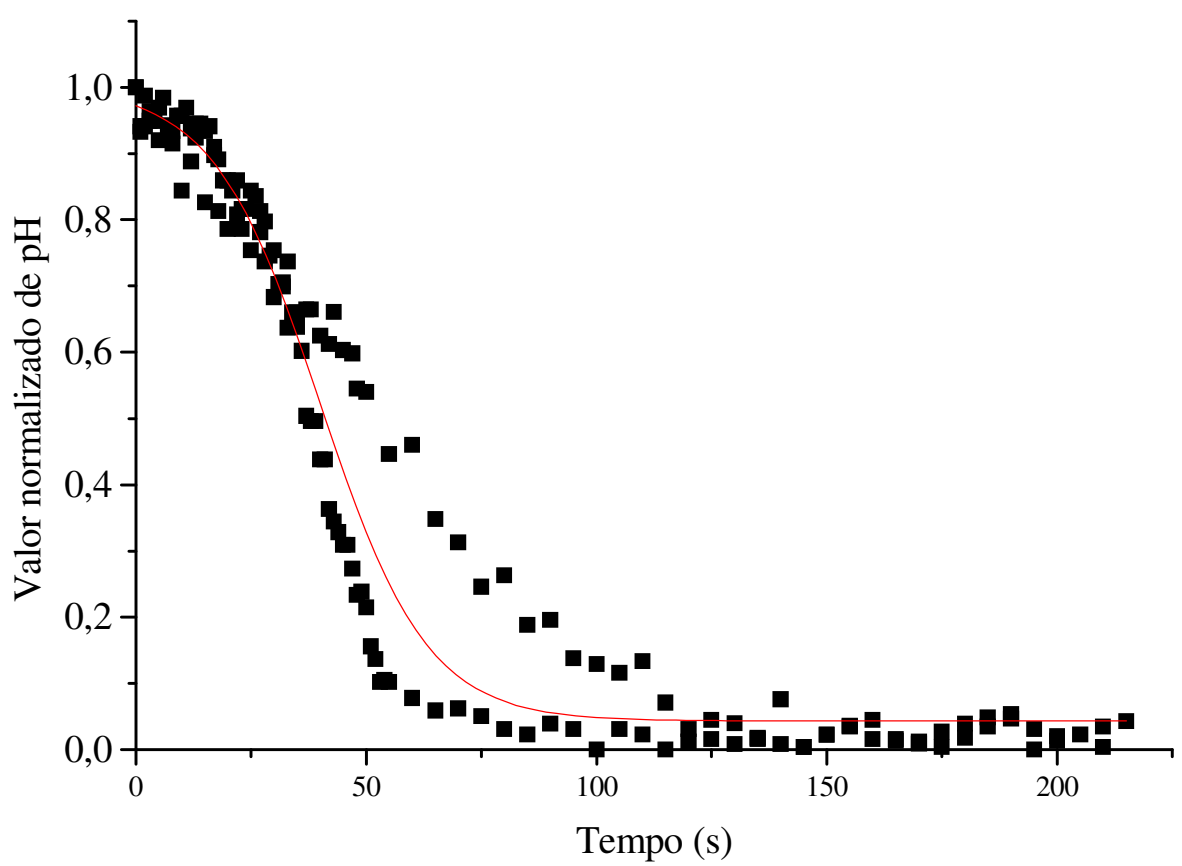

Figura 5.4 Ajuste médio do modelo de Boltzmann aos valores normalizados de $\mathrm{pH}$ do sistema a $500 \mathrm{rpm}$

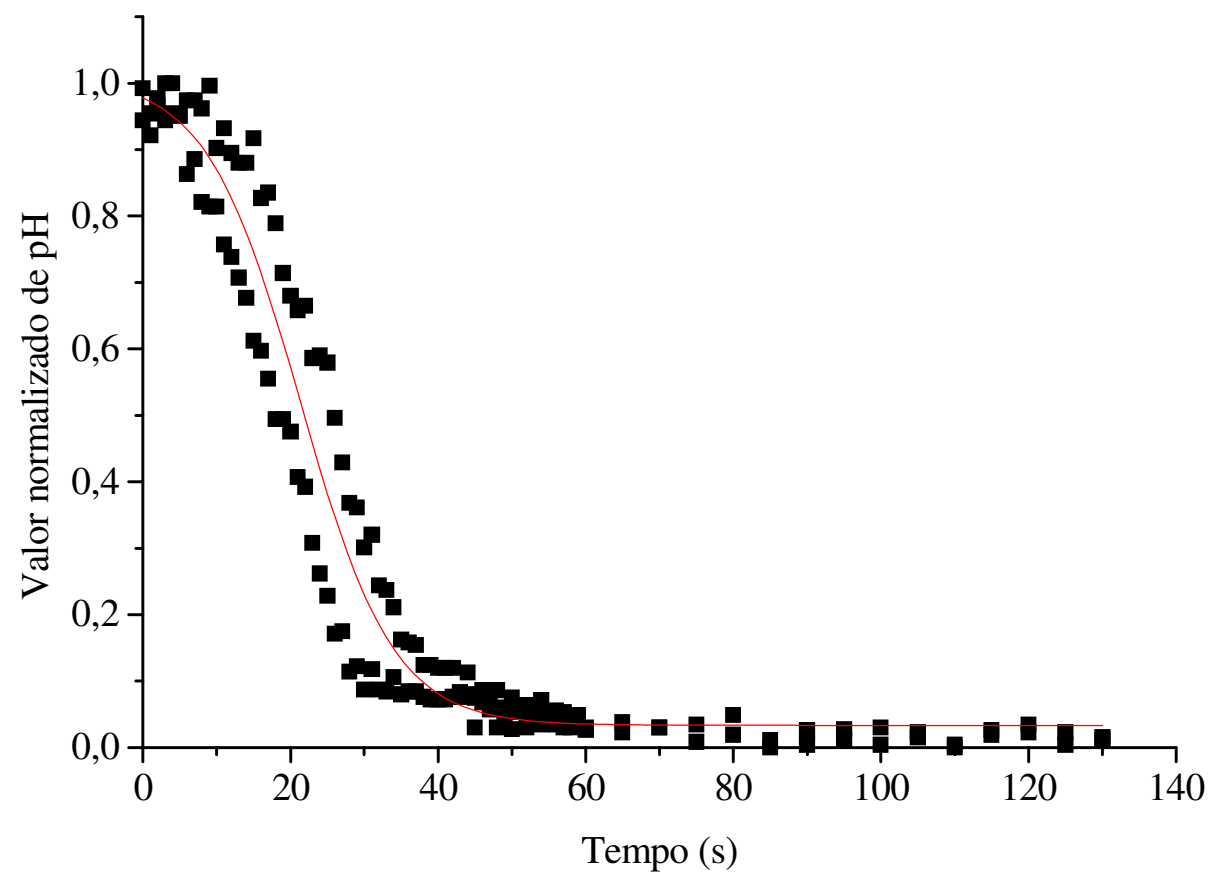

Figura 5.5 Ajuste médio do modelo de Boltzmann aos valores normalizados de $\mathrm{pH}$ do sistema a $600 \mathrm{rpm}$ 


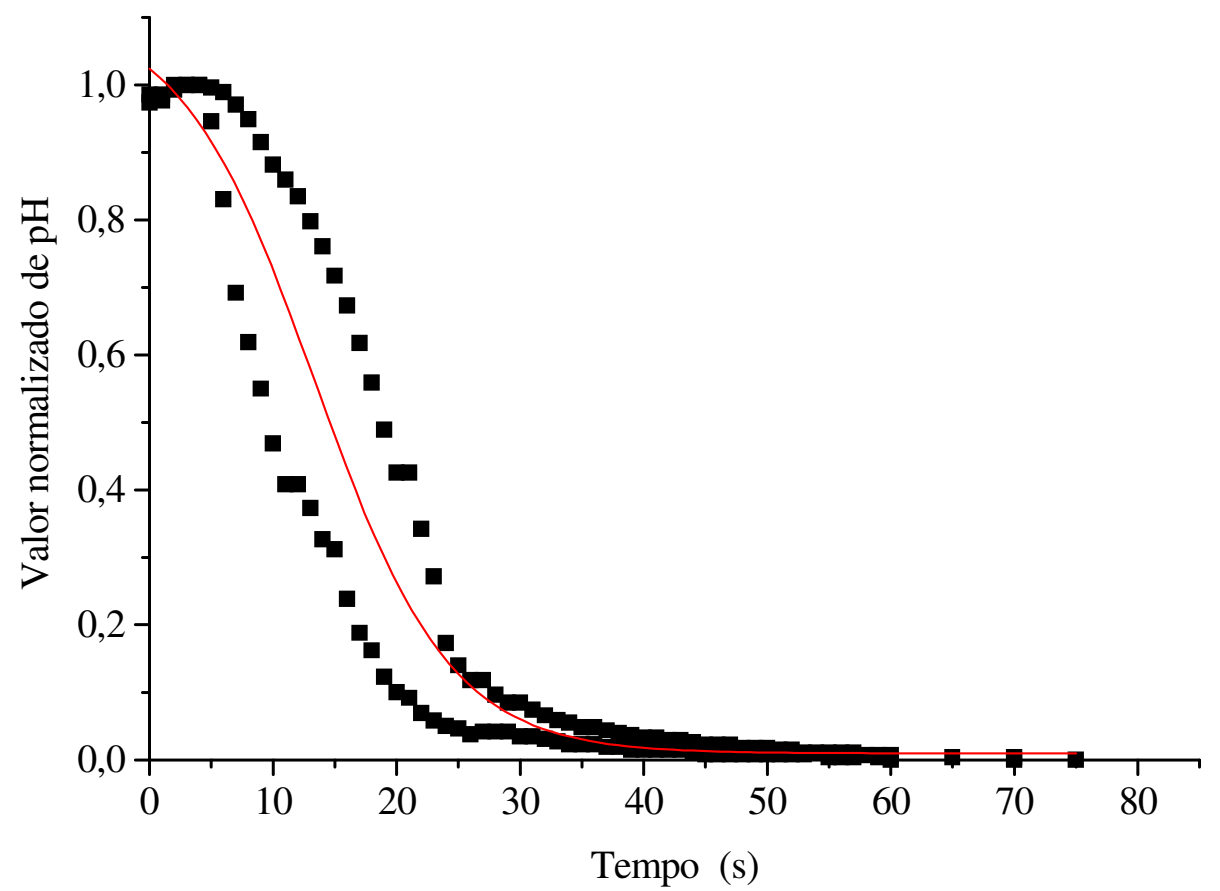

Figura 5.6 Ajuste médio do modelo de Boltzmann aos valores normalizados de $\mathrm{pH}$ do sistema a $700 \mathrm{rpm}$

A Tabela 5.1 apresenta os valores de tempo de mistura $\left(t_{M}\right)$ calculados para cada freqüência de agitação aplicada. A Figura 5.7 apresenta o perfil de cada $t_{M}$ calculado com a variação na freqüência de agitação durante os ensaios hidrodinâmicos.

Tabela 5.1 Valores da Constante de tempo $(\tau)$, do Centro da Sigmóide $\left(\mathrm{t}_{0}\right)$ e do Tempo de Mistura $\left(\mathrm{t}_{\mathrm{M}}\right)$, calculados pelo modelo de Boltzmann para as velocidades de agitação aplicadas ao sistema nos ensaios hidrodinâmicos

\begin{tabular}{cccc}
\hline Agitação $(\mathrm{rpm})$ & $\tau(\mathrm{s})$ & $\mathrm{t}_{0}(\mathrm{~s})$ & $\mathrm{t}_{\mathrm{M}}(\mathrm{s})$ \\
\hline 200 & 46 & 90 & 406 \\
300 & 26 & 26 & 206 \\
400 & 10 & 51 & 122 \\
500 & 12 & 40 & 120 \\
600 & 6 & 21 & 65 \\
700 & 5 & 13 & 51 \\
\hline
\end{tabular}




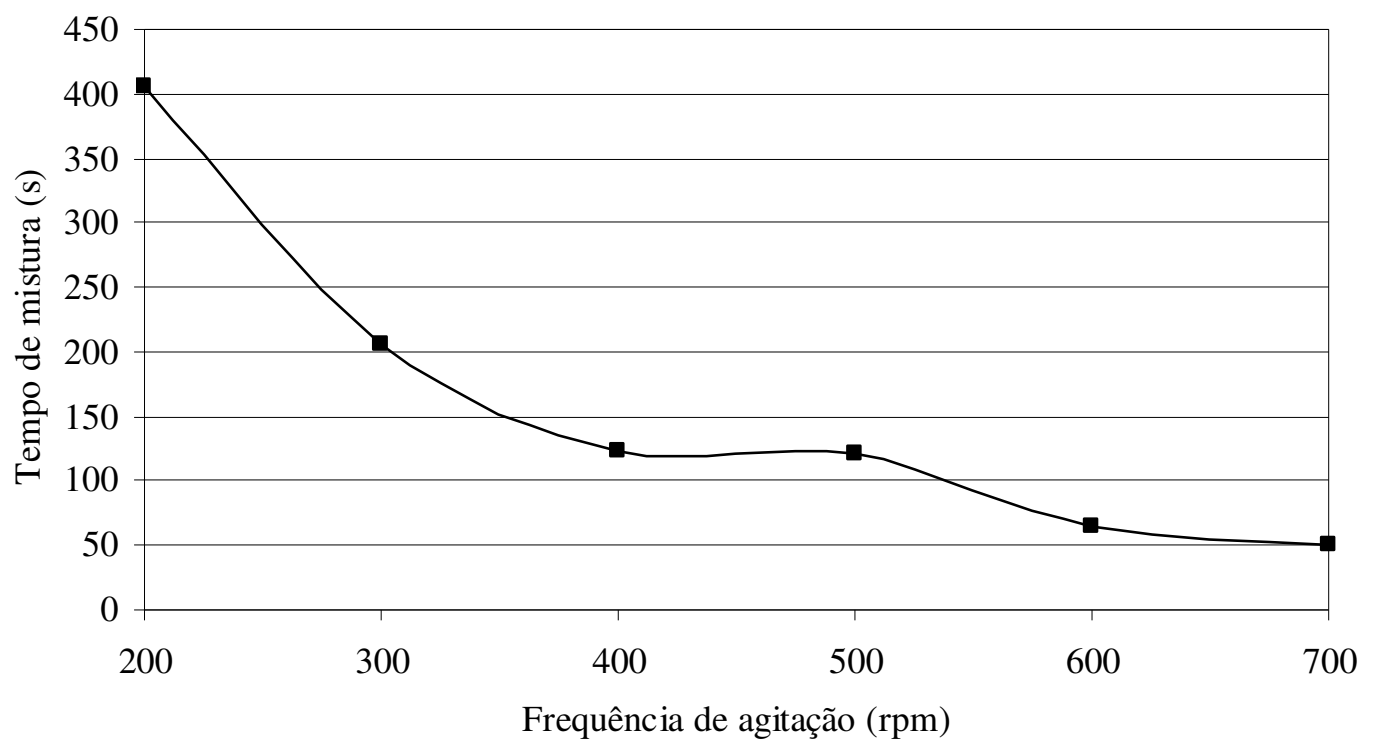

Figura 5.7 Tempo de mistura em função da freqüência de agitação nos ensaios hidrodinâmicos

Os resultados obtidos mostraram que até $600 \mathrm{rpm}$ o tempo de mistura diminui expressivamente com o aumento da freqüência de agitação. Os valores do intervalo obtido: de 51 s para $700 \mathrm{rpm}$ a 406 s para $200 \mathrm{rpm}$, são de ordem significativamente menor em relação aos tempos de ciclo utilizados durante a operação do reator (12 e 24 horas). É importante considerar que freqüências de agitação muito elevadas tendem a favorecer a aeração do sistema, a qual é indesejada em condições anaeróbias. Na tentativa de reduzir a difusão do oxigênio atmosférico no leito do reator, optou-se por utilizar a freqüência de agitação de 300 rpm.

\subsection{Adsorção de LAS no material suporte}

Nos ensaios de adsorção, simulou-se um ciclo de operação de 24 horas, utilizando-se solução de LAS. As concentrações utilizadas foram de 27 e 57 mg/L.

Nas Figuras 5.8 e 5.9 verifica-se que no início dos ensaios houve maior velocidade de adsorção do LAS ao meio suporte e que com o passar do tempo o sistema tendeu ao equilíbrio. Os dois ensaios demonstraram comportamento similar e após 24 horas de contato a massa de LAS adsorvida ao suporte permaneceu praticamente constante. 


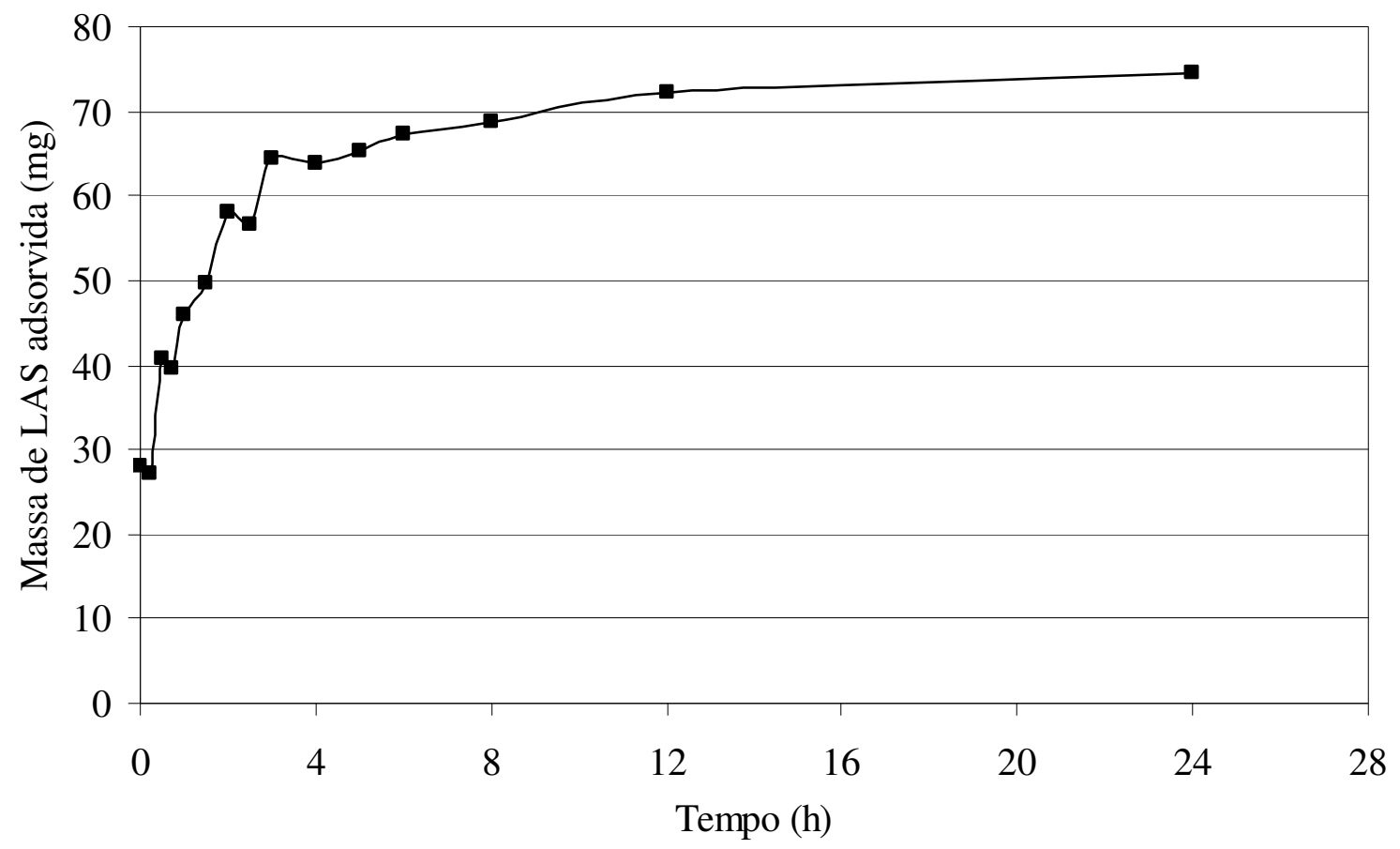

Figura 5.8 Adsorção de LAS durante o primeiro ensaio de adsorção $(27 \mathrm{mg} / \mathrm{L})$ no meio suporte em função do tempo de contato

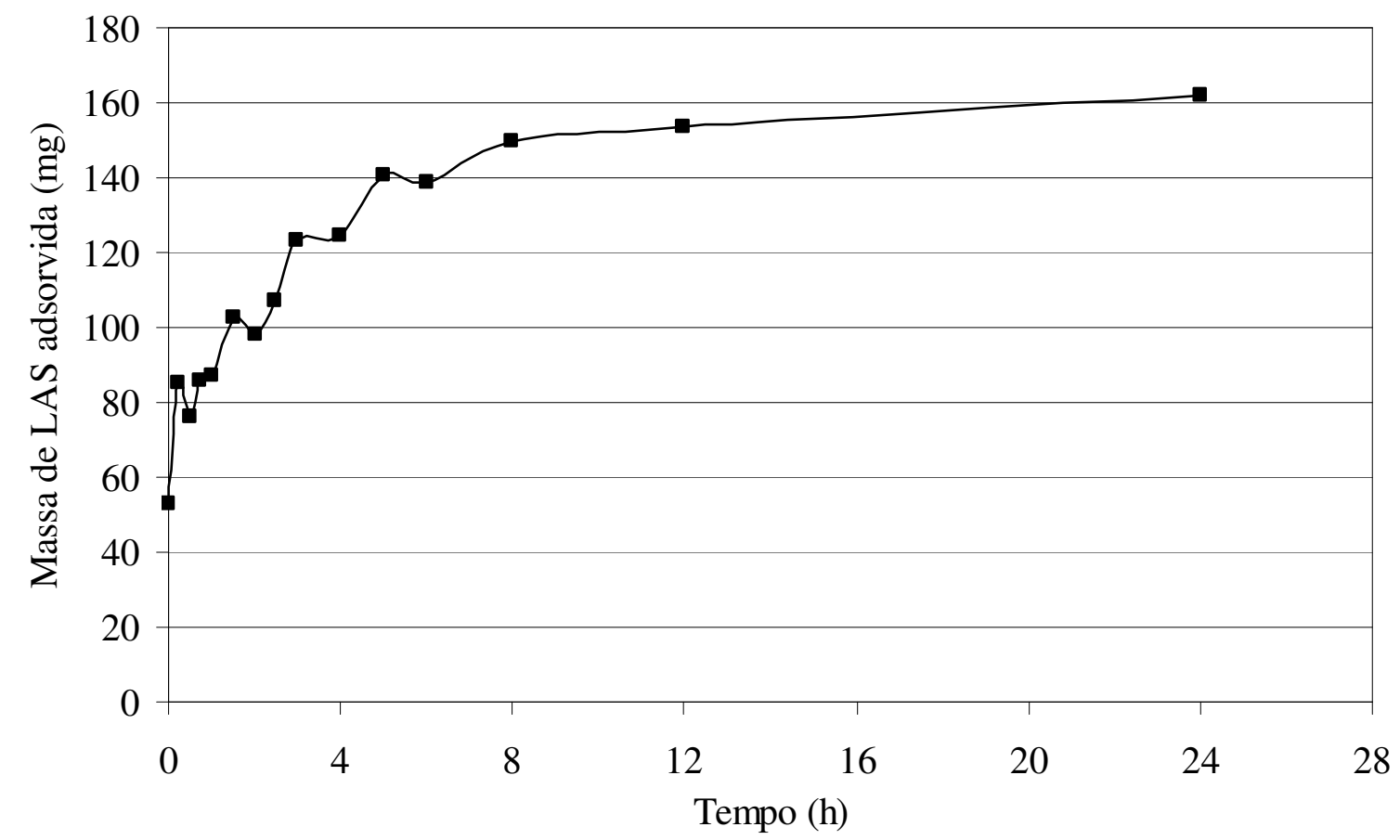

Figura 5.9 Adsorção de LAS durante o segundo ensaio de adsorção (57 mg/L) no meio suporte em função do tempo de contato

As massas de LAS adsorvidas ao meio suporte durante os ensaios foram calculadas por meio de balanço de massa. Assim, pôde-se calcular a relação entre a quantidade de LAS adsorvida por massa de material suporte (Tabelas 5.2 e 5.3). No ensaio com menor 
concentração de LAS, cerca de $75 \mathrm{mg}$ do surfactante (62\% da massa afluente) ficaram adsorvidos ao carvão, resultando em $0,12 \mathrm{mg} \mathrm{LAS}_{\mathrm{S}} / \mathrm{g}_{\text {carvão. }}$ No ensaio com LAS a $57 \mathrm{mg} / \mathrm{L}$, cerca de $162 \mathrm{mg}$ de LAS (59\% da massa afluente) ficaram adsorvidos ao carvão, resultando em 0,26 $\mathrm{mg}_{\mathrm{LAS}} / \mathrm{g}_{\text {carvão}}$.

Tabela 5.2 Balanço de massa do LAS para o primeiro ensaio de adsorção (27 mg/L)

\begin{tabular}{cc}
\hline Massa de suporte (g) & 620,1 \\
LAS afluente (mg) & 120 \\
LAS efluente (mg) & 45 \\
LAS adsorvido (mg) & 75 \\
LAS adsorvido (\%) & 62 \\
LAS (mg) / carvão (g) & 0,12 \\
\hline
\end{tabular}

Tabela 5.3 Balanço de massa do LAS para o segundo ensaio de adsorção (57 mg/L)

\begin{tabular}{cc}
\hline Massa de suporte (g) & 619,8 \\
LAS afluente (mg) & 276 \\
LAS efluente (mg) & 114 \\
LAS adsorvido (mg) & 162 \\
LAS adsorvido (\%) & 59 \\
LAS (mg) / carvão (g) & 0,26 \\
\hline
\end{tabular}

Os valores obtidos para a razão entre a massa de LAS adsorvida e massa de meio suporte foram significativamente menores do que àqueles encontrados por Oliveira (2006). Esta autora avaliou a adsorção do LAS em reator diferencial $\left(15,8 \mathrm{~cm}^{3}\right)$ com $5,71 \mathrm{mg}$ de carvão vegetal como meio suporte. A autora obteve o valor de $1,86 \mathrm{mg}_{\mathrm{LAS}} / \mathrm{g}_{\text {carvão, }}$ para concentração de LAS afluente de $13 \mathrm{mg} / \mathrm{L}$.

Esta discrepância de valores pode ser explicada pela diferença entre as escalas dos dois experimentos. Borges (2003) relata que a ampliação das escalas em pesquisas ainda é carente do entendimento de vários aspectos fundamentais do processo, como a relação entre o desempenho do sistema e as variáveis físicas e bioquímicas determinantes do processo. Possivelmente, nos ensaios de adsorção realizados no presente trabalho, o sistema não atingiu 
a saturação, já que se utilizou grande massa de adsorvente. Assim, quaisquer previsões feitas no sentido de comparar os experimentos, realizados em escalas diferentes, devem ser feitas com ressalvas.

\subsection{Balanço de massa do LAS}

Aos 256 dias de operação do sistema, amostras do material suporte foram retiradas do reator para realização da extração do LAS adsorvido no material suporte segundo metodologia descrita no item 4.9.1. Considerando o valor da massa de LAS adsorvida no material suporte e na biomassa, juntamente com o valor de sólidos totais, foi possível realizar cálculos de balanço de massa do sistema e determinar as frações de LAS removida e a degradada biologicamente.

Desse modo, observou-se que aproximadamente $16500 \mathrm{mg}$ de LAS entraram no reator, $13550 \mathrm{mg}$ foram coletados no efluente (Figura 5.10) e $340 \mathrm{mg}$ estavam adsorvidos no carvão vegetal e biomassa. Dessa maneira, pode-se verificar que houve remoção de $18 \%$, sendo que $16 \%$ de todo o LAS adicionado ao sistema, durante 256 dias, foi degradado biologicamente. 


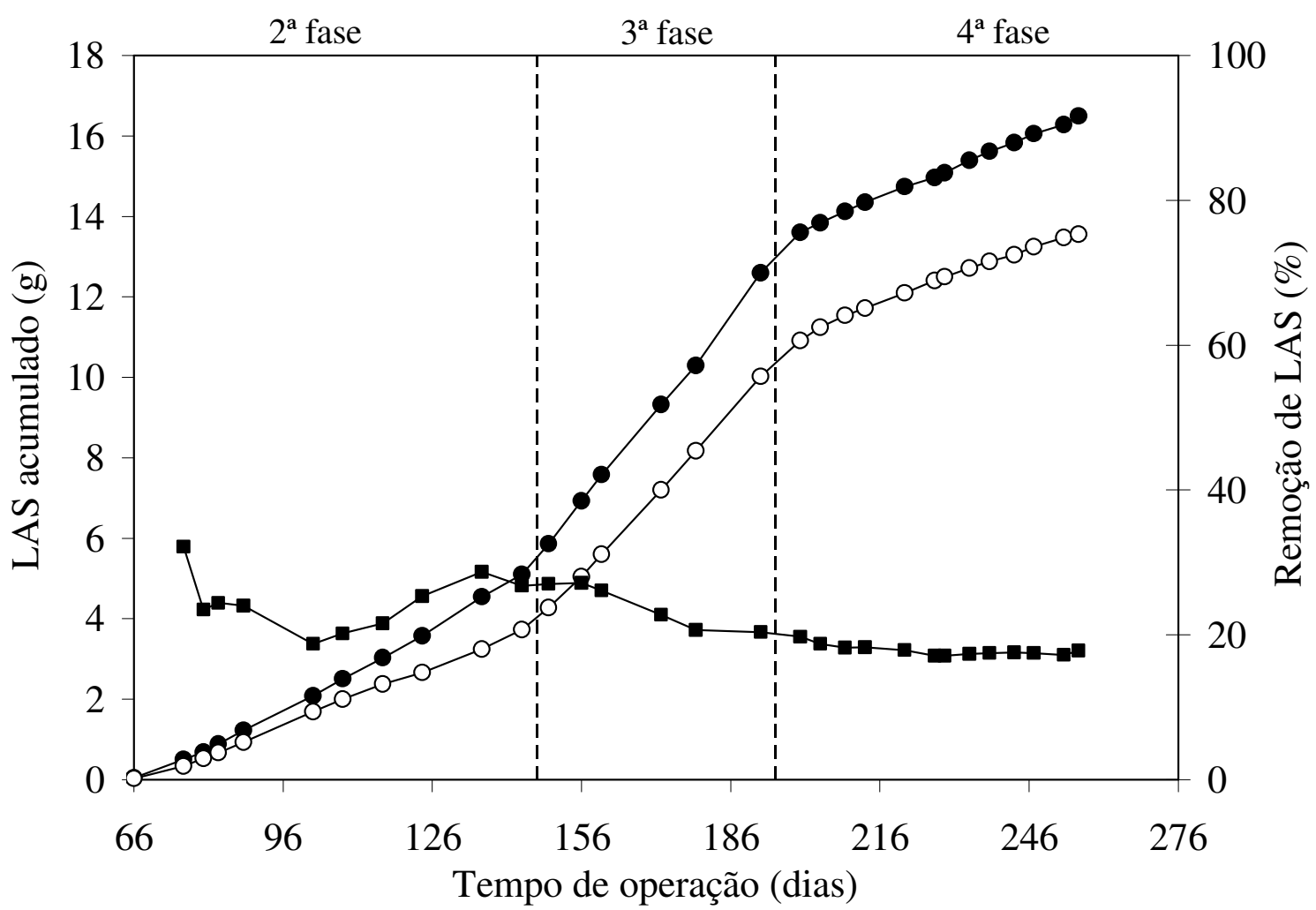

Figura 5.10 Evolução temporal da massa de LAS acumulada no afluente (•) e efluente (०) e eficiência de remoção de LAS (ロ)

Na Tabela 5.4 consta o desempenho do reator em relação à remoção e à degradação biológica do surfactante, considerando também sua adsorção ao meio suporte.

Tabela 5.4 Balanço de massa do LAS

\begin{tabular}{ccccc}
\hline $\begin{array}{c}\text { Afluente } \\
(\mathrm{g})\end{array}$ & $\begin{array}{c}\text { Efluente } \\
(\mathrm{g})\end{array}$ & $\begin{array}{c}\text { Remoção } \\
(\%)\end{array}$ & $\begin{array}{c}\text { Adsorção } \\
(\mathrm{g})\end{array}$ & $\begin{array}{c}\text { Degradação } \\
(\%)\end{array}$ \\
\hline 16,50 & 13,55 & 18 & 0,34 & 16 \\
\hline
\end{tabular}

Os valores para a degradação do LAS obtidos neste trabalho são menores em relação a outras pesquisas realizadas. Duarte (2006) obteve 35\% de remoção biológica desse surfactante utilizando reator anaeróbio horizontal de leito fixo (RAHLF), com biomassa imobilizada em espuma de poliuretano, alimentado com substrato sintético e LAS. Ainda, Oliveira (2006), obteve $28 \%$ de biodegradação também em RAHLF, utilizando leito misto de espuma de poliuretano e argila expandida. 
Duarte et al. (2007), avaliaram a degradação de LAS em ASBR de 2 L de volume útil aplicando técnicas de Biologia Molecular para avaliar a diversidade microbiana. A alimentação do sistema caracterizou as seguintes fases de operação: (1) com substrato sintético; (2) com substrato sintético acrescido de LAS a $22 \mathrm{mg} / \mathrm{L}$; (3) com substrato sintético modificado (maior concentração de extrato de levedura) e LAS a 22 mg/L; (4) com solução de LAS a 22 mg/L; e (5) sem alimentação (etapa digestão do lodo). Observou-se que o aumento da concentração de co-substratos orgânicos, sob a forma de extrato de levedura, diminuiu a degradação do LAS de $37 \%$ para $24 \%$. Inversamente, a retirada de substratos orgânicos elevou a degradação do surfactante a 53\%. A fase de digestão do lodo, com duração de 21 dias, apresentou degradação de $96 \%$.

O seqüenciamento de fragmentos do RNAr 16S de amostras coletadas do reator, após a adição de LAS na alimentação, indicou a presença de microrganismos filogeneticamente próximos a Methanosaeta sp., Methanospirilum sp. e Methanobacterium sp. Em relação ao Domínio Bacteria, foram identificados microrganismos afiliados filogeneticamente a Opitutus sp. e Arcanobacterium sp. (DUARTE et al., 2007).

Oliveira et al. (2007) operaram dois reatores anaeróbios de leito fluidificado de $0,35 \mathrm{~L}$ cada um preenchido com meios suporte distintos (carvão ativado e argila expandida) visando também a degradação de LAS. O TDH utilizado foi de 18 horas e a concentração afluente de LAS de $14 \mathrm{mg} / \mathrm{L}$. Os resultados mostraram que a eficiência de remoção de matéria orgânica não foi influenciada pelo surfactante, mantendo-se acima de $90 \%$ em todas amostras coletadas. A degradação de LAS atingiu remoção de $96 \%$ no reator com carvão ativado e $83 \%$ no sistema utilizando argila expandida.

A Tabela 5.5 resume os trabalhos previamente citados, desenvolvidos no Laboratório de Processos Biológicos (LPB) da Escola de Engenharia de São Carlos relacionados à degradação de LAS. 
Tabela 5.5 Pesquisas realizadas no Laboratório de Processos Biológicos da EESC/USP visando a degradação do LAS

\begin{tabular}{clccc}
\hline Referência & \multicolumn{1}{c}{ Tipo de reator } & $\begin{array}{c}\text { Concentração } \\
\text { afluente de } \\
\text { LAS (mg/L) }\end{array}$ & $\begin{array}{c}\text { Tempo de } \\
\text { operação } \\
\text { (dias) }\end{array}$ & $\begin{array}{c}\text { Degradação } \\
\text { de LAS } \\
(\%)\end{array}$ \\
\hline $\begin{array}{c}\text { OLIVEIRA et al. } \\
(2007)^{*}\end{array}$ & $\begin{array}{l}\text { Anaeróbio de leito } \\
\text { fluidificado }\end{array}$ & 14 & 96 & $83^{\ddagger}$ \\
$\begin{array}{c}\text { DUARTE et al. } \\
(2007)\end{array}$ & ASBR & 22 & 143 & 53 \\
$\begin{array}{c}\text { DUARTE } \\
(2006)\end{array}$ & $\begin{array}{l}\text { RAHLF com espuma } \\
\text { de poliuretano }\end{array}$ & 14 & 313 & 35 \\
$\begin{array}{c}\text { OLIVEIRA } \\
(2006)\end{array}$ & $\begin{array}{l}\text { RAHLF com carvão } \\
\text { vegetal }\end{array}$ & 14 & 343 & 28 \\
Este trabalho & $\begin{array}{l}\text { ASBBR com carvão } \\
\text { vegetal }\end{array}$ & $32^{\dagger}$ & 256 & 16 \\
\hline
\end{tabular}

${ }^{*}$ trabalho ainda em andamento

$\dagger$ maior concentração testada

$\ddagger$ dado referente à remoção de LAS

Observa-se na tabela 5.5 que os reatores de leito fixo se mostraram menos adequados ao tratamento do LAS do que os reatores de leito móvel. Tal observação é importante e deve ser levada em conta nas eventuais propostas futuras de desenhos experimentais com o intuito de degradar esse surfactante. Presume-se que o leito fixo, apesar de apresentar as vantagens anteriormente citadas em relação ao leito móvel, acaba mais por prejudicar a degradação do LAS do que auxiliá-la, já que constitui uma barreira física aos fenômenos de transferência de massa.

Considerando-se a degradação de compostos tóxicos, é geralmente assumido que o RAHLF, por seu escoamento predominantemente pistonado, pode apresentar em seu leito um gradiente de degradação constituído por diversas populações microbianas degradadoras. Assim a biodegradação do composto seria estratificada espacialmente, com as diversas populações agindo em sinergismo ao longo da extensão do reator.

Contudo, essa consideração pode ser equivocada. Gusmão (2005) avaliou desempenho de um RAHLF para tratar os hidrocarbonetos aromáticos BTEX (benzeno, tolueno, 
etilbenzeno e xilenos). Utilizando técnicas de Biologia Molecular (DGGE), a autora observou o mesmo padrão de bandas para as diferentes relações comprimento/diâmetro (L/D) amostradas sob todas as condições de alimentação testadas. Todavia, embora com a mesma distribuição de populações, a autora, também verificou diminuição na concentração de biomassa ao longo do reator.

Apesar de apresentarem flexibilidade de operação, os reatores descontínuos, nos quais as populações de microrganismos estão expostas às mesmas concentrações de substrato, podem ter sua eficiência de degradação reduzida no caso do tratamento de poluentes, já que se permite a possibilidade do composto tóxico agir de maneira uniforme sobre toda a biomassa do reator. Diferentemente do RAHLF, não se cria um gradiente de concentração de substrato.

Associado a questão anteriormente levantada, considera-se que o reator utilizado no presente trabalho apresentou valores menores de degradação de LAS em relação aos outros trabalhos mostrados na Tabela 5.5 possivelmente devido à colmatação do meio, evidenciada pela formação excessiva de polímeros extracelulares observados na desmontagem do sistema. A presença desses exopolímeros possivelmente acabou por comprometer a hidrodinâmica do ASBBR durante as últimas fases de operação.

Miqueleto (2006) afirma que apesar do ASBBR ter mostrado resultados positivos, alguns trabalhos relatam que, sob determinadas condições, ocorre produção elevada de material polimérico viscoso, cuja conseqüência é a redução nas velocidades de transferência de massa (RATUSZNEI et al., 2003, BORGES et al, 2004, ORRA et al., 2004, SIMAN et al., 2004, MIQUELETO et al., 2005). Essa diminuição tem sido considerada como responsável pela queda na eficiência de remoção da matéria orgânica.

Com o intuito de se evitar os problemas anteriormente citados, Oliveira et al. (2007) propôs o tratamento de LAS utilizando reator anaeróbio de leito fluidificado (apresentado na Tabela 5.5). A pesquisa encontra-se em andamento e os resultados parciais mostram excelente prognóstico para essa configuração na biodegradação do LAS, uma vez que consegue ao 
mesmo tempo evitar a redução na transferência de massa e ainda manter boa concentração de biomassa dentro do reator.

\subsection{Análises de monitoramento}

\subsubsection{Potencial Hidrogeniônico}

Durante toda a operação do reator, o pH das bateladas manteve-se levemente alcalino, tanto para o substrato afluente quanto para o efluente do reator. A Tabela 5.6 apresenta os valores mínimos e máximos de $\mathrm{pH}$ observados nas fases de operação do reator. Nota-se que durante toda a operação os valores de $\mathrm{pH}$ mantiveram-se dentro da faixa ótima para metanogênese, que é de 6,0 a 8,0 (CHERNICHARO, 1997). Portanto, considera-se que a quantidade de bicarbonato de sódio adicionada à alimentação foi suficiente em prover o tamponamento necessário.

Tabela 5.6 Valores de pH máximos e mínimos observados durante o monitoramento

\begin{tabular}{ccccccccc}
\hline & \multicolumn{2}{c}{$1^{\text {a }}$ fase } & \multicolumn{2}{c}{$2^{\text {a }}$ fase } & \multicolumn{2}{c}{$3^{\text {a }}$ fase } & \multicolumn{2}{c}{$4^{\text {a }}$ fase } \\
\cline { 2 - 8 } & Máx. & Mín. & Máx. & Mín. & Máx. & Mín. & Máx. & Mín. \\
\hline Afluente & 7,65 & 6,96 & 7,70 & 7,08 & 7,80 & 7,31 & 7,79 & 7,23 \\
Efluente & 7,60 & 7,07 & 7,62 & 7,14 & 7,74 & 7,11 & 7,64 & 7,44 \\
\hline
\end{tabular}

A Figura 5.11 apresenta os valores médios de $\mathrm{pH}$ observados. Alterações significativas desse parâmetro não foram observadas ao longo da operação do sistema. A maior diferença entre o pH afluente e efluente ocorreu na terceira fase de operação, na qual houve redução da alcalinidade gerada (item 5.4.3) associada ao aumento da concentração de ácidos voláteis (item 5.4.5). Os valores médios de $\mathrm{pH}$ para o afluente e efluente dessa etapa foram de $7,58 \pm 0,15$ e $7,41 \pm 0,19$, respectivamente. 


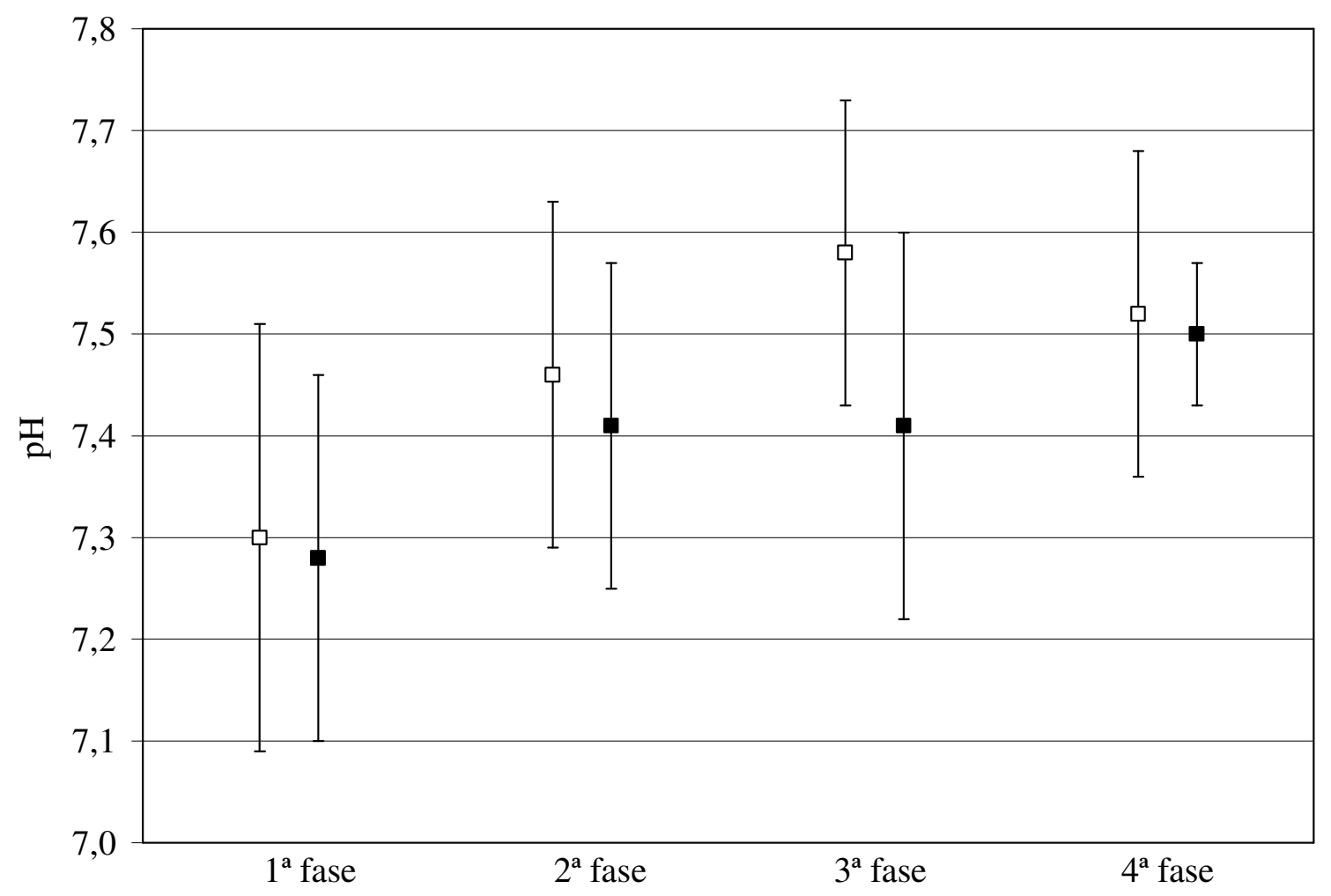

Figura 5.11 pH médio afluente ( $\square$ ) e efluente (ロ) nas fases de operação

\subsubsection{Remoção de matéria orgânica}

A Figura 5.12 mostra a variação da DQO afluente e efluente ao longo da operação.

Nessa figura pode-se observar que durante a primeira e segunda etapa a DQO efluente manteve-se constante, apesar de apresentar valores distintos. Quando LAS foi adicionado na alimentação a $32 \mathrm{mg} / \mathrm{L}$, durante a terceira fase, observou-se considerável elevação na DQO efluente nesse período. 


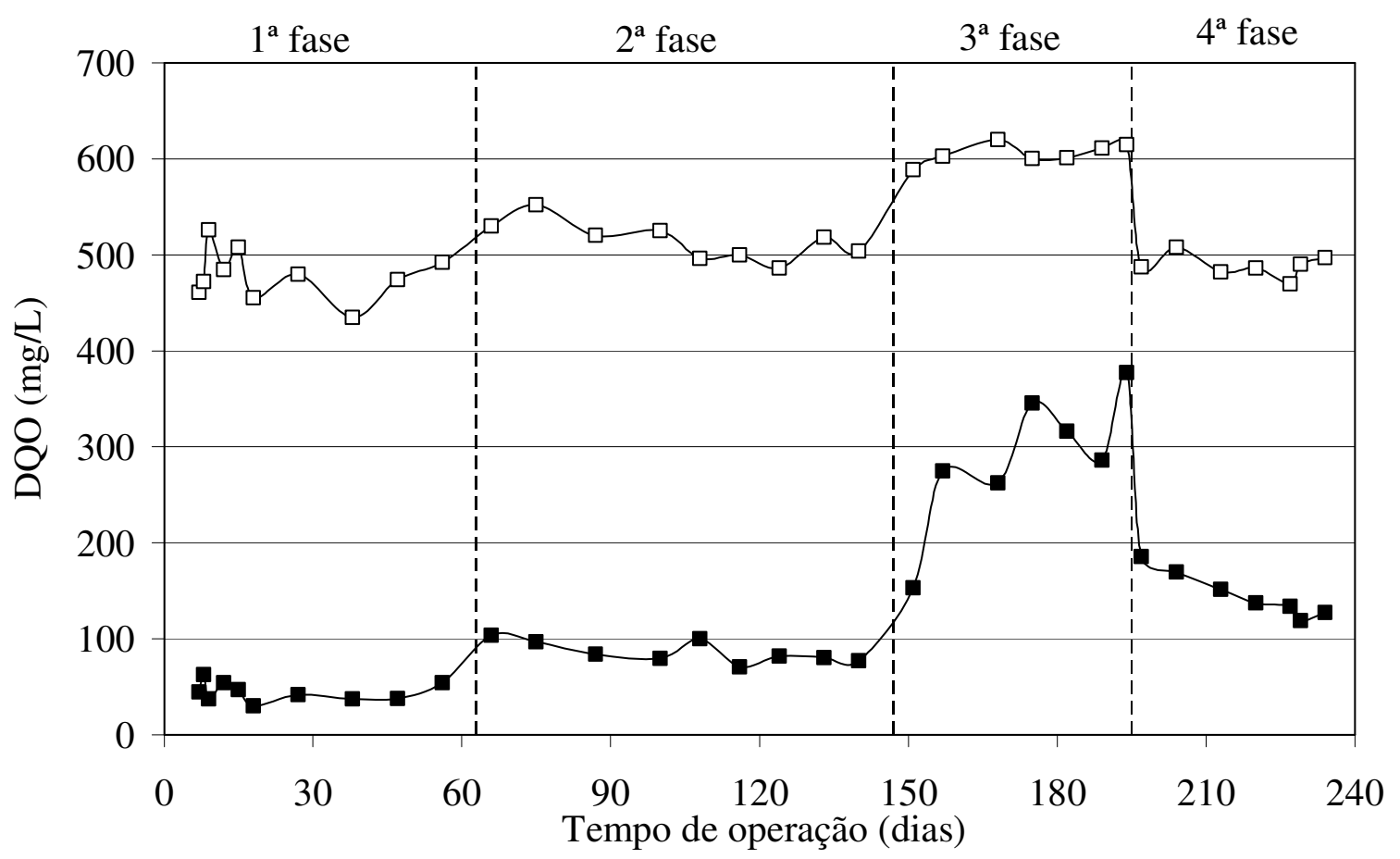

Figura 5.12 Variação temporal da DQO afluente ( $\square$ ) e efluente (ロ) do reator

Na Figura 5.13 são apresentados os valores médios de DQO afluente e efluente amostrados. Observou-se maior variação na DQO efluente durante a terceira etapa. A média observada no efluente durante essa etapa foi de $288 \pm 72 \mathrm{mg} / \mathrm{L}$. Essa variação se deve à desestabilização do sistema observada quando foi aumentada a concentração de LAS na alimentação. 


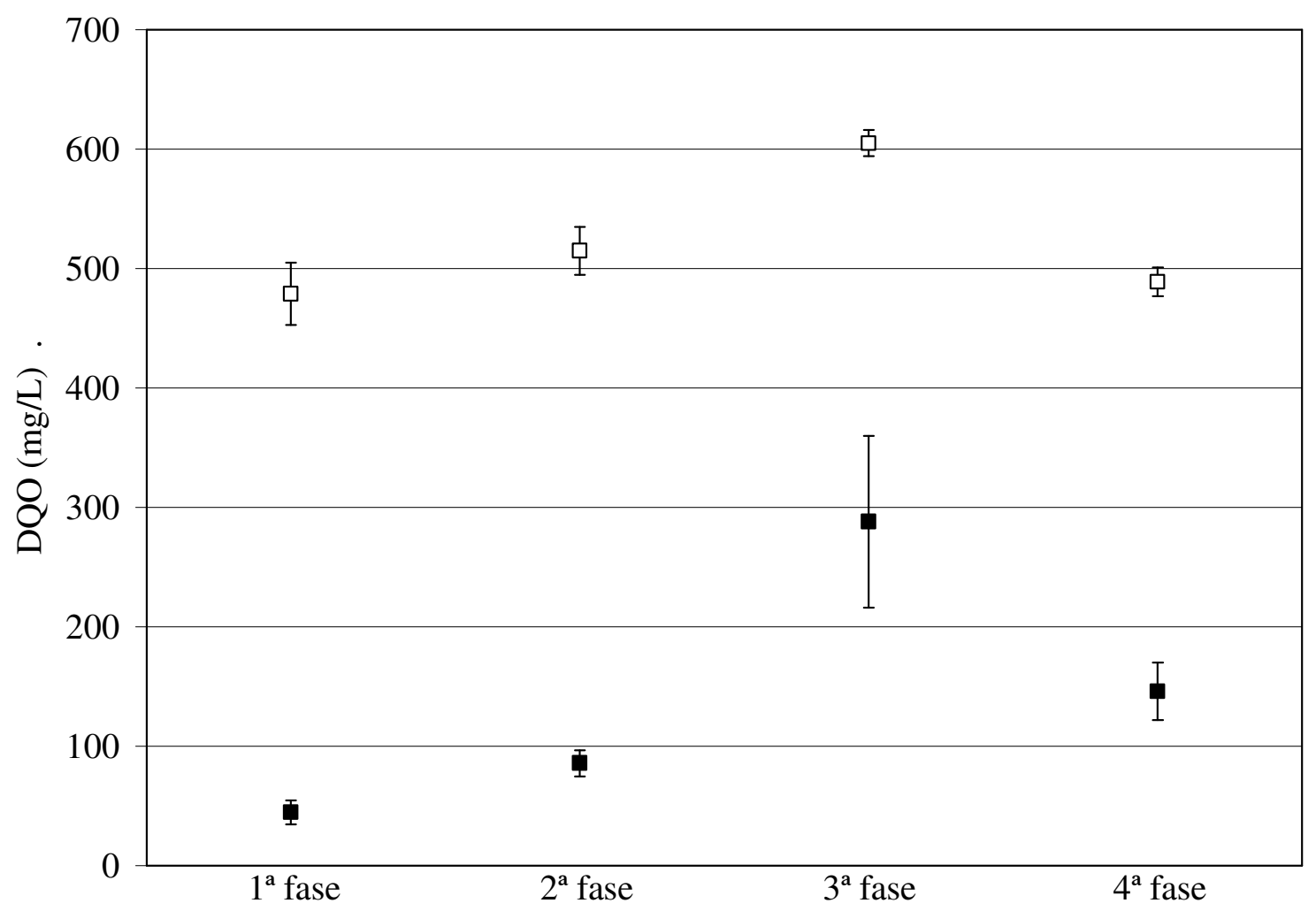

Figura 5.13 DQO média afluente ( $\square$ ) e efluente ( $\square$ ) em cada etapa de operação

Na Figura 5.14 estão mostradas as eficiências de remoção de DQO. Durante a primeira etapa o reator foi alimentado somente com substrato sintético, que é de fácil degradação. Nessa etapa, a eficiência de remoção de DQO foi de $91 \% \pm 2$ p.p. Durante a segunda etapa de operação, na qual o LAS foi adicionado à alimentação, essa eficiência diminuiu para $83 \% \pm 2$ p.p. Apesar dessa redução, a operação do reator continuou a demonstrar estabilidade. Na terceira etapa de operação, na qual o reator foi alimentado com a maior concentração de LAS testada (32 mg/L), a eficiência média de remoção de matéria orgânica atingiu o mínimo valor observado, $53 \% \pm 2$ p.p. 


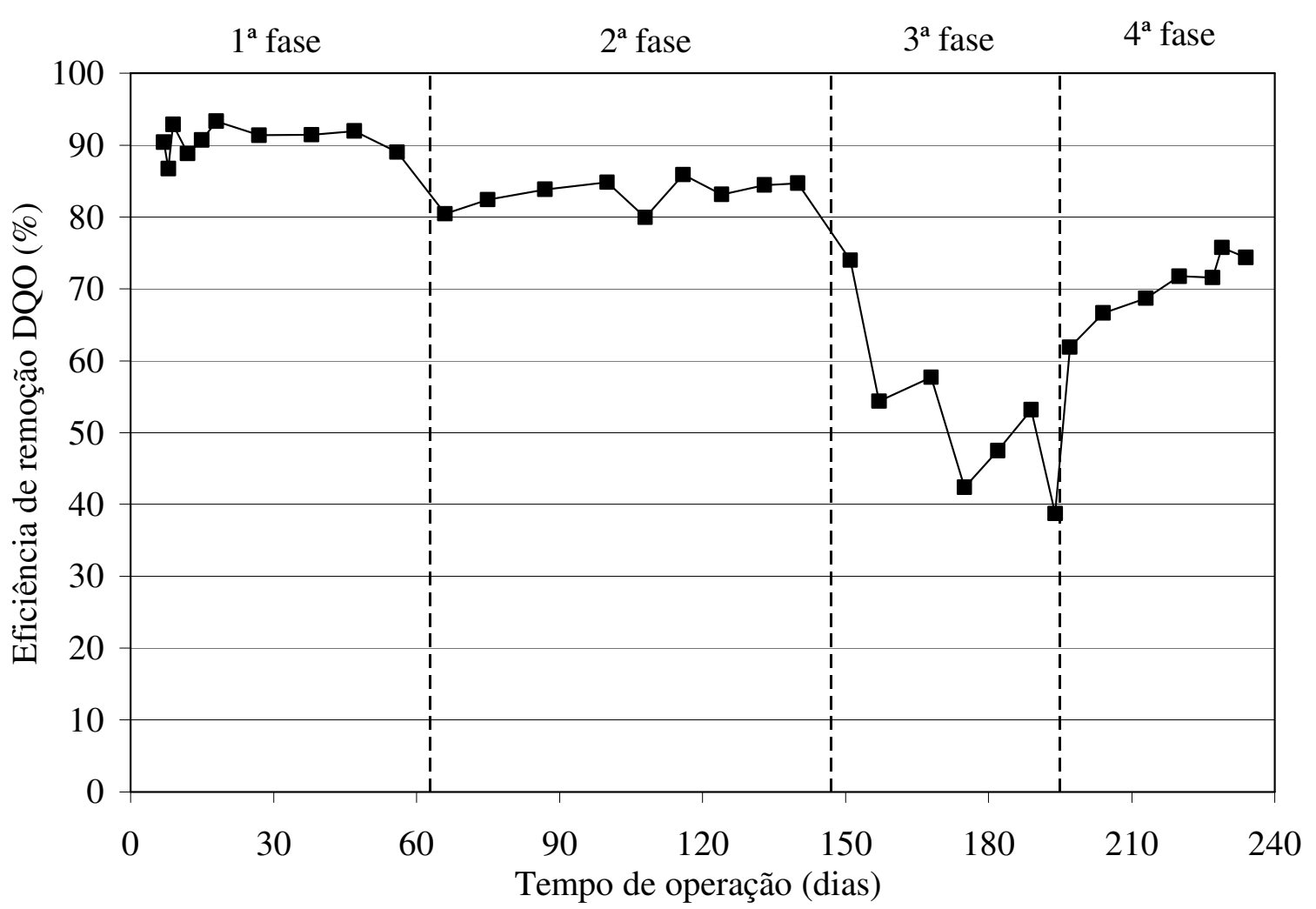

Figura 5.14 Variação temporal da eficiência de remoção de DQO no reator

Devido ao inadequado comportamento observado na remoção de DQO no reator, retirou-se a sacarose da composição do substrato e diminuiu-se a concentração de LAS, com o intuito de melhorar o desempenho do sistema. Como citado anteriormente, a biodegradação de LAS é favorecida quando a concentração de co-substratos orgânicos é reduzida (SANZ et al., 2003). Assim, a concentração de LAS foi reduzida a $10 \mathrm{mg} / \mathrm{L}$ durante a quarta etapa. Observou-se melhora na remoção de DQO. A eficiência média para esse período elevou-se para $70 \% \pm 5$ p.p.

Dessa maneira, os valores observados durante o monitoramento permitem concluir que o sistema foi sensível à concentração do LAS e este influenciou negativamente a remoção de matéria orgânica. Os dados obtidos são corroborados pela literatura. Segundo Manousaki et al. (2004), concentrações de LAS entre 20 e $50 \mathrm{mg} / \mathrm{L}$ podem restringir as vias de sua degradação e concentrações maiores podem ainda ter efeito inibitório total em sistemas anaeróbios de tratamento. 


\subsubsection{Alcalinidade a bicarbonato}

A Figura 5.15 mostra a variação da alcalinidade a bicarbonato. Durante a primeira etapa esse parâmetro apresentou média de $399 \pm 26 \mathrm{mgCaCO}_{3} / \mathrm{L}$; na segunda etapa, de $359 \pm 14 \mathrm{mgCaCO}_{3} / \mathrm{L}$. Da mesma maneira como a remoção de matéria orgânica, a alcalinidade a bicarbonato gerada pelo sistema se comportou conforme a concentração de LAS afluente. Durante a terceira etapa esse parâmetro apresentou valor mínimo de $241 \mathrm{mgCaCO}_{3} / \mathrm{L}$, enquanto o valor médio foi de $297 \pm 47 \mathrm{mgCaCO}_{3} / \mathrm{L}$. Na etapa posterior, obteve-se melhora, atingindo-se a média de $353 \pm 37 \mathrm{mgCaCO}_{3} / \mathrm{L}$.

Com exceção da terceira etapa, os resultados obtidos foram próximos aos relatados por Oliveira (2006). Esta autora obteve valor de alcalinidade a bicarbonato de $350 \mathrm{mgCaCO} / \mathrm{L}$ para condições de alimentação similares às utilizadas durante a segunda etapa do presente trabalho, as quais foram de $359 \mathrm{mgCaCO}_{3} / \mathrm{L}$. De qualquer forma, qualquer comparação mais profunda deve ser feita com ressalvas já que as configurações experimentais utilizadas nos dois trabalhos foram distintas.

\subsubsection{Alcalinidade total e parcial}

O sistema foi capaz de gerar alcalinidade (Figura 5.16). Observa-se que a alcalinidade total efluente comportou-se conforme a alcalinidade a bicarbonato, apresentando redução durante a terceira fase de operação. Neste período este parâmetro chegou ao valor mínimo de $308 \mathrm{mgCaCO}_{3} / \mathrm{L}$ e apresentou média de $350 \pm 30 \mathrm{mgCaCO}_{3} / \mathrm{L}$. Entretanto, a alcalinidade parcial efluente não sofreu diminuição com o aumento da concentração de LAS e manteve-se em média, a $127 \pm 6 \mathrm{mgCaCO}_{3} / \mathrm{L}$. 


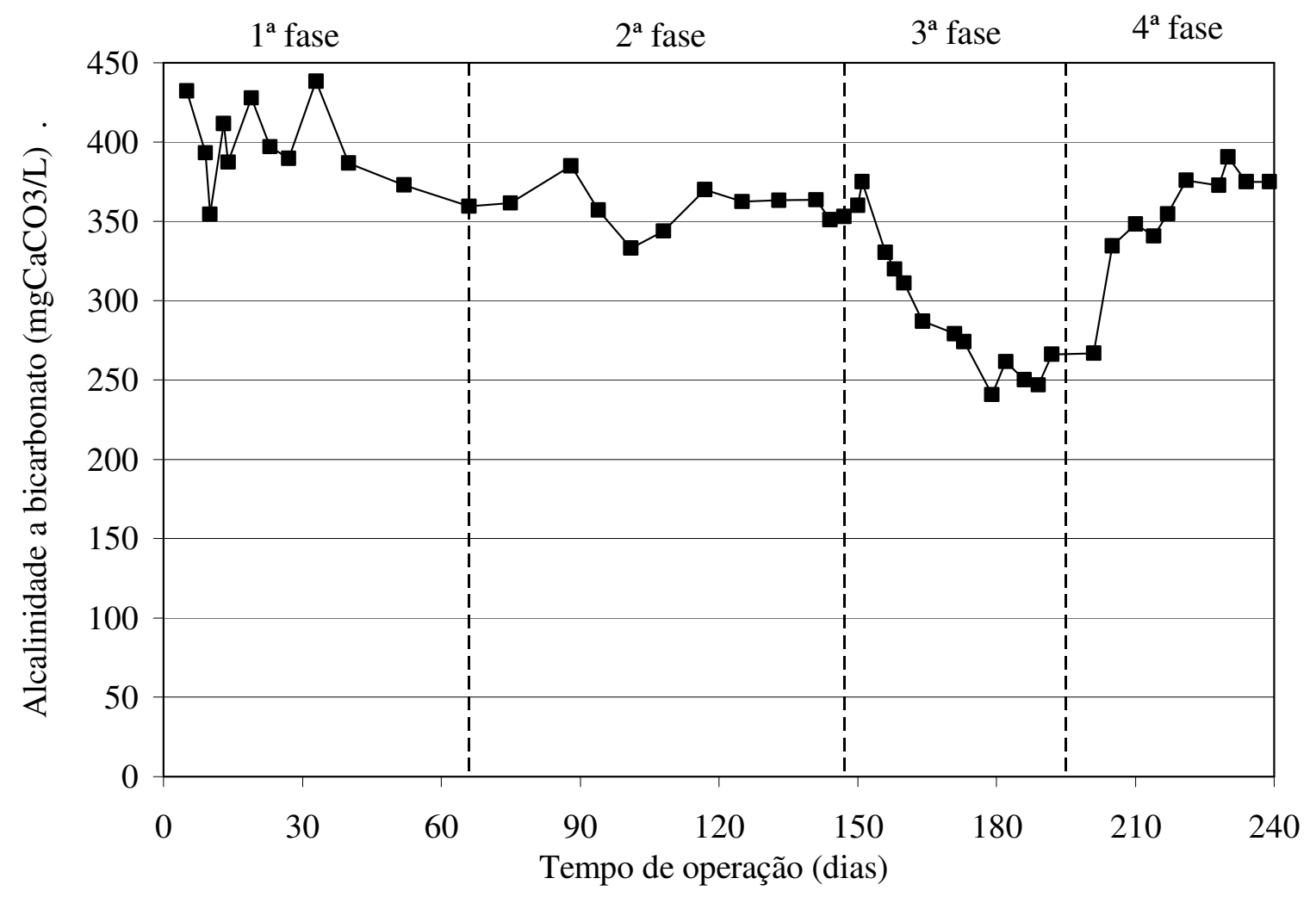

Figura 5.15 Variação temporal da alcalinidade a bicarbonato no reator

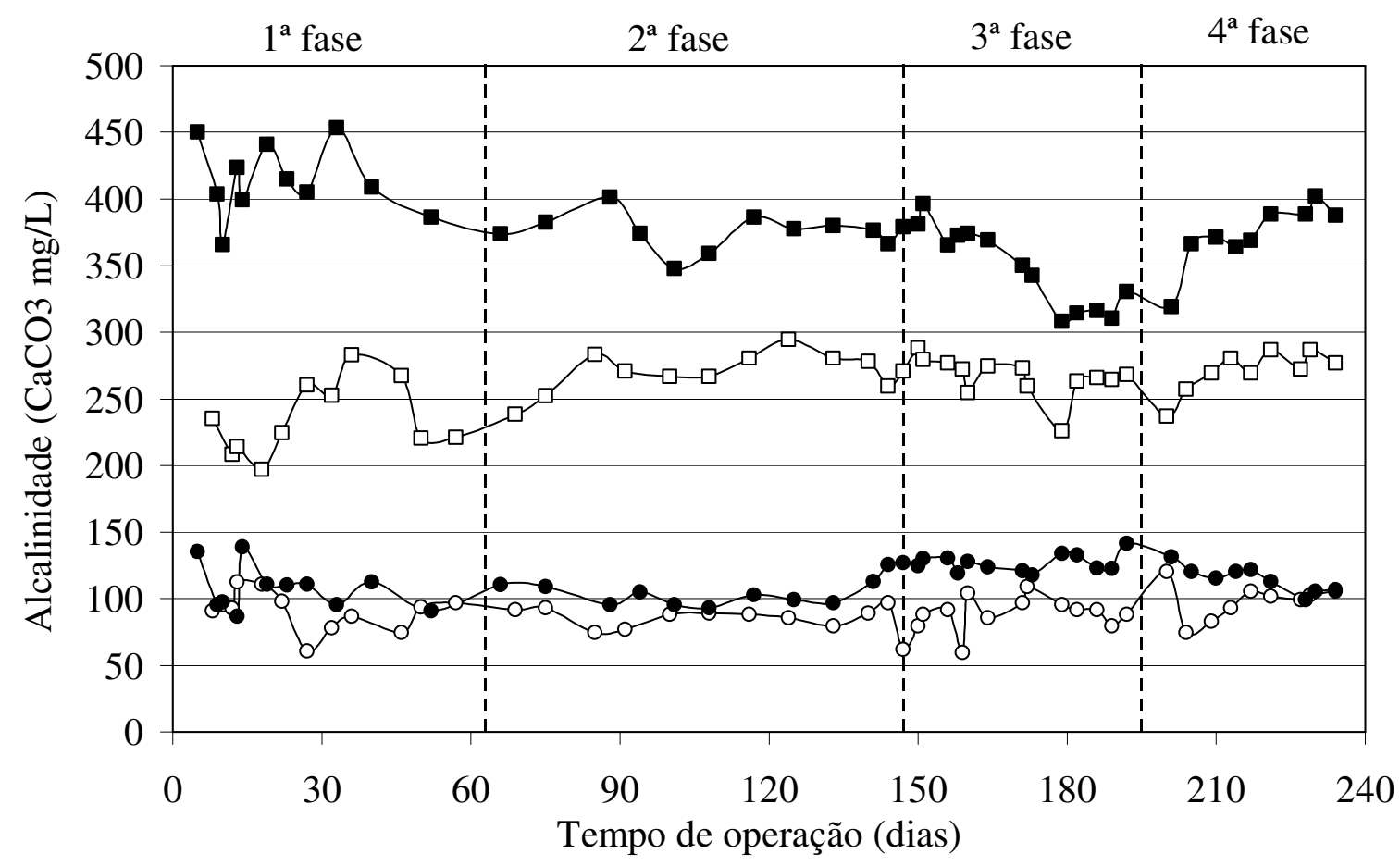

Figura 5.16 Variação temporal da alcalinidade parcial afluente (०) e efluente (•) e alcalinidade total afluente ( $\square$ ) e efluente ( $\square$ ) do reator 


\subsection{5 Ácidos voláteis totais}

A Figura 5.17 mostra as concentrações de ácidos voláteis efluente do reator. Observou-se que durante a primeira e a segunda etapas, a concentração desses ácidos orgânicos manteve-se praticamente constante, em $21 \pm 5$ e $22 \pm 3 \mathrm{mgHac} / \mathrm{L}$, respectivamente. Contudo, na terceira etapa de operação ocorreu aumento considerável dessa concentração. O valor máximo e médio obtido para esse período foram de 97 e $68 \pm 24 \mathrm{mgHAc} / \mathrm{L}$, respectivamente.

O aumento observado da concentração de ácidos voláteis pode ser considerado responsável pelo consumo de alcalinidade apresentado nos itens anteriores. Conjuntamente com os outros parâmetros físico-químicos analisados, esse acúmulo de ácidos voláteis totais reforça o quadro de desequilíbrio do reator durante a terceira etapa.

Durante a quarta etapa, a concentração desses ácidos mostrou redução e, depois de 22 dias, voltou aos valores anteriormente encontrados na primeira e segunda etapa. $\mathrm{O}$ valor médio para a última fase de operação foi de $31 \pm 19 \mathrm{mgHAc} / \mathrm{L}$.

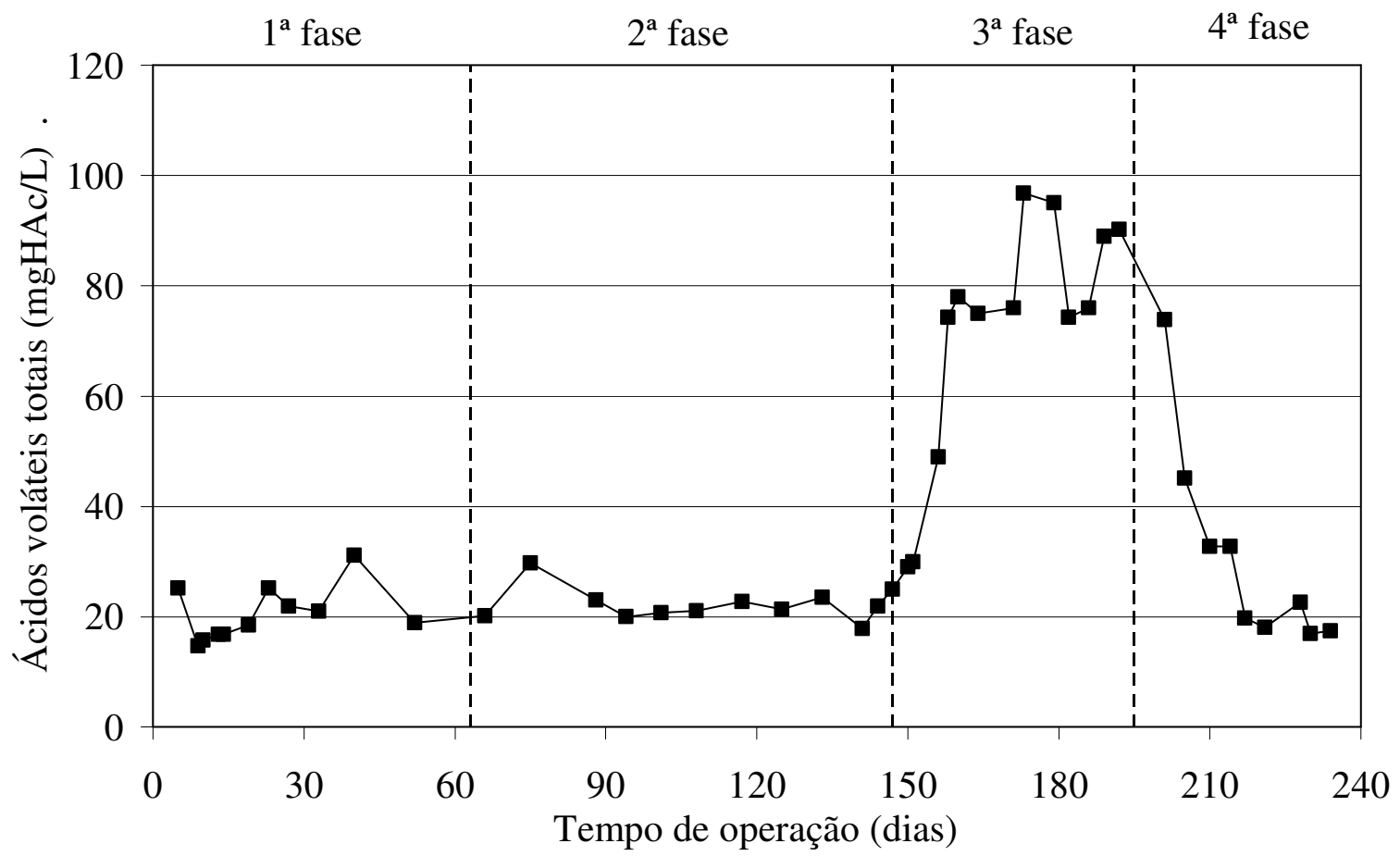

Figura 5.17 Variação temporal de ácidos voláteis totais no reator 


\subsection{Análise da diversidade microbiana}

Neste trabalho, a diversidade microbiana foi monitorada por exames microscópicos e técnicas de Biologia Molecular (PCR/DGGE) de amostras do biofilme provenientes do reator retirada ao final da operação.

\subsubsection{Caracterização do inóculo}

Como citado anteriormente, lodo anaeróbio proveniente de reator UASB, utilizado no tratamento de águas residuárias de suinocultura foi utilizado como inóculo. Esse lodo apresentou valores médios de 20,4 g/L de sólidos totais, $16,8 \mathrm{~g} / \mathrm{L}$ de sólidos totais voláteis e 3,6 g/L de sólidos totais fixos. Os valores obtidos foram menores em relação ao usualmente encontrado nesse lodo. Oliveira (2006) obteve os seguintes valores: 72 g/L de sólidos totais, 51,9 g/L de sólidos totais voláteis e 20,1 g/L de sólidos totais fixos para lodo coletado do mesmo reator em período diferente.

A redução dos valores de sólidos observados no presente trabalho foi relacionada possivelmente ao fato de que, no momento da coleta, o reator não estava em funcionamento havia 3 meses. Sob essas condições, é provável que a comunidade bacteriana presente no reator estivesse sob estado de endogenia, sem crescimento celular devido a carência nutricional.

Entretanto, os exames microscópicos do inóculo não mostraram alteração na diversidade de morfologias microbianas encontradas. Foram visualizados Methanosaeta sp., bacilos retos, curvos, cocos e sarcianas (Figura 5.18). 


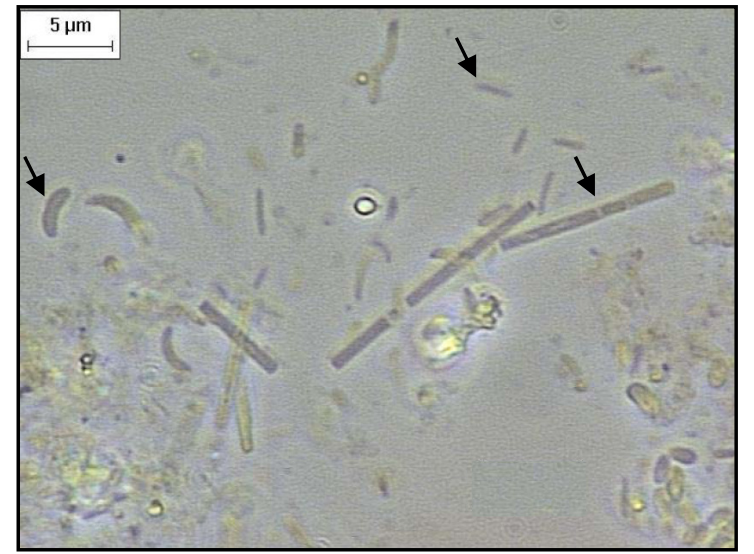

(a)

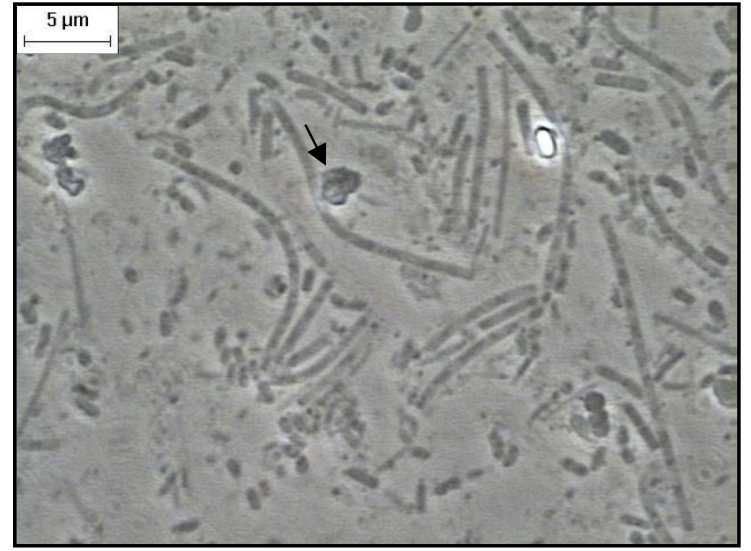

(b)

Figura 5.18 Microscopia de contraste de fase de morfologias microbianas presentes no inóculo: (a) Methanosaeta sp. e bacilos retos e curvos; (b) sarcina

\subsubsection{Caracterização das amostras do reator}

Os exames microbiológicos realizados com amostras retiradas durante a primeira etapa de operação (após 57 dias de operação) revelaram a existência de elevada diversidade morfológica de microrganismos (Figura 5.19 e Tabela 5.7) com predomínio de bacilos curvos. Alterações significativas não foram observadas entre as morfologias do inóculo (Figura 5.18) e as provenientes do reator (Figura 5.19 a 5.22 e Tabela 5.7).

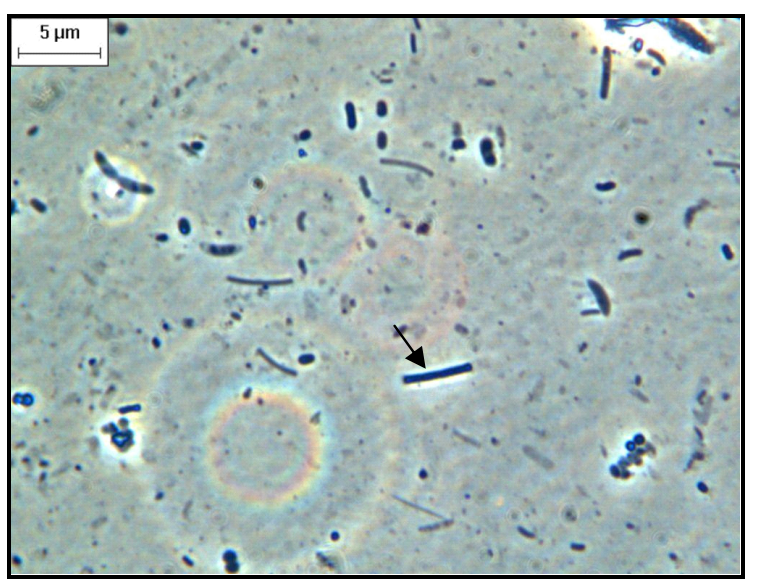

(a)

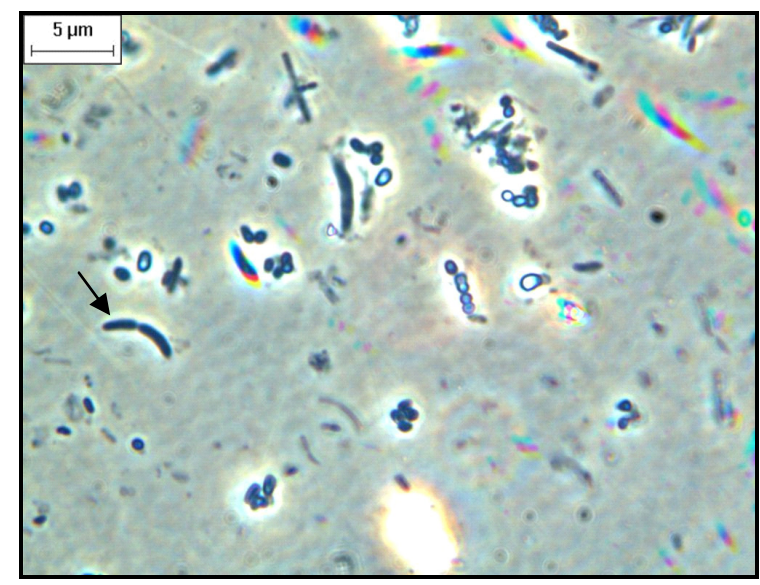

(b)

Figura 5.19 Microscopia de contraste de fase de morfologias microbianas presentes no reator durante a primeira etapa de operação: (a) bacilo, (b) bacilos curvos 


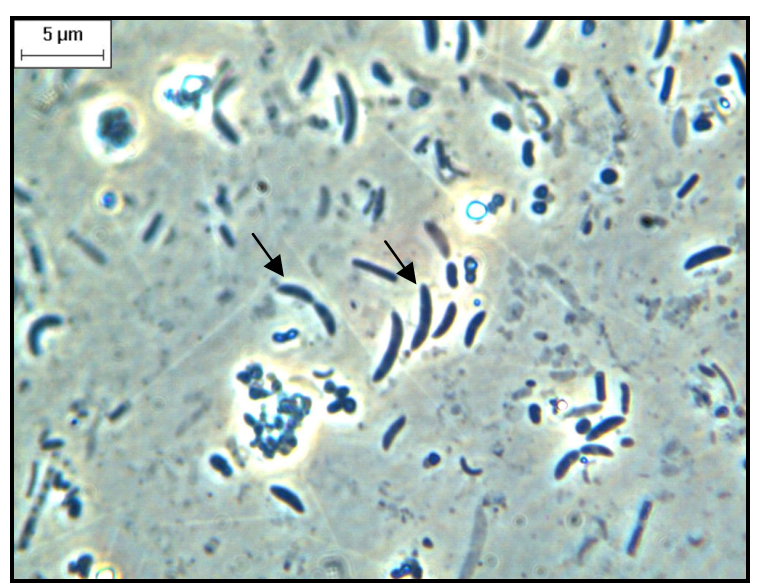

(a)

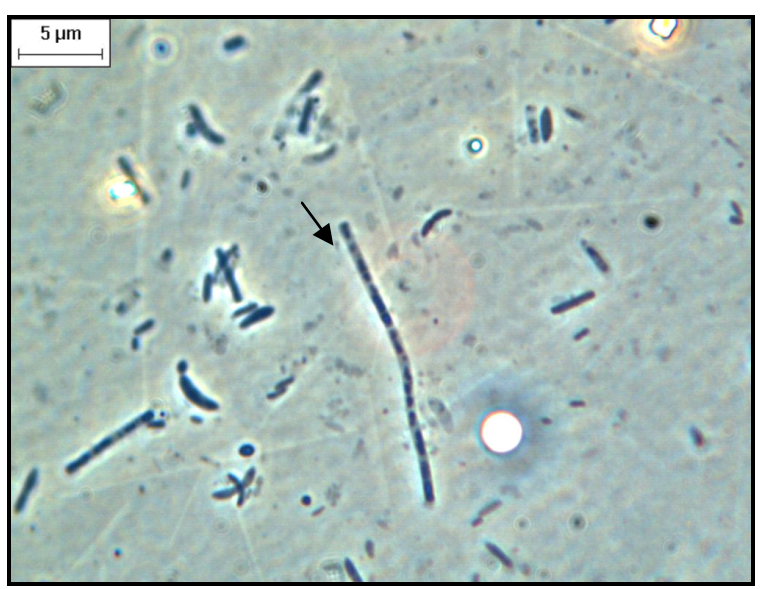

(b)

Figura 5.20 Microscopia de contraste de fase de morfologias microbianas presentes no reator durante a segunda etapa de operação: (a) bacilos curvos, (b) Methanosaeta sp.

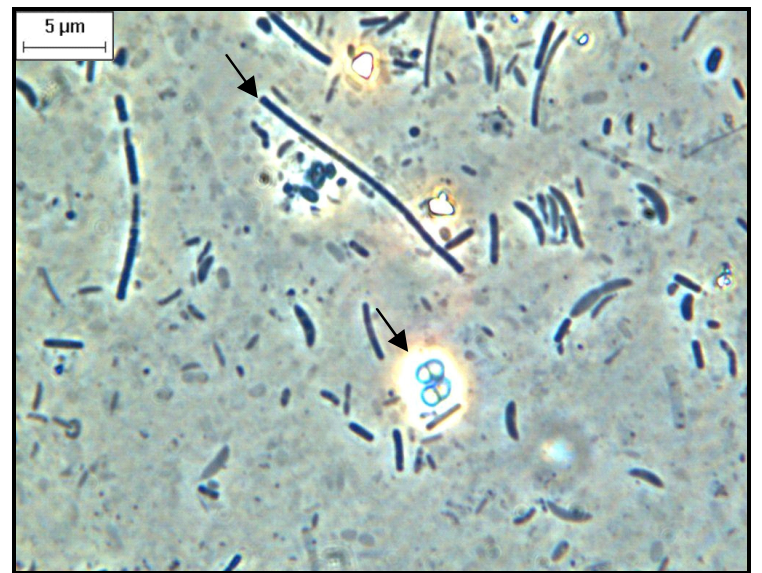

(a)

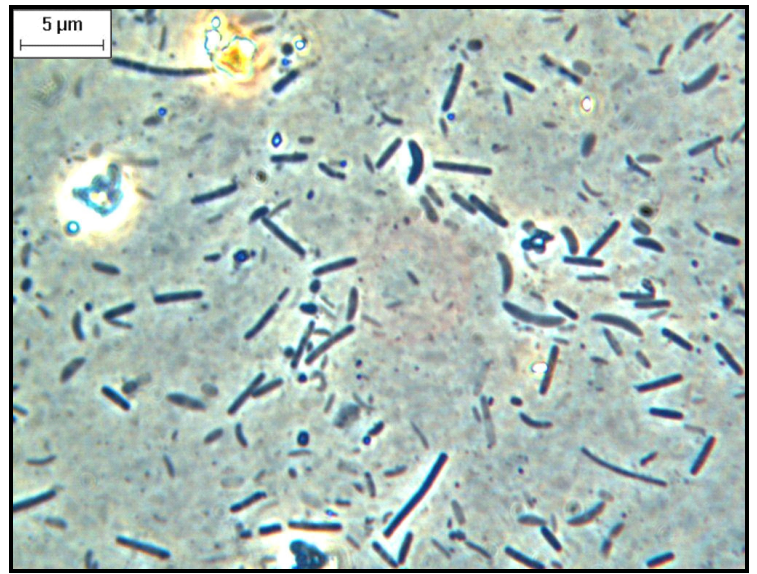

(b)

Figura 5.21 Microscopia de contraste de fase de morfologias presentes no reator durante a terceira etapa de operação: (a) Methanosaeta sp. e sarcina (b) bacilos

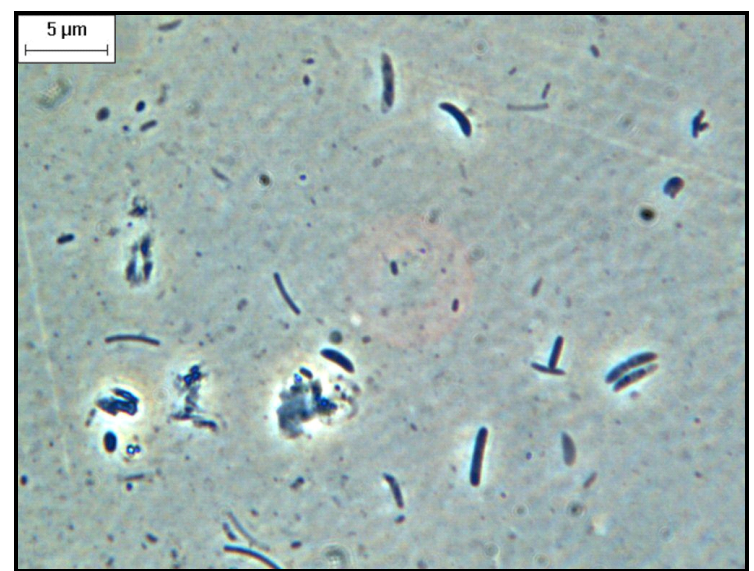

(a)

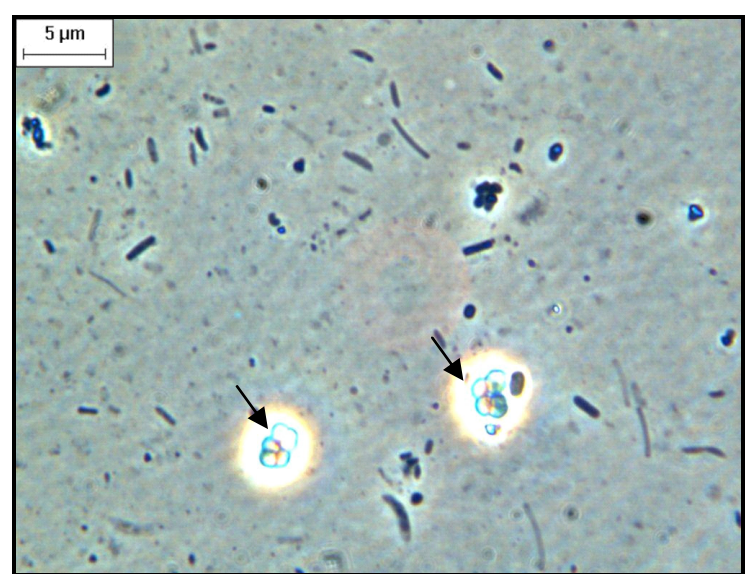

(b)

Figura 5.22 Microscopia de contraste de fase de morfologias presentes no reator durante a quarta etapa de operação: (a) bacilos, (b) sarcinas 
Tabela 5.7 Caracterização morfológica microbiana do reator

\begin{tabular}{|c|c|c|c|c|c|}
\hline \multirow{3}{*}{ Morfologias } & \multicolumn{5}{|c|}{ FREQÜÊNCIA } \\
\hline & \multirow[b]{2}{*}{ Inóculo } & \multicolumn{4}{|c|}{ Etapas de operação } \\
\hline & & I & II & III & IV \\
\hline \multicolumn{6}{|l|}{ BACTÉRIAS } \\
\hline Bacilos retos & +++ & ++ & ++ & +++ & +++ \\
\hline Bacilos curvos & ++ & +++ & ++++ & +++ & +++ \\
\hline Bacilos ovalados & + & ++ & ++ & - & + \\
\hline Filamentos & +++ & + & - & ++ & + \\
\hline Sarcinas & + & ++ & - & ++ & + \\
\hline \multicolumn{6}{|c|}{ ARQUÉIAS METANOGÊNICAS } \\
\hline Methanosaeta sp. & +++ & ++ & ++ & + & ++ \\
\hline
\end{tabular}

$(++++)$ predominantes; $(+++)$ freqüentes; $(++)$ pouco freqüentes;

$(+)$ raros; (-) não foram observados.

Com as análises de microscopia óptica, pôde-se constatar que não ocorreu diferença significativa em relação às morfologias microbianas presentes no reator durante todo o período de operação. As morfologias presentes no inóculo se mantiveram em todas as etapas, apesar das variações nas condições de alimentação.

\subsubsection{Técnicas de Biologia Molecular}

As técnicas de Biologia Molecular (PCR/DGGE) foram aplicadas a amostras retiradas do inóculo e do reator ao final da operação. Essas técnicas complementaram os exames microscópicos uma vez que permitiram visualizar a presença de determinadas populações presentes nas amostras. Assim foi possível traçar um panorama geral sobre a estrutura da comunidade microbiana em dois momentos distintos, ou seja, do inóculo e depois do contato com o LAS.

A Figura 5.23 apresenta as bandas padrões observadas no gel de DGGE. Nota-se que a maioria das populações presentes no inóculo não permaneceram até o fim da operação do 
reator. Dessa maneira, pode-se considerar que o meio suporte foi seletivo, ou seja, somente algumas populações bacterianas conseguiram colonizar a matriz do carvão. Tais populações conseguiram se estabelecer no biofilme e, provavelmente foram as responsáveis pela degradação do LAS afluente ao reator.

Duarte (2008) utilizou espuma de poliuretano como meio suporte de RAHLF no tratamento de LAS. A autora observou que três bandas das quatro visualizadas referentes ao Domínio Bacteria mantiveram-se desde o inóculo até o fim da operação do reator, enquanto que as bandas de arquéias sofreram redução ao longo da operação. Almendariz et al. (2001) operando sistema anaeróbio em dois estágios (acidogênico e metanogênico) visando a biodegradação de LAS, observou que as bactérias acidogênicas foram majoritariamente responsáveis pela degradação do surfactante. As arquéias metanogênicas se mostraram sensíveis ao LAS, cujo acúmulo no compartimento metanogênico causou inibição da produção de metano.

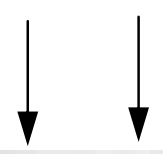

(a)

(b)

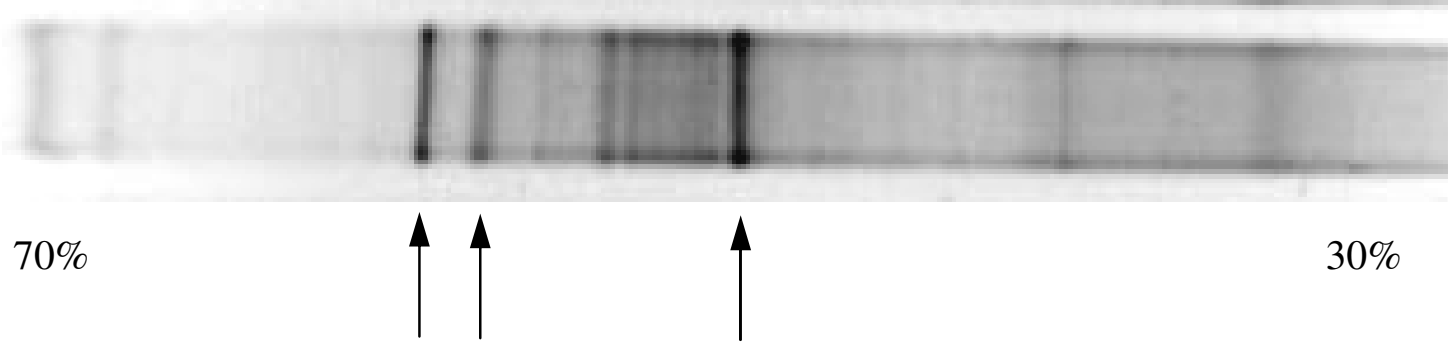

Figura 5.23 Perfil das bandas de DGGE para o Domínio Bacteria de amostras do (a) inóculo e (b) carvão vegetal ao final de 256 dias de operação (gradiente de 30\% a 70\%) 



\section{CONCLUSÕES}

- A hidrodinâmica do reator, com o meio suporte livre de biomassa, mostrou-se eficiente, mesmo com baixas freqüências de agitação.

- Independente da concentração de LAS afluente, a adsorção do surfactante ao meio suporte exibiu o comportamento semelhante, em termos de velocidade de saturação.

- O aumento da concentração de LAS influenciou negativamente a remoção de matéria orgânica. Na maior concentração de LAS testada, obteve-se a menor eficiência de remoção de DQO.

- Nas condições testadas, a concentração afluente de LAS de $32 \mathrm{mg} / \mathrm{L}$ mostrou ser tóxica aos microrganismos.

- O sistema não foi adequado para a degradação de LAS nas condições testadas, já que outros trabalhos utilizando condições diferentes obtiveram maior biodegradação desse surfactante.

- O sistema apresentou potencial para recuperar-se quando cessada a perturbação causada pelo aumento da concentração de LAS.

- O meio suporte foi seletivo para algumas populações bacterianas. 



\section{SUGESTÕES PARA TRABALHOS FUTUROS}

Com base na experiência adquirida durante este trabalho, sugere-se:

- Estudos sobre o efeito do crescimento da biomassa sobre a condições hidrodinâmicas de ASBBR.

- Utilização de configuração alternativa de reator bem como de outros materiais suportes para estudar a degradação do LAS.

- Avaliação do efeito da digestão do lodo sobre a degradação do LAS.

- Determinação da concentração ótima de co-substratos associados à degradação do surfactante. 



\section{REFERÊNCIAS BIBLIOGRÁFICAS}

ALMENDARIZ, F. J., MERÁZ, M., SOBERÓN, G., MONROY, O. (2001). Degradation of linear alkylbenzene sulphonate (LAS) in an acidogenic reactor bioaugmented with a Pseudomonas aeroginousa (M113) strain. Water Science and Technology, 44,183-188.

ANGELIDAKI, L., HAAGENSEN, F., AHRING, B. K. (2000). Anaerobic transformation of LAS in continuous stirred tank reactors treating sewage sludge. The CLER Review, 6: 32- 38 .

APHA/AWWA/Water Environment Federation. Standard Methods for the Examination of water and wastewater. 20th ed. Washington, DC, USA, 1998.

BERNA, J. L.; CAVALLI, L.; GUIDNER, A.; BATTERSBY, N.; FLETCHAER R.; SCHOWANEK, D.; STEBER, J. (2000). Assessment of the environmental relevance of anaerobic biodegradation of surfactant. The Cler Review, v.6, p. 4-17.

BORGES, A. C., Influência da estratégia de alimentação no desempenho do reator aneeróbio em batelada sequencial, contendo biomassa imobilizada. (2003). Dissertação. Escola de Engenharia de São Carlos, Universidade de São Paulo, São Carlos.

BORGES, A. C. , SIMAN, R. R., RODRIGUES J. A. D., RATUSZNEI, S. M., ZAIAT, M. FORESTI, E., BORZANI, W. (2004). Stirred anaerobic sequencing batch reactor containing immobilized biomass: a behavior study submitte to different fill times. Water Science and Technology, 49: 311-318.

CAMARGO, E. F. M., RATUSZNEI, S. M., RODRIGUES, J. A. D., ZAIAT, M., BORZANI, W. (2002). Treatment of low-strength wastewater using immobilized biomass in a sequencing batch external loop reactor: influence of the medium superficial velocity on the stability and performance. Braz. J. Chem. Eng., 19, 267-275.

CAVALLI, L., CASSANI, G., MARASCHIN, C. (1996). Structural elucidation of linear alkylbenzene sulfonate (LAS): biodegradation intermediates. The CLER Review, 2, 4-3.

CHERNICHARO, C. A. L. (1997). Princípios do tratemento biológico de águas residuárias. Reatores anaeróbios. Belo Horizonte: DESA-universidade Federal de Minas Gerais.

COHEN, Y. (2001). Biofiltration - the treatment of fluids by microorganisms immobilized into the filter bedding material: a mini review. Bioresource Technology, 77, 257-274.

COOK, A. M., HRSAK, D (2000). The complete degradation of LAS is becoming better understood with pure cultures of bacteria. The CLER Review, 6, 46-53.

CSERHÁTI, T., FORGÁCS, E., OROS, G. (2002). Biological activity and environmental impact of anionic surfactants. Environment International, 28: 337-348.

CUBAS, S. A., FORESTI, E. RODRIGUES, J. A. D., RATUSZNEI, S. M., ZAIAT, M. (2004). Influence of liquid-phase mass transfer on the performance of a stirred anaerobic sequencing batch reactor containing imobilized biomass. Biochemical Engineering Journal, $17: 99-105$. 
DENGER, K., COOK, A.M. (1999). Linear alkylbenzenesulphonate (LAS) bioavailable to anaerobic bacteria as a source of sulphur. J. Appl. Microbiol., 86:165-168.

DILLALO R., ALBERTSON O. E. (1961). Volatile acids by direct tritation. Journal WPCF, 33, 356-365.

DUARTE, I. C. S. (2006). Caracterização microbiológica da remoção e degradação de Alquilbenzeno Linear Sulfonado (LAS) em reatores anaeróbios com biofilme e células planctônicas. Tese de doutorado. Escola de Engenharia de São Carlos, Universidade de São Paulo, São Carlos.

DUARTE, I. C. S., MAYOR, M. S., OLIVEIRA, L. L., OKADA, D. Y., VARESCHE, M. B. A. (2007). Avaliação da degradação de detergente em reator anaeróbio operado em bateladas seqüenciais. In II Seminário do Projeto Temático “ Desenvolvimento de Sistemas Combinados de Tratamento de Águas Residuárias Visando a Remoção de Poluentes e a Recuperação de Energia e de Produtos dos Ciclos de Carbono, Nitrogênio e Enxofre". Escola de Engenharia de São Carlos, Universidade de São Paulo, São Carlos., Anais, p. 338-347.

DUARTE, I. C. S., OLIVEIRA, L. L., SAAVEDRA, N. K. D., FANTINATTIGARBOGGINI, F., OLIVEIRA, V. M., VARESCHE, M. B. A. (2008). Evaluation of the microbial diversity in a horizontal-flow anaerobic immobilized biomass reactor treating linear alkylbenzene sulfonate. Biodegradation, 19: 375-385.

FEITKENHAUER, H., MEYER, U. (2002). Anaerobic digestion of alcohol sulfate (anionic surfactant) rich wastewater-batch experiments. Part I: influence of the surfactant concentration. Bioresource Technology, 82, 443-453.

FERRER, J., MORENO, L. I., BERNA, J. L. (2002). Influence of innoculum source and bioavailability on the rate of anaerobic biodegradation of LAS homologues. In: VII Taller y Simposio Latinoamericano sobre Digestión Anaerobia, 2002, México, Anais, p. 277-284.

FRIEDL, G. F. (2008). Estudo de remoção de sulfato em biorreator operado em batelada e batelada alimentada seqüenciais, contendo biomassa imobilizada e utilizando agitação mecânica e "draft-tube". Dissertação. Escola de Engenharia de São Carlos. Universidade de São Paulo, São Carlos.

GAVALA, H., AHRING, B. K. (2002). Inhibition of the anaerobic digestion process by linear alkylbenzene sulfonates. Biodegradation, 13, 201-209.

GOUDAR, C., STREVETT, K., GREGO, J. (1999). Competitive substrate biodegradation during surfactant-enhenced remediation. J. Environ. Eng., 125, 1142-1148.

GRIFFITHS, R. I., WHITELEY, A. S., O'DONNELL, A. G. (2000). Rapid method for coextration of DNA from natural environments for analysis of ribossomal DNA and rRNA-based microbial community composition. Applied and Environmental Microbiology, 66, 5488-5491.

GUSMÃO, V. R. (2005). Caracterização microbiológica de cultura desnitrificante de reator anaeróbio horizontal de leito fixo utilizado na remoção de BTEX. Tese. Escola de Engenharia de São Carlos. Universidade de São Paulo, São Carlos. 
HOFER, R., ZSIGMOND, J., BUCHER, F. (1995). Chronic effects of linear alkylbenzene sulfonate (LAS) and ammonia on Rainbow Trout (Oncorhynchus mykiss) fry at water criteria limits. Wat. Res., 29, 2725-2729.

HOUSE, W. H., FARR, I. S. (1989). Adsorption of sulphonates from detergent mixtures on potassium kaolinite. Col. Surf., v. 40, p. 167-180.

JIMENEZ, L., BREEN, A., THOMAS, N., FEDERLE, T.W., SAYLER, G. (1991). Mineralization of linear alkylbenzene sulfonate by a four-member aerobic bacterial consortium. Appl. Environ. Microbiol., 57, 1566-1569.

KHLEIFAT, K. M. (2006). Biodegradation of linear alkylbenzene sulfonate by o two-member facultative anaerobic bacterial consortium. Enzyme and Microbial Technology, 39, $1030-1035$.

LEÓN, V. M., GONZÁlEZ-MAZZO, E., FORJA, J. M., GÓMEZ-PARRA, A. (2000). Identification of linear alkylbenzene sulfonate biodegradation intermediates in anoxic marine coastal sediments. The CLER Review, 6, 40- 45.

LÖBNER, T., TORÄNG, L., BATSTONE, D.J., SCHMIDT, J.E., ANGELIDAKI, I. (2005). Effects of process stability on anaerobic biodegradation of LAS in UASB reactors. Biotechnol. Bioengin., 89 (7), 759-765.

MAINTINGUER, S. I. (2004). Degradação anaeróbia de fenol sob diferentes condições nutricionais. Dissertação de Mestrado. Escola de Engenharia de São Carlos, Universidade de São Paulo, São Carlos.

MANOUSAKI, E., PSILLAKIS, E., KALOGERAKIS, N., MANTZAVINOS, D. (2004). Degradation of sodium dodecylbenzene sulfonate in water by ultrasonic irradiation. Wat. Res., 38, 3751-3759.

MIQUELETO, A. P., RODRIGUES, J. A. D., RATUSZNEI, S. M., FORESTI, E., ZAIAT, M. (2005). Treatment of easily degradable wastewater in a stirred anaerobic sequencing batch biofilm reactor. Water Research, 39, 2376-2384.

MIQUELETO, A. P. (2006). Polímeros extracelulares insolúveis (ESP) nos reatores anaeróbios operados em bateladas sequienciais: caracterização e fatores que favorecem a produção. Tese de doutorado. Escola de Engenharia de São Carlos, Universidade de São Paulo, São Carlos.

MOGENSEN, A. S., AHRING, B. K. (2002). Formation of metabolites during biodegradtion of linear alkylbenzene sulfonate in an Upflow anaerobic sludge bed reactor under thermophilic conditions. Biotechnol. Bioengin, 77, 483-488.

MOGENSEN, A. S., HAAGENSEN, F., AHRING, B. K. (2003). Anaerobic degradation of linear alkylbenzene sulfonate. Environ. Toxicol. Chem., 22 (4), 706-711.

MUYZER, G. D. E., WAAL, E. C., UITTERLINDEN, A. G. (1993). Profiling of complex microbial populations by denaturing gradient gel electrophoresis analysis of polymerase chain reaction-amplified genes coding for 16S rRNA. Appl. Environ. Microbiol., 59, 695-700. 
NIELSEN, A.T., LIU, W. T., FILIPE, C., GRADY, L., MOLIN, S., STAHL, D. (1999). Identification of a novel group of bacteria in sludge from a deteriorated biological phosphorus removal reactor. Appl. Environ. Microbiol., 65, 1251-1258.

OLIVEIRA, L. L. (2006). Influência do material suporte na degradação de Alquilbenzeno Linear Sulfonado (LAS) em Reator Anaeróbio. Dissertação de mestrado. Escola de Engenharia de São Carlos, Universidade de São Paulo, São Carlos.

OLIVEIRA, L. L., OKADA, D. Y., DUARTE, I. C. S., SILVA, E. L., VARESCHE, M. B. A. (2007). Estudo comparativo da remoção de alquilbenzeno linear sulfonado (LAS) em reatores de leito fluidificado com carvão ativado e argila expandida como materiais suporte. In II Seminário do Projeto Temático "Desenvolvimento de Sistemas Combinados de Tratamento de Águas Residuárias Visando a Remoção de Poluentes e a Recuperação de Energia e de Produtos dos Ciclos de Carbono, Nitrogênio e Enxofre". Escola de Engenharia de São Carlos, Universidade de São Paulo, São Carlos. Anais, p. 328-337.

ONO, A. F. (2007). Estratégias de operação de reatores aeróbio/anóxico operados em batelada seqüencial para remoção de nitrogênio de água residuária industrial. Dissertação. Escola de Engenharia de São Carlos, Universidade de São Paulo, São Carlos.

ORRA, A. A., RATUSZNEI, S. M., RODRIGUES, J. A. D., FORESTI, E., ZAIAT, M. (2004). Effects of feeding strategies on the performace of an anaerobic discontinuous reactor containing immobilized biomass with circulation system for liquid-phase mixing. Water Science and Technology, 49 (11): 303-310.

PATTERSON, D. A., METCALFE, I. S., XIONG, F., LIVINGSTON, A. G. (2001). Wet air oxidation of linear alkylbenzene sulfonate. 1. Effect of temperature and pressure. Ind. Eng. Chem. Res. 40 (23), 5507-5516.

PERALES, J. A., MANZANO, D., SALES, J. M. (1999). Linear alkylbenzene sulphonates: biodegradability and isomeric composition. Bull. Environ. Contam. Toxicol., 63, 94-100.

PINHO, S. C., RATUSZNEI, S. M., RODRIGUES, J. A. D., FORESTI, E., ZAIAT, M. (2004). Influence of the agitation rate on the treatment of partially soluble wastewater in anaerobic sequencing batch biofilm reactor. Water Research, 38, 4117-4124.

PINHO, S. C., RATUSZNEI, S. M., RODRIGUES, J. A. D., FORESTI, E., ZAIAT, M. (2005a). Feasibility of treating partially soluble wastewater in anaerobic sequencing batch biofilm reactor (ASBBR) with mechanical stirring. Bioresource Technology, 96, 517-519.

PINHO, S. C., RATUSZNEI, S. M., RODRIGUES, J. A. D., FORESTI, E., ZAIAT, M. (2005b). Influence of bioparticle size on the degradation of partially soluble wastewater in na anaerobic sequencing batch biofilm reactor (ASBBR). Process Biochemistry, 40: 3206-3212.

RATUSZNEI, S. M., RODRIGUES, J. A., CAMARGO, E. F. M., RIBEIRO, R., ZAIAT, M. (2003). Effect of feeding strategy on a stirred anaerobic sequencing fed-batch reactor containing immobilized biomass. Bioresource Technology, 90, 199-205. 
RIPLEY, L. E., BOYLE, W. C. and CONVERSE, J. C. (1986). Improved alkalimetric monitoring for anaerobic digestion of high-strength wastes. J. Water Pollut C Fed, 58, 406-465.

SANZ, J. L., CULUBRET, E., FERRER, J., MORENO, A., BERNA, S. L. (2003). Anaerobic biodegradation of linear alkylbenzene sulfonate (LAS) in Upflow anaerobic sludge blanket (UASB) reactors. Biodegradation, 14, 57-64.

SARTI, A., FORESTI, E. (2007). Aplicação de reatores anaeróbios operados em bateladas seqüenciais com filme fixo no tratamento e pós-tratamento de água residuária industrial rica em sulfato. In II Seminário do Projeto Temático “Desenvolvimento de Sistemas Combinados de Tratamento de Águas Residuárias Visando a Remoção de Poluentes e a Recuperação de Energia e de Produtos dos Cilcos de Carbono, Nitrogênio e Enxofre". Escola de Engenharia de São Carlos, Universidade de São Paulo, São Carlos., Anais, p. 236-246.

SCHÖBERL, P. (1989). Basic principles LAS biodegradation. Tenside Surfact Deterg., 26, 86-94.

SCOTT, M. J., JONES, M. N. (2000). The biodegradation of surfactants in the environment. Biochim. Biophys. Acta 1508 (1-2), 235-251.

SHCHERBAKOVA, V. A., LAURINAVICHIUS, K. S., AKIMENKO, V. K. (1999). Toxic effect of surfactants and probable products of their biodegradation on methanogenesis in an anaerobic microbial community. Chemosphere, 39 (11), 1861-1870.

SILVA, A. J. da. (2005). Biodessulfatação com posterior oxidação parcial do sulfeto em reatores operados em bateladas seqüenciais. Tese. Escola de Engenharia de São Carlos, Universidade de São Paulo, São Carlos.

SIMAN, R. R., BORGES, A. C., RATUZSNEI, S. M., RODRIGUES, J. A. D., ZAIAT, M., FORESTI, E., BORZANI, V. (2004). Influence of organic loading on an anaerobic sequencing biofilm batch reactor (ASBBR) as a function of cycle period and wastewater concentration. Journal of Environment Management, 72: 241-247.

SPEECE, R. E. (1996). Anaerobic Biotechnology for Industrial Wastewaters. Archae Press, Nashville Tennessee.

TORRES, P. (1992). Desempenho de um reator anaeróbio de manta de lodo (UASB) de bancada no tratamento de substrato sintético simulando esgoto sanitário sob diferentes condições de operação. Dissertação de Mestrado. Escola de Engenharia de São Carlos, Universidade de São Paulo, São Carlos.

VELA, J. F. (2006). Tratamento de esgoto sanitário em reator anaeróbio operado em bateladas seqüenciais e periodicamente aerado. Tese. Escola de Engenharia de São Carlos, Universidade de São Paulo, São Carlos.

ZAiAT, M. RODRIGUES, J. A. D., CAMARGO, E. F. M., BORZANI, W. (2001). Anaerobic sequencing batch reactors for wastewater treatment a developing technology. Applied Microbiology and Biotechnology, 55, 29-35. 